\title{
WestVirginiaUniversity
}

THE RESEARCH REPOSITORY @ WVU

Graduate Theses, Dissertations, and Problem Reports

1999

\section{Social and economic impacts of wild harvested products}

Brent Bailey

West Virginia University

Follow this and additional works at: https://researchrepository.wvu.edu/etd

\section{Recommended Citation}

Bailey, Brent, "Social and economic impacts of wild harvested products" (1999). Graduate Theses,

Dissertations, and Problem Reports. 3159.

https://researchrepository.wvu.edu/etd/3159

This Dissertation is protected by copyright and/or related rights. It has been brought to you by the The Research Repository @ WVU with permission from the rights-holder(s). You are free to use this Dissertation in any way that is permitted by the copyright and related rights legislation that applies to your use. For other uses you must obtain permission from the rights-holder(s) directly, unless additional rights are indicated by a Creative Commons license in the record and/ or on the work itself. This Dissertation has been accepted for inclusion in WVU Graduate Theses, Dissertations, and Problem Reports collection by an authorized administrator of The Research Repository @ WVU.

For more information, please contact researchrepository@mail.wvu.edu. 


\title{
SOCIAL AND ECONOMIC IMPACTS OF WILD HARVESTED PRODUCTS
}

\author{
Brent Bailey
}

\author{
Dissertation submitted to the \\ College of Agriculture, Forestry and Consumer Sciences \\ at West Virginia University \\ in partial fulfillment of the requirements \\ for the degree of
}
Doctor of Philosophy
in

Forest Resource Science

\author{
David E. Samuel, Ph.D., Chair \\ Steven J. Hollenhorst, Ph.D. \\ Edna L. McBreen, Ph.D. \\ Virgil Norton, Ph.D. \\ David G. Williams, Ph.D. \\ Division of Forestry
}
Morgantown, West Virginia
1999

Keywords: non-timber forest products, ginseng, conservation, West Virginia, Ghana Copyright 1999 Brent Bailey 


\section{ABSTRACT \\ SOCIAL AND ECONOMIC IMPACTS OF WILD HARVESTED PRODUCTS}

\section{Brent Bailey}

Wild harvested products (WHPs) are plants and animals, or parts of them, that are harvested from their native habitats for sale, trade, or personal consumption, by harvesters who are not employed by others to collect them. WHPs embody a range of economic, cultural, and social values held by residents of rural areas. However, the products' significance to harvesters and communities, and their conservation status, have until recently been little studied.

Assessments of social and economic impacts of WHPs on households and communities were conducted in West Virginia and West Africa. Interviews with harvesters, dealers, and resource managers revealed the range of products and extent of their impacts, and suggested strategies for managing products and integrating harvesters into management practices.

Harvesters in West Virginia collect over 2 dozen medicinal plants in a trade dominated by American ginseng (Panax quinquefolius). Grape vines and mosses are gathered by foragers for sale into the floral trade, both retail and wholesale. Wild edibles such as mushrooms and ramps (Allium tricoccum) are widely harvested but generally reserved for personal consumption rather than sale. Harvesters of medicinal plants are usually hunters of wild game, who seasonally shift their harvest activities in an annual cycle. Management of ginseng has relied on harvest data and dealer information to indicate the abundance and conservation status of wild populations. However, harvest data are more indicative of economic trends than they are of population status. Management practices used for hunting appear likely to apply to medicinal plants management.

A case study from Ghana, West Africa, describes the local-level impacts of a ban on access to forest products. Household surveys indicated the multiple benefits of WHPs, ranging from income generation to personal consumption, to gender- and age-based community roles. For communities closely tied to the landscape which were not participating fully in a cash economy, the creation of a national park affected forest use and household income, farming success, and diet. Community dynamics of forest loss brought about by export-driven economic development activities in the region of southern Ghana are discussed. 


\section{ACKNOWLEDGMENTS}

The list of people to whom I am indebted has grown long in 7 years. It's a pity that more than one name can't fit on a diploma.

Dr. David Samuel, my advisor and committee chair, consistently saw possibilities and opened doors to usher them toward reality. An older student with a family and job, lacking a funded project, interested in the social science of natural resource management, might have given pause to other wildlife professors considering retirement. Fortunately, Dr. Samuel is not one to pause. His enthusiasm, and an uncanny sense of when and how to guide or push, made this program work for me, even after his retirement.

Dr. Steve Hollenhorst, formerly of WVU's Recreation, Park, and Tourism Resources program (now at the University of Idaho), offered advice at the outset for fellowship funding. By virtue of his open door and proximity to my own office, he bore the brunt of impromptu questions and research dilemmas on more occasions than he'd bargained for as a committee member. Dr. Edna McBreen, former WVU Director of International Programs (now at University of Nebraska), Dr. Virgil Norton, formerly Chair of WVU Division of Resource Management (now at Upper Republican Natural Resources District in Imperial, Nebraska), and Dr. David Williams, Chair of WV Department of Public Administration, brought diverse perspectives to an interdisciplinary topic, and strengthened the final product considerably, even from a distance.

Colleagues with Conservation International in Washington, D.C. deserve special mention for their helpful interest and great flexibility in coordinating my ongoing professional responsibilities with an academic schedule. Chuck Hutchinson made the NTFP study in Ghana a reality, and Mari Omland showed that she is without peer in team leading and creativity. Kojo Mbir led me on a path into African village life through the NTFP study, and remains a trusted colleague and friend.

Colleagues have helped immeasurably to conceptualize approaches to the study of wild products and harvesters, and to provide much-needed advice. Marilyn Ortt pointed out the paucity of information about ongoing harvest activities in the Appalachian region. Martha Van der Voort's curiosity, clear judgment, and complementary ecological research provided balance, energy, and momentum as we launched our projects. Dr. Jim McGraw, WVU Department of Biology, was consistently generous with his time, intellect, and creativity. Dr. Carol Levin (Economic Research Service, USDA, Washington) offered a crash course in village-based survey methodologies. Additional help at critical points came from Dr. Andy Egan, now at University of Maine, and Drs. Rory Fraser, Strat Douglas, Bob Duvall, Dean Coble, and Rick Landenberger, all of WVU. Seminars with Dr. Joe Hagan provided critical research assessments.

Computer wizardry and data management were made possible thanks to Kathy Fletcher (WVU Academic Computing), who is yet to be stumped on any computing challenge, as well as Shawn Grushecky, Ann Steketee, Jerry Steketee, Jim Noonan, Ronnie Dumire, Gary Proch, Mark 
Bellamy, Monica Senus, and Susana Lopez.

My wife, Liz Cohen, and daughters Zannah and Lily have done more than their share of changing schedules and expectations to permit me to finish this long task... and have kept me aware of what's most important. Completion would not have been possible without the steadfast support of my mother-in-law, Laurie Cohen, who was willing to pitch in at home on a moment's notice. I've been keeping score, and I have a lot of catching up to do.

Finally, the open, friendly cooperation of numerous harvesters, dealers, and natural resource managers provided a wealth of knowledge, experience, and insight about wild harvested products that has not been adequately captured by academia. I am very grateful for their participation. I hope that by shedding light on the many facets of wild products, we can better conserve them.

Institutional support from a variety of sources was invaluable in carrying out this research. The Arlen G. and Louise Stone Swiger Doctoral Fellowship, administered through the WVU Foundation, provided three years of financial support for academic work. Funds from the WV Division of Forestry and the U.S. Agency for International Development (through Conservation International) supported field work. The Fausel Foundation, through the National Forest Foundation, provided critical funds to launch work on Wild Harvested Products, and contributions from the Mellon Foundation have supported analysis and outreach efforts. The U.S. Fish and Wildlife Service provided funds to coordinate a workshop for ginseng program managers from throughout the United States. Support from these multiple sources is gratefully acknowledged. 


\section{TABLE OF CONTENTS}

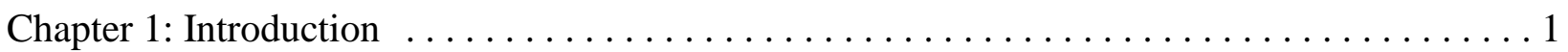

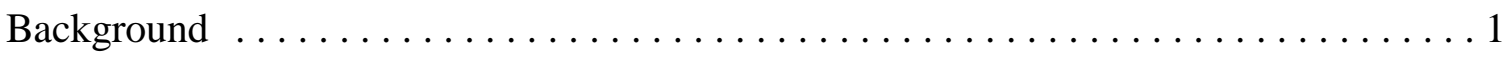

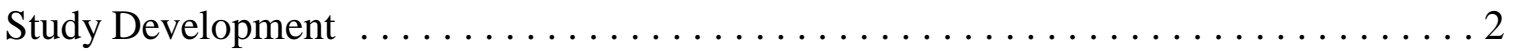

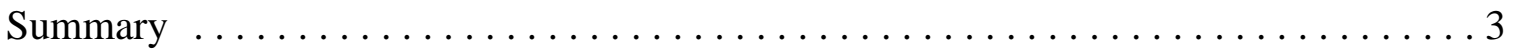

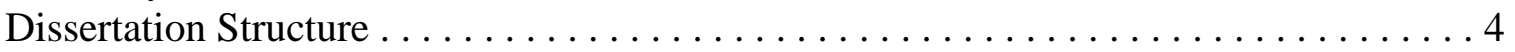

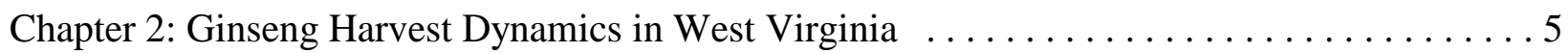

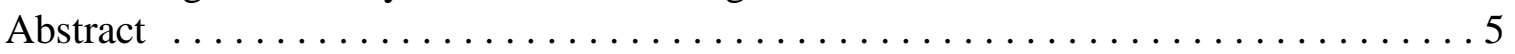

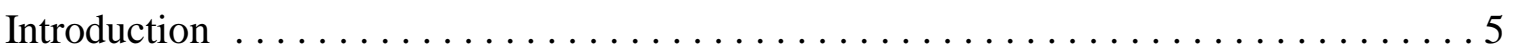

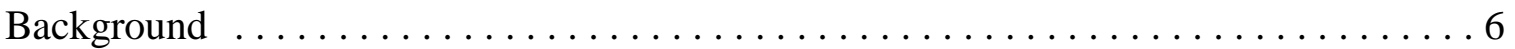

Data Sources and Methods .............................. 8

Harvest Variables: Availability and Intensity $\ldots \ldots \ldots \ldots \ldots \ldots \ldots \ldots \ldots \ldots \ldots \ldots \ldots$

Harvest Motivations: Economics and Culture $\ldots \ldots \ldots \ldots \ldots \ldots \ldots \ldots \ldots \ldots \ldots \ldots$

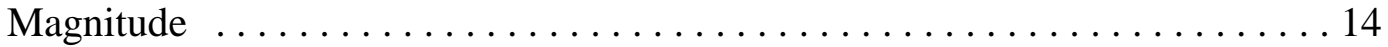

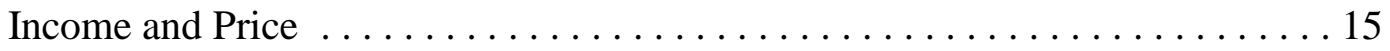

Lifestyle ..................................... 19

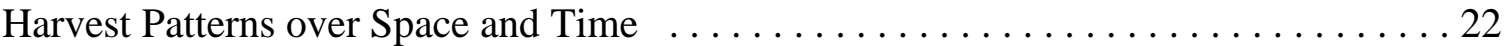

Geographic Distribution ............................. 22

"Long-term" Trends .................................. 24

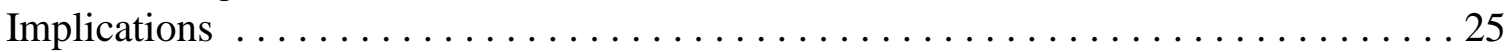

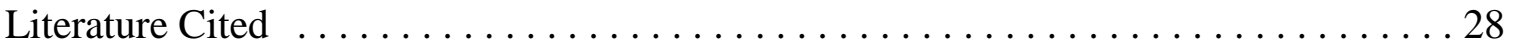

Appendix 2-A: Semi-structured Interview and Questions for Harvesters . . . . . . . . . 31

Appendix 2-B: Topics Regarding Wild Harvest Activities Included on the 1995 WVU

Social Indicator Survey of WV Households. .................. 33

Chapter 3: Medicinal Plants: Fair Game? Wildlife Management Tools for Plant Conservation 35

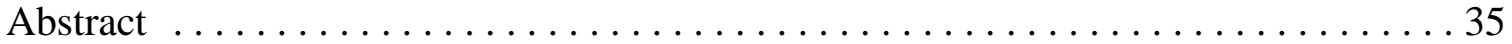

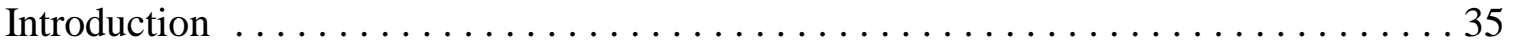

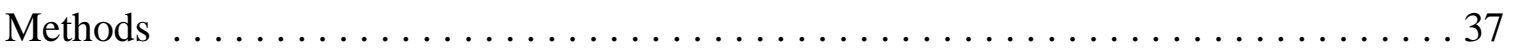

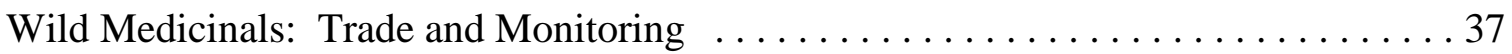

State Management Models . . . . . . . . . . . . . . . . . . . . . . . . 42

Wildlife Management Techniques: a Resource? . . . . . . . . . . . . . . . . 46

Conclusions ........................................ 49

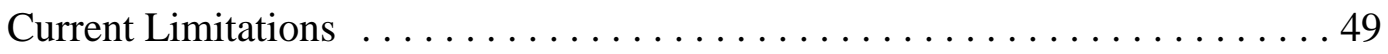

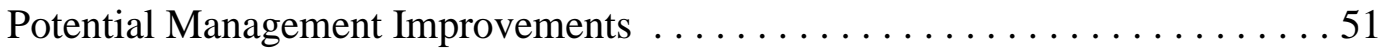

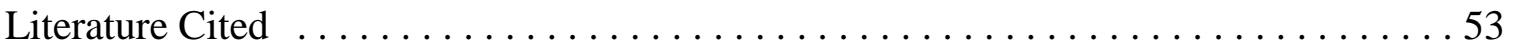

Appendix 3-A: Ginseng Workshop Questionnaire for State Program Managers . . . . 55 
Chapter 4: When Landscape Is Livelihood: Changes in Forest, Farm, and Food . . . . . . . 58

Abstract ........................................... 58

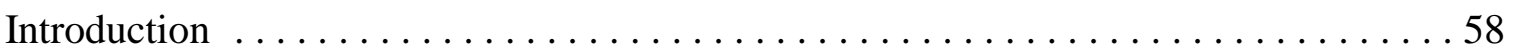

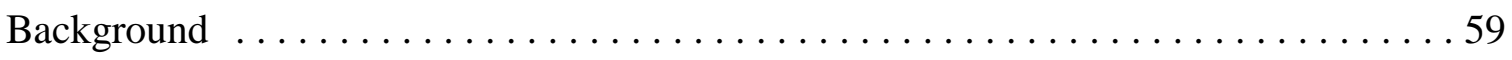

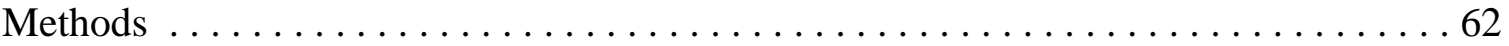

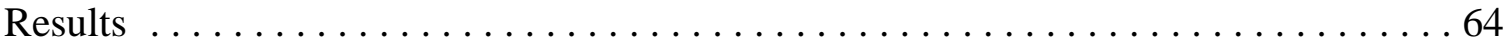

Household and Community Composition $\ldots \ldots \ldots \ldots \ldots \ldots \ldots \ldots \ldots$

Forests: Costs and Benefits ............................ 67

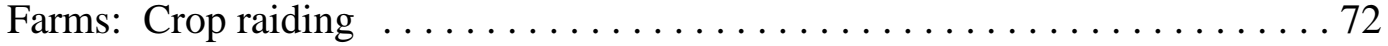

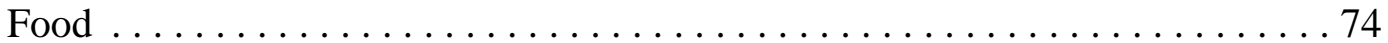

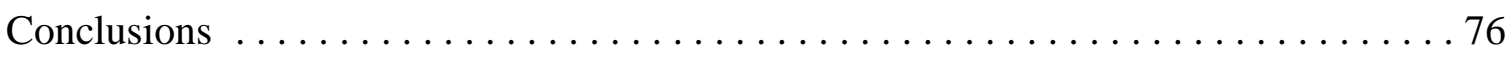

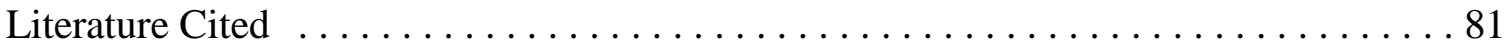

Appendix 4-A: Pre-Survey Data Sheet Non-timber Forest Products . . . . . . . . . . . 84

Appendix 4-B: Non-timber Forest Products Study $\ldots \ldots \ldots \ldots \ldots \ldots \ldots \ldots \ldots$ 


\section{LIST OF TABLES}

Table 2-1. Price per pound for dried ginseng root, West Virginia $\ldots \ldots \ldots \ldots \ldots \ldots$

Table 2-2. Harvest of wild products by West Virginia households . . . . . . . . . . . . 19

Table 3-1. Medicinal plants routinely traded in West Virginia, and approximate prices . . . . 39

Table 3-2. Status of ginseng management programs. $\ldots \ldots \ldots \ldots \ldots \ldots \ldots \ldots \ldots \ldots$

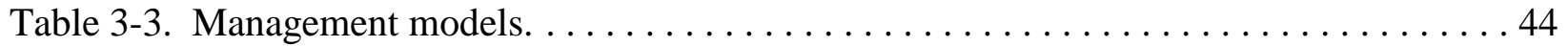

Table 4-1. Household and community characteristics in villages surrounding KCA . . . . . . 64

Table 4-2. Forest use and household economies in KCA . . . . . . . . . . . 68

Table 4-3. Adaptations to loss of access to forest products from KCA $\ldots \ldots \ldots \ldots$

Table 4-4. Plant product substitutes reported by $\mathrm{KCA}$ respondents $\ldots \ldots \ldots \ldots \ldots \ldots \ldots$

Table 4-5. Bushmeat substitutes reported by KCA respondents $\ldots \ldots \ldots \ldots \ldots \ldots \ldots \ldots$

Table 4-6. Farm-related characteristics in environs of KCA $\ldots \ldots \ldots \ldots \ldots \ldots$

Table 4-7. Incidence of crop damage to farms by elephants as reported by farmers $\ldots . . .74$

Table 4-8. Food and dietary characteristics in environs of KCA $\ldots \ldots \ldots \ldots \ldots$

Table 4-9. Household and community impacts of loss of access to forest resources . . . . . 77 


\section{LIST OF FIGURES}

Fig. 2-1. Annual ginseng harvest for selected states $\ldots \ldots \ldots \ldots \ldots \ldots \ldots \ldots \ldots \ldots$

Fig. 2-2. Ginseng harvest variables $\ldots \ldots \ldots \ldots \ldots \ldots \ldots \ldots \ldots \ldots \ldots \ldots \ldots \ldots$

Fig. 2-3. Percent of ginseng volume by frequency of sales $\ldots \ldots \ldots \ldots \ldots \ldots \ldots \ldots$

Fig. 2-4. WV ginseng sales by week of season, $1994 \ldots \ldots \ldots \ldots \ldots \ldots$. . . . . . . . . 17

Fig. 2-5. A forager's calendar of wild harvested products. $\ldots \ldots \ldots \ldots \ldots \ldots \ldots \ldots$

Fig. 2-6. Range of pounds of ginseng harvested from WV counties, $1994 \ldots \ldots$. . . . . . 23

Fig. 2-7. WV ginseng harvest in relation to unemployment and drought . . . . . . . . 24

Fig. 3-1. WV ginseng sales, unemployment, and drought $\ldots \ldots \ldots \ldots \ldots \ldots \ldots$

Fig. 4-1. African continent, with Ghana enlarged . . . . . . . . . . . . . . . . 59

Fig. 4-2. Satellite mosaic image of southern Ghana $\ldots \ldots \ldots \ldots \ldots \ldots \ldots \ldots \ldots \ldots \ldots$

Fig. 4-3. Kakum Conservation Area, Ghana . . . . . . . . . . . . . . . . . . 60

Fig. 4-4. Distribution of settler families arriving since 1959, Kakum Conservation Area . . . . 66

Fig. 4-5. Settler arrivals to Kakum Conservation Area since 1959 . . . . . . . . . . . . . 67

Fig. 4-6. Access to alternative forest patches around KCA, $1994 \ldots \ldots \ldots \ldots$. . . . . . 69

Fig. 4-7. Actual and preferred dietary meat protein among KCA respondents, $1994 \ldots$. . . . . 76 


\section{CHAPTER 1}

\section{INTRODUCTION}

\section{BACKGROUND}

Wild harvested products are defined as those plants and animals, or parts of them, that are hunted, gathered, or foraged from their native habitats, by individuals who are not salaried or employed by others to pursue the products. Wild harvested products are collected for income, trade, or personal consumption around the world, from a variety of habitats: forests, aquatic systems, grasslands, and coastal zones, among others. Wild game, medicinal plants, floral items such as vines or mosses, materials for basket making and other crafts, mushrooms, non-cultivated fruits, shells, and household items used for shelter or tools, are examples of wild harvested products.

The harvest of wild products is often motivated by the potential for economic gain. The intensity with which wild harvested products are pursued is related to such economic parameters as harvesters' economic needs, alternative employment opportunities, time available for harvest, and prices offered for products. However, social and cultural attributes frequently define the context in which the harvest occurs, and in some cases may override economic motivations in importance. Family tradition, values that emphasize independence and self-sufficiency, a natural resource-dependent lifestyle, and seasonal or cyclical ritualized forays imbue the harvest of wild products with meaning and continuity. Furthermore, the habitats in which the harvest occurs, and in many cases the products themselves, often form a backdrop for stories, songs, and symbolism in the communities and ethnic groups that undertake wild harvests.

As with any wild product that is subject to harvest pressure, collection by humans has an impact on population size and reproductive success. For widespread, abundant species with adequate reproductive strategies, impacts of collection may not pose a challenge to reproductive success or sustainable populations: fruits and nuts, wild rodents, and grape vines are among those that 
appeared to withstand current levels of harvest pressure in this study. However, the status (abundance and resilience) of many species is often not known, and information on harvesters and harvest pressure is unavailable. In the absence of this information, efforts to manage or conserve the species, or to ensure the long-range viability of collection by harvesters, will be more dependent on trial and error than on strategies that focus deliberately on known causes and effects of harvest dynamics.

\section{STUDY DEVELOPMENT}

The purpose of this study was to identify the range of products and roles they played in communities in 2 different study sites, and to identify key variables that can guide conservation and management. In Ghana, West Africa, the conversion (by the national government) of a forested area from classification as a forest reserve to a national park resulted in the prohibition of local villagers' access to non-timber forest products that were significant to their livelihoods. The resulting outcry led Conservation International, a non-profit, U.S.-based group, and its donor, the U.S. Agency for International Development, to sponsor an assessment of the impacts of the park's establishment on local livelihoods. The assessment, conducted as part of this doctoral research, focused on one particular protected area and local communities. However, when put into the context of Ghana's deforestation and landscape changes throughout the West African region, the cumulative impacts of trends in landscape conversion raise concerns about the social functions and contingency survival strategies for rural villages throughout Ghana's forest zone.

A chance conversation about the African study with a botanist from Ohio suggested that similar research was needed in the eastern U.S., and particularly in the central Appalachians, where little more than anecdotal information existed about wild harvested products. As an example, she pointed to a cursory study of a block of counties in southeastern Ohio which lies partially within the Wayne National Forest totaled timber receipts in 1990 from the area of $\$ 61,000$; sales of ginseng for the same area totaled $\$ 700,000$ (E. Jaquart, pers. comm.). However, the forest was managed for timber, employed no botanists, and had limited information on ginseng abundance 
in the forest, or the harvesters who collected it.

Literature review and conversations with national and state resource managers revealed that the Ohio example was not unique in West Virginia. As a corollary to the Ghana study, a West Virginia component was undertaken. This was intended as exploratory research, focused to provide a broad-based picture of the current status of harvesters and wild products in the state, and to suggest directions for future research. Lacking systematic sampling frames for identification of harvesters and harvest sites, the study pursued qualitative information as a means of defining the parameters that drive the harvest activity. Cooperation with government agencies, particularly the U.S. Fish and Wildlife Service and the WV Division of Forestry, were essential to undertaking the project, and ultimately key to its success.

\section{SUMMARY}

The Ohio example points out key parameters that shaped the picture of wild harvested products in both study sites, and contributed to the specific information sought in the course of interviews. First, an unorganized economic activity such as harvest of wild products is often overlooked, and little valued, by government agencies, though it may be commonly known to occur as a "traditional" activity. Second, harvesters of wild products are rarely known to resource managers. They are not represented by an industry group; they conduct their harvest stealthily, since drawing attention to their activity might invite competitors; they are not vocal with their elected representatives; and they often are economically and politically marginalized. Third, access to land is a key variable. Most wild products encountered in this study grow over large ranges, and harvesters cross multiple boundary lines in pursuit of them. Few harvesters own sufficient land to meet their harvesting needs; indeed, land ownership was limited among most harvesters. Public lands offer harvesters easier access to products, but the inability of harvesters to control access provides them with incentives to harvest with immediate gratification in mind, rather than plan to harvest smaller quantities over a longer time period. Finally, wild products have been little studied: basic information about their abundance, distribution, ecology, and reproductive strategies is often unavailable. 
This set of characteristics emerged during research in both sites, and suggests that despite such major differences as tropical vs. temperate zones, "developed" vs. "developing" economies, and different economic scales and frameworks, common dynamics exist that can unify approaches to understanding wild products and harvesters, and managing the activity.

In West Virginia, wild harvested products studied fell largely into 3 categories: medicinal plants, items for the floral trade, and wild edible plants. Wild game (animals) were excluded, since game management and hunting have received long-standing attention from the state's Division of Natural Resources. Specialty items for the craft trades, such as decorative woods, dyes, and basket materials, were not sufficiently widespread among collectors to warrant a focus in this study. The collection and sale of bait for fishing occurs widely, but was deemed difficult to include in this study due to its dispersed market chains. However, any of these products merits further attention.

\section{DISSERTATION STRUCTURE}

The far-flung nature of field sites, different bodies of literature that pertain to them, and uneven levels of information available created an apples-and-oranges set of knowledge for this doctoral research. The doctoral committee therefore agreed that for purposes of this dissertation, three articles prepared for publication would be deemed an appropriate body of work. Chapters 2,3, and 4 are those articles, which will be submitted to journals after submission of the dissertation. Though they are not formally linked, readers will see that common threads and lessons run through them.

This structure leaves work still to be done, intended to be prepared for future publications. This includes an expanded assessment of the cultural roles of wild harvested products; an exploration of cross-cultural lessons that define approaches to wild harvested products; specific information on the active trade in wild mosses from the highlands of West Virginia; and further research on wild edibles, particularly mushrooms and ramps, in the Central Appalachians. 


\title{
CHAPTER 2
}

\section{GINSENG HARVEST DYNAMICS IN WEST VIRGINIA}

\begin{abstract}
The volume of wild American ginseng (Panax quinquefolius L.) harvested annually in West Virginia is determined by the species' availability and the intensity of harvest effort. Social, cultural, and economic variables are dominant factors influencing availability and intensity, and thus affect the population dynamics of the species. Harvesters are motivated by income potential, especially during times of economic hardship. However, they are also influenced by non-economic factors such as family tradition, a pride in self-sufficiency, and a natural resource-based lifestyle that includes hunting of wild game and gathering of wild foods. Harvests vary by region of the state, and from one year to the next. Harvest levels do not necessarily reflect abundance of the species in the wild.
\end{abstract}

\section{INTRODUCTION}

Despite an extended history supporting rural families through international trade, the harvest of wild American ginseng (Panax quinquefolius L.) has rarely been studied. The clandestine nature of the harvest activity, the veil of secrecy with which diggers conceal the locations of their foraging, and the anonymity of the harvesters make information about harvest dynamics relatively inaccessible. The plant's perennial habit and economic value are also deterrents to the study of wild populations, since documenting its multi-year life history requires time, and often entails a race to collect data before harvesters collect the plants (see Anderson et al. 1993, Lewis 1984, Lewis and Zenger 1982).

In West Virginia, near the center of the species' range, the harvest and sale of wild American ginseng is commonly viewed as part of the cultural fabric of rural communities (Hufford 1997), and its economic value has been anecdotally noted by various observers of the forest and its commodities (Millspaugh 1892, Price 1960, Strausbaugh and Core 1979). Indeed, if forest export products were evaluated for their longevity as commodities, consistency of harvest, and widespread economic impact on rural families, ginseng would probably rank near the top among forest commodities from the state and the Central Appalachians.

Annual harvests affect not only human communities; they also affect ginseng's reproductive potential and abundance in the wild (Nantel et al. 1996). Thus the human influence emerges as a 
significant element of the population dynamics of wild American ginseng. Understanding the impact of harvest on human communities and on wild populations is therefore key to effective management and conservation of the species. This paper identifies variables that determine patterns of harvest and trade of wild American ginseng, and examines the links between social, cultural, and economic factors and management of the species in the wild.

\section{BACKGROUND}

American ginseng is an herbaceous perennial plant native to woodlands of eastern North America, originally ranging from Québec to northern Florida, and west to Manitoba, Oklahoma, and Arkansas (Fernald 1950, Gleason 1963, Britton and Brown 1970, Fountain 1986). Its use as a medicinal plant by Native Americans has been documented (Goldstein 1975, Moerman 1986), but it is unclear whether widespread use in North America predated the commercial trade (Carlson 1986). The species acquired economic value as an export product in 1720, when its roots were shipped by a Jesuit priest from Ontario, Canada, to China (Carlson, 1986). Its reputation in the Orient as an aphrodisiac, tonic, and life-prolonging drug (Schorger 1969, Goldstein 1975) persists: Over $85 \%$ of wild ginseng roots harvested annually from the U.S. are exported to Hong Kong (Hensley et al. 1979, Robbins 1998).

Nearly three centuries of harvest have not eliminated American ginseng from the wild, though its harvest is forbidden in Canada due to scarcity (Nantel et al. 1996) arising from habitat destruction and over- harvesting (Charron and Gagnon 1991). U.S. records indicate declines in the exported wild harvest. From 1821 to 1899 , an average 381,000 pounds of roots were exported annually (Carlson 1986); annual exports of wild ginseng root from the United States for the years 1989 through 1996 averaged just over 128,000 pounds (USFWS 1997). Harvesters of the root as well as botanists have noted that the plant is less and less common throughout its range in West Virginia (Fernald 1950, Strausbaugh and Core 1979), but neither baseline data nor long-term studies of wild ginseng abundance and distribution exist to bear this out.

Although wild ginseng roots command the highest prices on international markets, a variety of alternative production methods have been developed to satisfy market demands. Exports of 
cultivated ginseng exceed the volume of wild root exported by 13 times (Robbins 1998).

Wisconsin's cultivation of ginseng started in the early 1900s, and is a major revenue producer for Marathon County (Carlson 1986). Close to $95 \%$ of the U.S. cultivated ginseng crop comes from Wisconsin, and is exported; $90 \%$ of the exported cultivated root goes to Hong Kong (Robbins 1998). However, because cultivated roots lack the shape and quality of wild roots, they are believed to be less potent, and therefore currently sell for $10 \%$ or less of the price of wild roots. Two alternative production methods which achieve "intermediate" grades of ginseng root more closely resembling the wild product -- and therefore bring higher prices than conventionally cultivated roots -- include wild-simulated and woods-grown ginseng (WVU undated).

The wild ginseng root that is harvested and sold is a thick storage organ for starch, attached to a rhizome ("neck"), an underground stem which annually sends up an aerial shoot bearing leaves. The root is firm and fibrous. Small lateral or adventitious roots grow from the primary root; three to four years after the primary root is established, at least one adventitious root often enlarges to resemble the primary root, creating a fork that can take on the appearance of legs, or a human body (Anderson et al. 1993). The plant's principal mode of reproduction is sexual; fragmentation of the rhizome may result in asexual reproduction, but this is believed to be very rare (Lewis and Zenger 1982). Seven or more years are generally required for a plant to reach sexual maturity, at which time it flowers and sets seed. Seed production generally increases as a plant ages. American ginseng can live for 50 or more years (Lewis and Zenger 1982).

The harvest of the ginseng root removes an individual plant's reproductive potential from a population, and is certainly more destructive to a population than harvests limited to leaves, fruits, or other plant parts sought from other species. Recovery of a population is thus dependent on the germination of seeds already in the leaf litter, or left by the harvester. Because seeds require an average of 20 months to germinate (Lewis and Zenger 1982), an area harvested of ginseng plants in one year may have a population of new seedlings appear two seasons later. Harvest in most states is restricted to "mature plants" (characterized by three or more "prongs", or leaves). Regulations in most states also require that any seeds on plants to be harvested must be red (indicating ripeness), and must be planted on the site from which the parent plant is dug. 
International trade in American ginseng led to its being listed on Appendix II of the CITES (Convention on International Trade in Endangered Species) Treaty, as a species that requires monitoring in the wild to ensure that harvest levels cause no detriment to the species' survival. The U.S. Fish and Wildlife Service (USFWS) represents the U.S. government at CITES negotiations, and in 1978 issued requirements and guidelines to states regarding the collection of ginseng harvest data (Federal Register 1978). Summary data from each state are submitted annually to the USFWS, forming the basis for federal management of ginseng as a species of concern. If states are unable to prove that harvest levels cause no detriment to wild populations of the species, trade in wild ginseng root could be suspended range-wide or in selected states by federal rule.

\section{DATA SOURCES AND METHODS}

In order to evaluate the dynamics of the ginseng harvest in West Virginia, qualitative, guided interviews with 62 diggers, buyers, and resource managers were conducted from 1993 to 1996 (Patton 1990). Motivations, patterns, and practices associated with ginseng harvest were the focus of interviews (see Appendix 2-A). Approximately 110 face-to-face interview hours were completed. Telephone and mail follow-ups added to and refined the information. Interviews with diggers varied considerably in length, depending on the cooperative nature of the respondent, but ranged from 1 hour in a visit with one respondent to repeated visits and outings with another that totaled 16 hours. Comments and observations made by diggers, many of which are quoted in this paper, directed paths of inquiry and subsequent data analysis.

No lists of diggers exist in West Virginia from which a statistically random sample could be selected for interviews. The pool of respondents developed as a snowball sample: Diggers were identified through references from dealers, or friends, or friends of friends (Babbie 1995). Indeed, the sample was generated through such circuitous and serendipitous circumstances that haphazard, but not statistically random, would accurately describe the pool of respondents that eventually formed. All introductions to diggers were made by a cooperative intermediary, who could attest that the interviewer was not linked in any way to a revenue agency, law enforcement division, or root-digging competitor. Confidentiality of respondents was assured at the outset of 
each digger interview.

West Virginia's Division of Forestry (DOF) is the state agency that monitors the ginseng harvest and collection of harvest data. DOF provided figures for annual ginseng harvest totals by county since 1978, the year USFWS regulations were issued. The DOF also agreed to allow access to records of 1994 ginseng sales, submitted every 30 days to the state by dealers. Nearly 23,000 reported transactions took place in West Virginia that year; all reported transactions were entered into a database which included the digger's name, the date of sale, the weight of dry and green root sold, and the county from which the roots were reportedly dug. These data were used to derive average weight per transaction, the range of weights sold, ginseng production by county, and the timing during the season of transactions. Dealer records submitted to DOF on standardized state forms were most often hand-written.

Once the principal data were entered and alphabetized by diggers' last names, it became apparent that a large percentage of the nearly 23,000 sales were made by "repeaters," diggers who sold multiple times; the actual number of diggers is much less than the number of transactions. Returning to the handwritten data sheets, duplicate entries of diggers' names were searched for corroborating information which would clarify whether the dozen entries under the same name, such as "Bob Jones," represented 12 sales by the same person, or 12 different individuals with the same name, or some combination of the two. Some dealers filled out forms completely, including addresses and (optional) social security numbers. In these cases, comparing such variables permitted easy identification of repeat-sales diggers. However, other dealers filled out forms incompletely, limiting the possibility of confirming "repeaters." Thus for the hypothetical case of "Bob Jones," analysis could confirm that there were at least three individuals (with distinct social security numbers or addresses) with the same name: One sold ginseng once, another sold twice, and the third sold five times during the season. The remaining 4 transactions by "Bob Jones" could not be confirmed, however, due to lack of corroborating identifiers. They could represent 4 additional individuals with the same name, or they could correspond to the already-known individuals. In such cases, the 4 transactions were construed to represent 4 separate individuals. It was also possible to confirm in some cases that sales made to dealers by 
"Robert Jones" were by the same individual reported elsewhere as "Bob Jones." Though the incomplete data made the analysis imperfect, it did permit a rough estimate of the maximum number of diggers, and a low (minimum) estimate of the number of individuals who sell more than once.

A set of questions regarding the harvest of wild products was included on a 1995 telephone survey of social indicators conducted by West Virginia University's Survey Research Center, reaching $922 \mathrm{WV}$ households (see Appendix 2-B). This was used to estimate the extent of harvest of wild products among households in the state. The Social Indicator Survey is conducted annually, and includes core questions relating to respondents' incomes, occupations, education, and other demographic variables (Keith et al. 1996). The random sample was based on random digit dialing techniques. Key variables were cross-referenced with U.S. Census data to verify the sample's representativeness.

\section{HARVEST VARIABLES: AVAILABILITY AND INTENSITY}

The harvest of wild ginseng varies considerably from year to year and state to state (see Fig. 2-1). A complex set of ecological and socioeconomic variables are hypothesized as factors influencing the level of harvest (Fig. 2-2), and in some cases these variables influence each other. The magnitude of harvest in any given year is based on 2 principal factors: the availability of plants for harvest and the intensity of effort that harvesters put forth.

Availability of plants depends on their abundance -- whether they exist at all, and in what quantities -- and on their apparency -- whether the leaves and/or berries are sufficiently evident to be detected by a harvester. Abundance of plants is affected by suitability of habitat (slope, aspect, soils, shade), environmental conditions (temperature and precipitation), size and age of populations, and the incidence of prior harvest. An area of otherwise optimal habitat, environmental conditions, and population parameters may not have ginseng due to prior extraction. As one lifelong harvester explained, "People who can't find ginseng usually don't know where to look. And if they look where I've been, they're not going to find any either." Abundance on a site or within a population will vary naturally over a period of several years, as 
seeds in the soil germinate and plants mature to become reproductive.

However, it is also possible that living roots may be abundant, while aboveground herbaceous

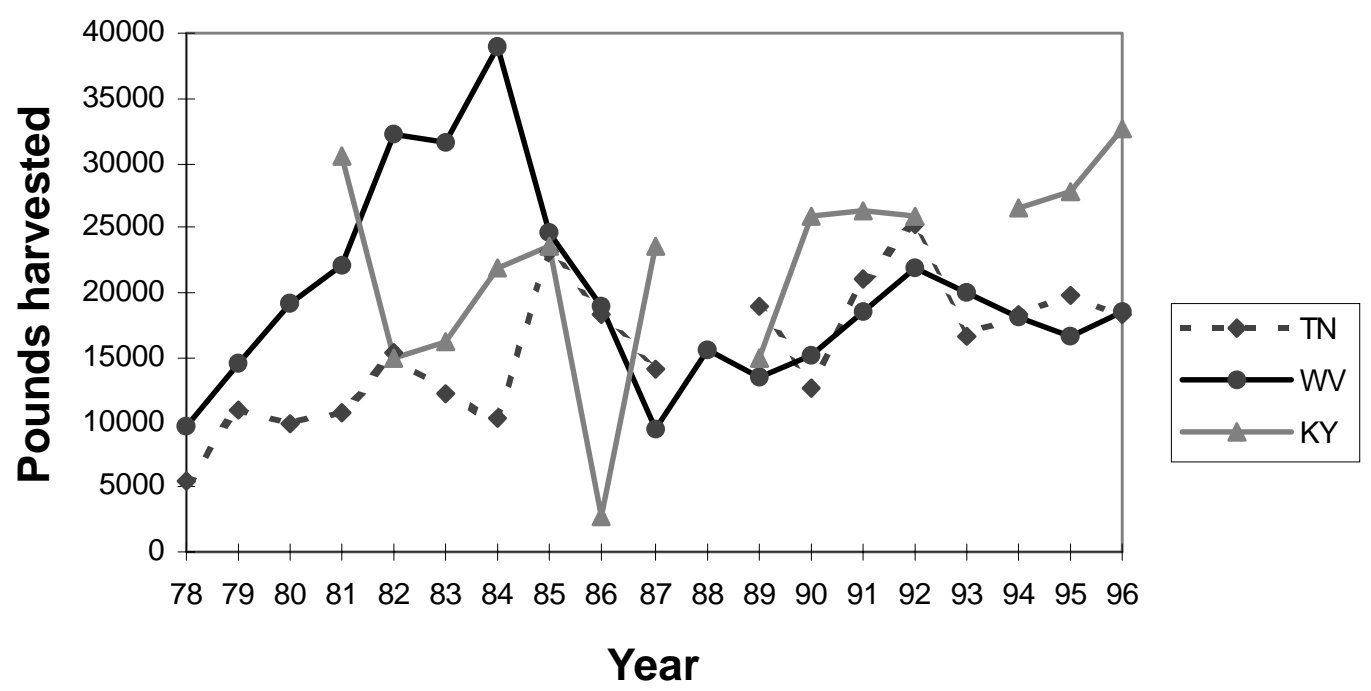

Fig. 2-1 Annual ginseng harvest for selected states.

vegetation may not be apparent to harvesters. Apparency is influenced by multiple factors. The mystique of the plant often entered into respondents' comments: "Ginseng won't ever go extinct, because it hides itself some years," reported a buyer. Factors influencing the species' tendency to "hide," or elude harvesters, include late spring frost or early fall frost, or both, which can cause herbaceous material to die back to the ground without killing the root, but rendering it undetectable. Drought may limit growth and development of stems and leaves (and therefore apparency), or result in early dieback. A drought may create conditions for wildfires during the ginseng growing season, killing back above-ground vegetation. Deer and other mammals reportedly browse ginseng leaves, leaving the root to escape detection by harvesters. Some harvesters report clipping back vegetation early in the summer to prevent other harvesters from finding and digging plants before the discoverers return in the fall. One study of ginseng populations concluded that dormancy in ginseng results from extreme periodic environmental 


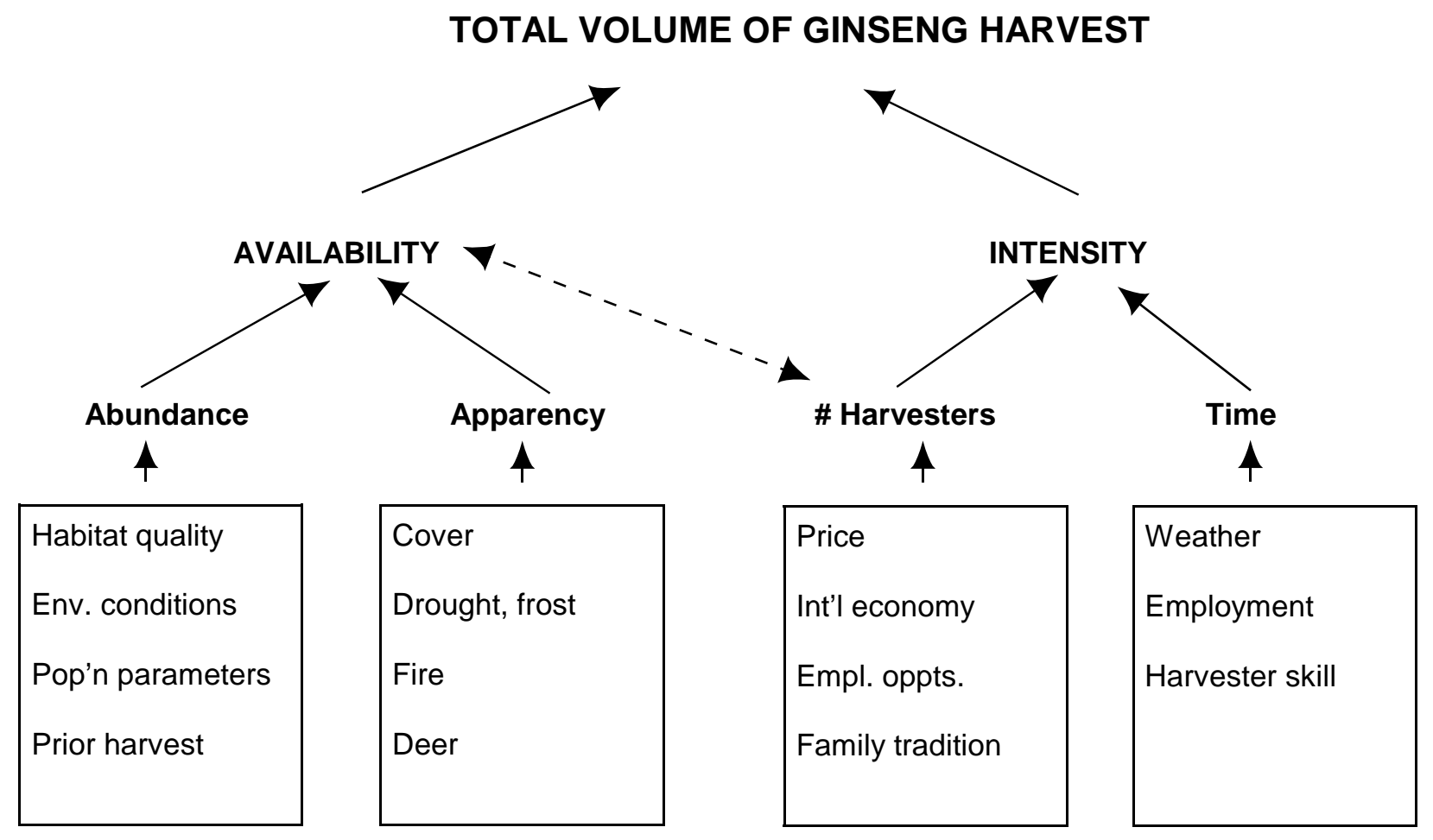

Fig. 2-2. Ginseng harvest variables.

variables, or predation, rather than as a cyclical characteristic of populations or individuals (Lewis and Zenger 1982). There are other factors which may influence apparency: Habitats traditionally viewed as "sub-optimal" may be ignored by seasoned harvesters, but can harbor populations. And vegetative cover -- especially dense patches of nettles, or thorny canes of berry bushes, which frequently populate old clear cuts -- serves to hide harvestable plants as well.

Intensity of effort by harvesters is driven both by the number of harvesters engaged in the search, and the amount of time harvesters invest in the hunt. Harvest intensity may be expressed in terms of number of hours or person-days spent searching for ginseng, distance covered in the search, or the number of ginseng diggers motivated to join the search. Intensity of harvest effort is driven by several factors. One of them is price: "I wasn't much interested in digging a lot of root until the price got up to 350 [dollars per pound of dried root]", claimed a harvester. "With the price so high, you get all kinds of folks who want to start digging 'sang," reported another. "Hell, my wife came out with me this year for the first time," a long-time digger stated. 
However, price is not a consistent motivator, since it varies from dealer to dealer and throughout a season.

Alternative employment (income) opportunities play a significant role in determining harvest intensity. "It's not really worth your time to do this, at least on an hourly basis [regardless of price per pound]," explained a dealer. Indeed, dividing ginseng revenue by the number of hours spent foraging for roots yields less than minimum wage for most diggers. But if other jobs are not available, ginseng provides short-term, albeit limited, income. "I've been on disability for a while now, so I get into the woods more often," said a digger. Alternative employment opportunities may also mean that diggers simply have less time to harvest wild roots. Rural communities in West Virginia that are largely dependent on coal and timber extraction are often characterized by fluctuating periods of employment. "I didn't get out [for ginseng] as much this year since I got hired back," one logger-respondent explained. As a traditional late summerautumn activity, many diggers are motivated to forage for ginseng at some point, though their foraging frequency may be constrained by external factors such as employment. Thus low annual harvest figures summarized by the state do not necessarily indicate low abundance of wild ginseng, nor fewer diggers overall participating in the harvest.

Harvest intensity and availability affect each other, and in some cases are affected by the same variables. For instance, weather can be a determinant of harvest intensity, though its impact is somewhat localized. Diggers recall seasons that were too stormy, or too cold too soon, to enjoy the search or invest much effort in it. Locally, this can favorably affect abundance for subsequent years. Similarly, diggers mention summers that were so hot and dry that "I knew there wouldn't be much to find if I did go out" in the fall. Wildfires may eliminate vegetation in the understory, or keep 'sangers' out of the woods altogether. Thus a lack of availability, whether presumed or observed, can result in reduced effort, or intensity, and leave ginseng roots to grow in another season. The interaction of intensity and availability also can reduce harvests of subsequent years: A year of successful harvest resulting from high availability of plants and intense harvest effort reduces the amount of ginseng available from the same area the next year. 


\section{HARVEST MOTIVATIONS: ECONOMICS AND CULTURE}

\section{Magnitude}

Annual records of ginseng sales - maintained by all states with ginseng programs approved by the U.S. Fish and Wildlife Service -- can be analyzed to assess the role that ginseng plays in rural communities and in the state as a whole. Combined with interview-based information, a fuller picture of ginseng harvest motivations can be derived, which in turn provides information for ginseng management.

In West Virginia, nearly 23,000 sales of ginseng from diggers to dealers occurred during the 1994 harvest season. Dried roots were sold in 21,361 transactions, more than 10 times the number of transactions in which green roots were sold $(2,010)$; in some cases, diggers sold both dried and green roots during the same transaction. Dealers' 1994 reports, submitted to the state, indicated that 17,348 pounds of dried roots were bought from diggers, compared to 1,387 pounds of green. The average annual volume of wild ginseng harvested in-state and sold from 19781996, according to state records, was 19,943 pounds. The mean weight of dried ginseng sold in each 1994 transaction was 12.99 ounces; at a \$350/lb price (the average price that year for a pound of good-quality dried root), one such sale would have brought the digger $\$ 275$.

Roots that have been properly dried (two weeks at room temperature, on a rack) bring the highest prices, especially if they are sold in large quantities (close to a pound). Roots that are green, or not dried completely, will be purchased by dealers for a fraction of the dried-root price. According to dealers, dried roots weigh $25-33 \%$ of their green weight. Attempts to hasten drying time -- such as in an oven or microwave -- generally affect the color and appearance of roots, making them more difficult to sell and resell. Improperly dried roots will either be rejected by dealers outright or purchased at minimal prices.

An analysis of 1994 transactions showed that many diggers sold more than once; the 22,958 transactions were actually conducted by a maximum of 16,471 diggers. Of all sales, 13,322 $(58 \%, \mathrm{n}=22,958)$ were transactions by one-time sellers for that season (or only identifiable as such; incomplete records precluded identification of some of these sellers as "repeaters") . At 
least 9,636 sales ( $42 \%$ of the total number of transactions) were conducted by a minimum of 3,149 individuals, who sold more than one time during the season. Diggers selling more than once thus accounted for at least $19 \%$ of all diggers. Those who sold twice totaled 1,920 individuals (11.66\%); and three-time sellers numbered 575 (3.49\%). In terms of volume, singlesales diggers accounted for $62.69 \%$ of all pounds sold $(n=22,958)$ (see Fig. 2-3). Frequency of sales does not necessarily indicate that more pounds of root were dug by an individual: The digger who sold the most times (58) sold many small roots, which summed up to 17 ounces dried and about 32 pounds green. In contrast, the largest amount of dried roots sold by an individual at

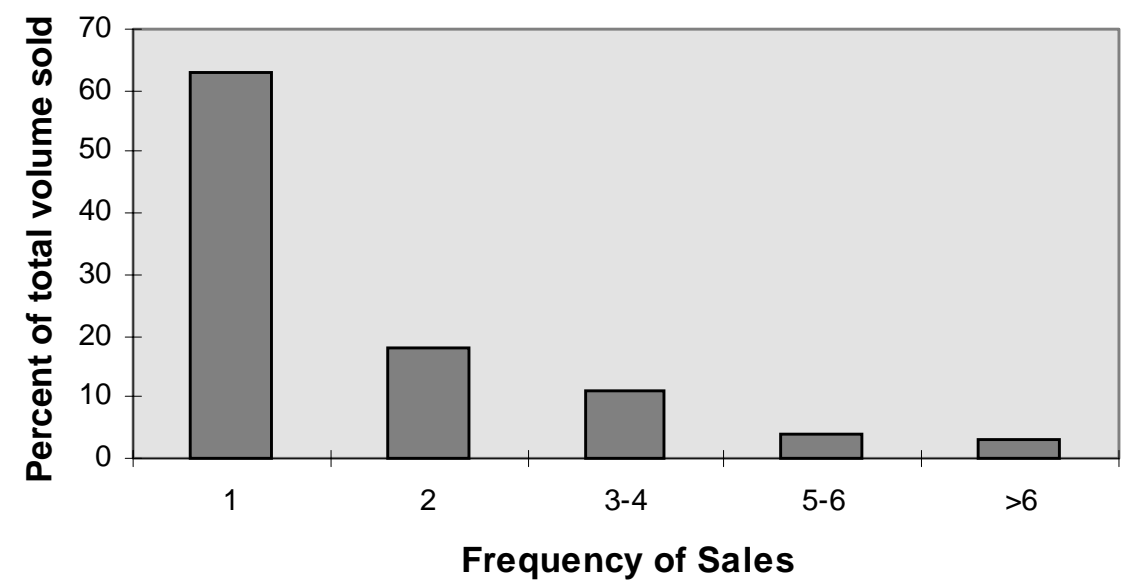

Fig. 2-3. Percent of ginseng volume by frequency of sales.

one time was 38 pounds. The magnitude of this single sale suggests that roots from several individuals could have been combined (a common practice among family groups). Alternatively, such roots could have been woods-grown. Transactions as small as $0.13 \mathrm{oz}$. (generating $\$ 2.84$ at a price of $\$ 350 / \mathrm{lb}$ ) were also recorded by dealers.

\section{Income and Price}

Though the sale of ginseng is not a mainstay in the livelihoods of most diggers, it does often represent a tax-free, seasonal supplement to limited incomes. "Most of my suppliers are on a 
'fixed income," explained a dealer, alluding to the diggers from whom he buys who depend on public assistance. Interview questions regarding regulation, taxation, and legislation generally provoked the quickest and most vehement opinions from respondents. Ginseng revenue is only taxed if diggers voluntarily report their income from the activity. The harvest's tax-free status is defended by diggers: "Government's got no right to tax me for the roots I dig," emphatically stated a digger. "I work hard to get my roots with my bare hands; the government ought to just stay out of it," said another. "I dig on [timber and coal] company land, but they let us do it because they get a tax break if we're allowed there," said a digger. "I wouldn't mind it [a tax or a license fee] if the government would plant ginseng seeds back in the woods," suggested a digger, "but I doubt they would."

Income from the ginseng harvest is used in a variety of ways. Diggers may have determined a target income goal, and cease digging once that goal is met. "Well, if I can get $\$ 75$ or $\$ 100$ in a season, I'm fine with that," reported a digger. Other diggers dedicate their revenues from sales of ginseng roots to particular activities: hunting requires cash for ammunition, fuel for transportation, and other equipment; sales in December are often linked to a need for cash for Christmas presents. "I usually use my ginseng money to buy stuff to go fishin' and huntin'," explained a digger. Data from 1994 indicate that transactions during the ginseng season peak by mid-October (Fig. 4). This probably reflects early frosts in some areas two weeks prior (ginseng roots take about 2 weeks to dry), as well as a switch in the seasonal harvest pattern to squirrel hunting. Other diggers report that frequent small sales get them gas money or hardware supplies. At the other extreme, one digger who annually sells over 15 pounds of root proudly pointed to the land on which he was building his house and said, "That's what ginseng has done for me."

Another group of diggers has more immediate gratification in mind: "I buy lots of small quantities of roots at a pretty low price," reported one dealer, "because the diggers that sell to me are the wino clientele. If they wanted to save up their roots and travel 20 miles down the road to the next dealer, they could get better prices. But these guys want their money now, since they're gonna spend it right away on their Mad Dog [wine] or beer." Some diggers sell green roots 
instead of dried (at a much lower price) rather than wait the two weeks it normally takes for drying to be completed. "Those are the ones who want their money today," pointed out a digger who also farms.

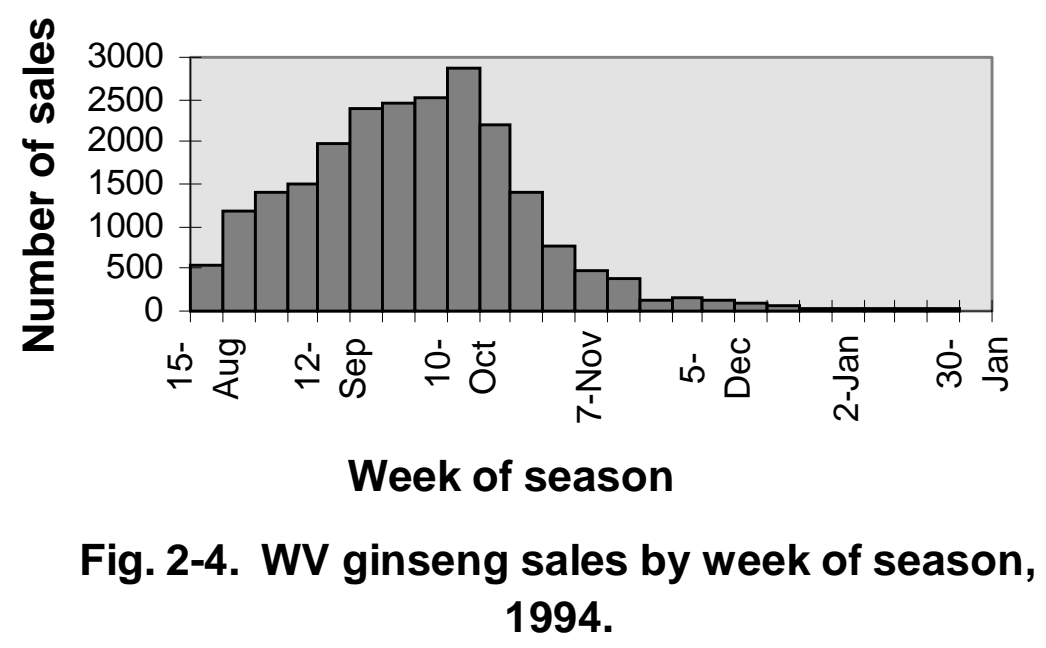

Diggers who sell more than a pound of dried wild root at a time are likely to have acquired their roots on multiple forays into the woods. They often call dealers to ask for updates on prices, and decide to sell when they think they can make the most money. Dealers will frequently offer a better price to those who bring in a full pound or more of high-quality roots. Among diggers who sell more than once during a season, $83 \%(\mathrm{n}=3149)$ are loyal to the same dealer, either because of personal relationships or convenience. The remaining $17 \%$ shift their points of sale during the season, generally based on price quotes received over the telephone.

While price undoubtedly influences when and to whom diggers will sell during a season, its influence on overall levels of harvest is tempered by other factors. In 1995, ginseng prices paid by some dealers rose to as much as $\$ 500$ per pound during the season, an increase in price over the previous year of almost $30 \%$. Interviewees suggested that the high prices were drawing more and new diggers into the trade, as well as providing incentive for routinized diggers to spend 
more time in search of roots. However, harvest figures did not peak that year. While price may have stimulated additional harvest activity, it may have been spurred by limited availability. Dealers who purchase dried roots often will open the season offering a low price, but begin to increase the amount they pay as the season progresses if they have not acquired the quantities they desire. The net effect -- of higher price leading to increased harvest effort which is limited by low availability -- can be a harvest of average size. The variability in price within a season and from dealer to dealer can vary by as much as 30\%-40\%. Dealers are reluctant to part with records of sales, and only one ginseng digger interviewed during the course of this study kept receipts of sales. Recent ginseng prices are listed in Table 2-1.

Table 2-1. Price per pound for dried ginseng root, West Virginia.

Amount listed is at first point of sale, from digger to local dealer.

Prices vary; sources reporting values within $10 \%$ of each other are referenced.

\begin{tabular}{|c|c|c|c|c|c|}
\hline Year & $\begin{array}{c}\text { Price per } \\
\text { Pound }\end{array}$ & Year & $\begin{array}{c}\text { Price per } \\
\text { Pound }\end{array}$ & Year & $\begin{array}{c}\text { Price per } \\
\text { Pound }\end{array}$ \\
\hline 1998 & $\$ 175^{1}$ & 1991 & $250^{1,2,3}$ & 1984 & $165^{2}$ \\
\hline 1997 & $280^{1,3}$ & 1990 & $220^{1}$ & 1983 & $220^{1}$ \\
\hline 1996 & $320^{1}$ & 1989 & $190^{1}$ & 1982 & $120^{1}$ \\
\hline 1995 & $415^{1}$ & 1988 & $225^{2}$ & 1981 & NA \\
\hline 1994 & $270^{1,3}$ & 1987 & NA & 1973 & $66^{1}$ \\
\hline 1993 & $240^{1,3}$ & 1986 & $132^{1}$ & 1972 & $58^{1}$ \\
\hline 1992 & $265^{1,3}$ & 1985 & $135^{1}$ & 1968 & $35^{1}$ \\
\hline
\end{tabular}

${ }^{1}$ Ginseng digger records.

${ }^{2}$ Newspaper accounts

${ }^{3}$ WV Division of Forestry

Because wild American ginseng is primarily an internationally traded commodity ultimately destined for one geographic area (Asia), market demand and price are subject to vagaries of international finance and commerce. Multiple dealers in early 1998 predicted that their ginseng purchases later in the year would be curtailed, as a result of the instability of Asian economies and unfavorable exchange rates. With slack demand, prices offered for roots were low. "My Oriental buyers don't have the cash," lamented one dealer. "I've still got 300 pounds of roots 
from last year I'd love to sell you," offered another. Thus prices, particularly low ones, can influence the volume of ginseng purchased by dealers in a given year, especially if they believe prospects for resale are not good. Nevertheless, respondents indicated that not all digging activity results in root sales during a season. While low demand may dampen harvest intensity or sales, many diggers will continue to search for and dig the root. Some will take whatever price they can get for their roots. Others will hold over the roots through the winter, hoping prices will bounce back.

\section{Lifestyle}

Ginseng diggers are strongly influenced by non-economic motivations, at times more so than by the cash incentives of harvest. Diggers who harvest annually participate regardless of price; while they are pleased to receive some cash resulting from their time in the woods, it is the time spent in the woods that they most value. "I love it; I love the woods," said a retiree who happily spends his days in pursuit of multiple species of medicinal plants. "I could make it without it but I enjoy it." One digger described the activity as "a treasure hunt; getting out for the treasure hunt is therapy." "Only 5-10\% of the diggers are in it for the money," claimed a seasoned dealer. "It's like gold," mused a large-volume digger, "once you get hooked on it, you're lost. I'll admit it, I'm addicted. You're your own boss, and there's no prettier work place."

Table 2-2. Harvest of wild products by West Virginia households, 1994-1995.

\begin{tabular}{lccc}
\hline \hline Harvest Activity & $\begin{array}{l}\text { \# participating } \\
\text { households } \\
(\mathbf{n}=\mathbf{9 2 2})\end{array}$ & $\begin{array}{l}\text { \% households } \\
( \pm 90 \% \text { conf. } \\
\text { limits })\end{array}$ & $\begin{array}{l}\text { Range of \# of households } \\
\text { statewide } \\
\text { Total }(\mathbf{1 9 9 5 ) :} \mathbf{7 0 9 , 3 2 1}\end{array}$ \\
Hunt wild game & 360 & $39 \pm 3$ & $258,193-295,645$ \\
Gather wild (plant) foods & 231 & $25 \pm 2$ & $161,087-194,283$ \\
Harvest medicinal plants & 34 & $4 \pm 1$ & $18,939-33,409$ \\
\hline
\end{tabular}

Ginseng harvest is one segment in an annual cycle of harvesting from the wild for many diggers. The 1995 telephone survey revealed the strong affinity residents of the state have for the natural resource base (Table 2-2) through hunting wild game, gathering wild foods, such as berries, ramps (Allium tricoccum), or mushrooms, and digging medicinal plants. Among ginseng diggers 
$(\mathrm{n}=34), 82 \%$ (28) were also hunters, and 47\% (16) dug goldenseal (Hydrastis canadensis), generally prior to the opening of the ginseng season in August. Each of these activities has a preferred time frame, and is a ritualized, seasonal activity for harvesters (Fig. 2-5). What the harvesters do during these different times of the year expresses their identities and their definitions of self. The activities define "who they are," in much the same way that other people see themselves as avid sports fans, theater buffs, gardeners, or athletes.

\begin{tabular}{|c|c|c|c|c|c|c|c|c|c|c|c|c|}
\hline Product & Jan & Feb & Mar & Apr & May & Jun & Jul & Aug & Sep & Oct & Nov & Dec \\
\hline Mosses & & & & & & & & & & & & \\
\hline Turkey & & & & & & & & & & & & \\
\hline Ramps & & & & & & & & & & & & \\
\hline Mushroon & & & & & & & & & & & & \\
\hline Goldense & & & & & & & & & & & & \\
\hline Ginseng & & & & & & & & & & & & \\
\hline Walnuts & & & & & & & & & & & & \\
\hline Squirrels & & & & & & & & & & & & \\
\hline Deer & & & & & & & & & & & & \\
\hline Trapping & & & & & & & & & & & & \\
\hline
\end{tabular}

Fig. 2-5. A forager's calendar of wild harvested products.

Diggers who participate in an annual cycle of activities see themselves less as harvesters, and more as skilled survivors in the outdoors, living from their knowledge of nature: as Lewis (1993) termed them, "living in the land." This culture of natural resource harvest is a cross-generational thread that unites families. Ginseng diggers almost invariably report that they learned to "sang" from a family member, usually a father or grandfather; and they frequently remember the age at which they began. "I first dug ginseng when I was 8 years old," reported a 43 -year-old father. "My great uncle taught me to put the berries back in the ground. My 16-year-old son, he's pretty good at finding it." Many diggers have continued the family tradition, teaching their own 
children to identify and dig the wild plants.... and to share the profits when the roots are sold. Dealers' records of ginseng purchases, submitted every 30 days to the state Division of Forestry, often reveal consecutive sales on the same date to individuals with the same surname but different first names; these clusters of sales generally indicate family groups, who arrive together to cash in their hard-won roots. Dealers also recorded multiple consecutive transactions on the same date to the same individual, who apparently sold the ginseng he dug, and then sold the root his brother or spouse dug, and then in a third transaction sold the root that another relative (perhaps a child) dug, and returns home with each digger's allotted income.

Interviews with diggers revealed their strong sense of pride, and a determined streak of independence. "There's a freedom to the whole tradition that shouldn't go down the tubes," said a dealer in defense of the anonymity and tax-free status of the harvest. The defiance of respondents in insisting that ginseng income is different from "regular jobs" links the harvest activity to an exercise in self-reliance. It invokes a sense of a "birth right" to wild game and wild resources that permits self-sufficiency, and maintains a lingering pioneer spirit encouraged by the strong tradition and history associated with the harvest. The suggestion of regulation or taxation irritated a respondent: “That ain't right. The plants stay stationary. The government has gone too far already. That's nature's plant [not the government's]." Efforts by state agency personnel to tighten regulations and dealer reporting requirements have been defeated by state legislators, who are reluctant to change this traditional, albeit hidden, harvest (R. Whipkey, WV Division of Forestry, pers. comm.).

The birth right may also be expressed as a "finders, keepers" attitude that defies property rights and boundaries. Diggers rarely forage exclusively on their own land; given ginseng's extensive range, diggers must scour larger areas than they are likely to own in order to consistently harvest the root from one year to the next. Indeed, few ginseng diggers interviewed for this study owned their own forest land. Many forage on private land, but not always with permission. "They [nearby landowners] don't dig it [on their property]," explained a digger, "but if I ask them if I can dig there, they'll decide it's worth something, and turn me down." In the state's eastern mountain region, diggers may enter federal (public) lands, where a permit for digging ginseng is 
required. In the western region, diggers can hunt for roots on corporate lands after paying a nominal (\$7) license fee for unlimited hunting and gathering rights. State forests do not permit ginseng harvest.

Regardless of land tenure, monitoring harvest activity is difficult for a landowner. Sangers may walk long distances, and cross multiple property lines in the course of their search. "We just call it 'the mountain"', shrugged a sanger when asked on whose property she hunted for ginseng. “Nobody lives up there, and my cousin's first wife's brother always used to tell us nobody'd mind if we went there. 'Course they'd never know, either."

\section{HARVEST PATTERNS OVER SPACE AND TIME \\ Geographic Distribution}

The ginseng harvest is not uniformly distributed around the state. Figure 2-6 shows the range (in pounds) of ginseng roots dug from West Virginia's 55 counties. Most notable is a cluster of 8 counties in the southwestern region of the state which produced 61\% of the 1994 harvest. More than $1,000 \mathrm{lb}$. of ginseng were dug in each of the high-volume counties; across the state, pounds harvested ranged from a low of 0.24 pounds in the eastern panhandle's Hardy county, to a high of $1,894 \mathrm{lb}$. from Boone county in the southwestern part of the state. The same cluster of counties, with few exceptions, annually shows up among the "top ten" counties for ginseng harvest in the state. This distinction is one of several socioeconomic and ecological attributes that resource managers and state officials use to characterize this region of the state. These attributes are related by a complex set of interactions:

- the counties have traditionally been heavily dependent economically on coal and timber;

- land ownership lies largely in the hands of timber and coal companies;

- soils are rich and well-drained but slopes are so steep as to be almost inaccessible for building and development.

- region has had limited employment stability, subject to "boom and bust" cycles;

- per capita incomes are among the lowest in the state; 
- human populations are in decline;

- deer densities per square mile are among the lowest in the state;

- annually, the counties form the dominant region for arson-caused forest fires in the state.

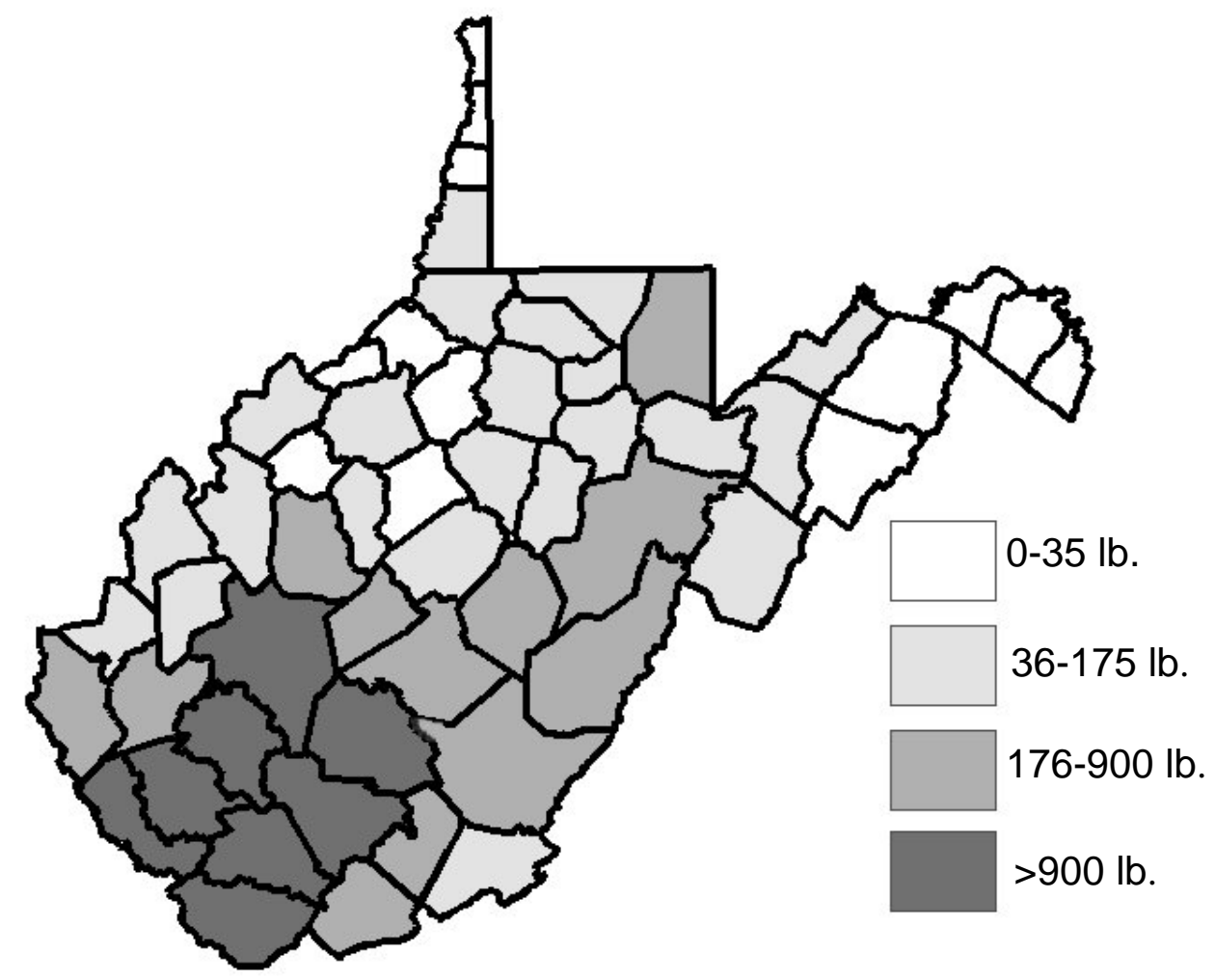

Fig. 2-6. Range of pounds of ginseng harvested from WV counties, 1994.

Multiple variables undoubtedly converge in the region to produce the high volume of ginseng harvest. Unstable employment and poverty may stimulate a large harvester effort, and lower altitudes than in the eastern mountainous region of the state may permit a longer harvest season; little active development of company lands provides large areas of suitable and available habitat; soils and forest cover are favorable for ginseng abundance; low deer populations have little limiting effect on ginseng growth and apparency. The coincidence with forest fires is less clear, but probably indicates similar effects, not causes, of some of the factors influencing the ginseng harvest (unemployment and social instability). "The diggers in the southwest part of the state are 
the most disenfranchised," a dealer stated in a matter-of-fact tone. "They can't own land and they don't have many opportunities."

\section{"Long-term" Trends}

Over time, variation in ginseng harvest in West Virginia is most closely tied to alternative employment opportunities. Figure 2-7 charts annual ginseng harvest in the state over a 17-year period (1980-1996), and the state's annual unemployment rate for the same time. As the unemployment rate rises and falls, so does the ginseng harvest, with a few exceptions. This close correlation ( $\mathrm{r}=0.79)$ implies that the more "free" (unemployed) time a digger has, the more of it s/he will spend searching for ginseng roots. Another key variable emerged during a review of newspaper accounts from the same period: 1987 and 1988 witnessed severe droughts that eventually caused all counties in the state to be declared disaster areas (Charleston Gazette 1987,

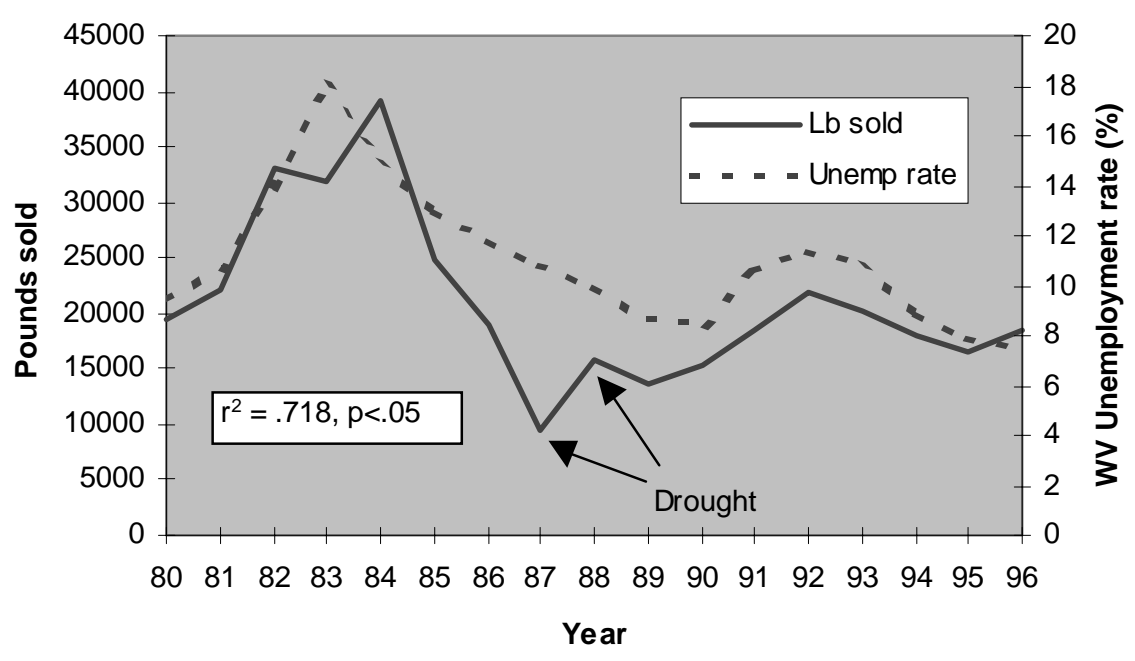

Fig. 2-7. WV ginseng harvest in relation to unemployment and drought.
1988). A multiple

linear regression analysis indicates

that together, unemployment and drought account for $72 \%$ of the variability in the ginseng harvest $\left(\right.$ adjusted $r^{2}=0.718$, t-value significance for both independent variables <0.05). ${ }^{1}$

${ }^{1}$ This is a conservative estimate. A Durbin-Watson statistic of 2.506 for the 17 -year data set falls into the "inconclusive" range (of 2.46 to 3.05) for autocorrelation, which might be expected with such a time series. Correcting for the slight negative autocorrelation with a Cochrane-Orcutt estimate actually increases the adjusted $\mathrm{R}^{2}$ to 0.822 , and reduces the $\mathrm{t}$-value significance or both independent variables to $<0.01$. 
The record harvest of 1984 harvest could have contributed to the precipitous decline in harvest in the following years, indicating low population levels of the plant, and a slow recovery. The 7year "rotation" cycle required for most ginseng plants to mature precludes analysis of periodicity in this 17-year data set.

Beyond these general, state-wide influences, more localized effects of weather, economies, fire, deer populations, and other variables -- especially in the counties which are the source of the

largest harvests -- undoubtedly affected ginseng availability and harvest intensity. Unfortunately, these dispersed influences are more difficult to identify, as well as to document: county-level economic indicators from the pre-computerized era are difficult to access, and often consist of summary reports with aggregated data. Variations in scale and coverage may mean that weather data apply to physiographic regions of the state (mountains, or river valleys) while economic data capture county-level effects. Aligning many of these data sources to create a more detailed picture of the ginseng harvest is challenging, and a precise accounting for the harvest may not be possible: Though diggers ostensibly report the counties from which their ginseng roots were dug, the accuracy of the records is uncertain. Diggers range widely, without maps, and can easily cross county lines without being aware of it.

\section{IMPLICATIONS}

Social and economic variables are likely to play a key role in determining the levels of harvest of economically valuable plant species. To understand harvest dynamics, and to manage or conserve species such as American ginseng, these data must be analyzed in conjunction with biological and ecological information, and used together as the basis for sustainable management. Unfortunately, one or the other -- the biological or the social science -- is often left out of management assessments, which can easily lead to an incomplete or inaccurate picture of the harvest and the conservation status of wild products. Wild harvested products such as ginseng and goldenseal, being neither threatened nor endangered, receive little formal protection or research funding. Nor are they at the heart of large-scale industries, and failing to generate significant, visible revenues, are overlooked as priorities in forest management. 
The link between the ginseng harvest and the dynamics of unemployment points to the critical role ginseng plays in West Virginia's communities: Ginseng is a seasonal, "fall-back" commodity, representing one of several household contingency strategies for weathering economic downturns. The harvest of ginseng is also emblematic of a rural, resource-based tradition of collecting that has continued through multiple generations of families in the Central Appalachians. Understanding harvesters' motivations, lifestyles, and needs is critical to creating management programs that are effective.

Whether wild ginseng is actually in decline is difficult to discern. The variables that determine amounts of ginseng sold are complex, and the resulting extremes in harvests prevent a clear understanding of the abundance or variability of wild populations of the plant. Given the strong correlation between unemployment and harvest figures, it seems unlikely that harvest data provide an adequate "proxy" for abundance of the plant in the wild or population trends. Unfortunately, states do not have standardized field-based data on the abundance of wild populations. State-level inventory efforts to document the status of ginseng populations will be necessary to determine the long-term viability of the species throughout its range.

The magnitude of the harvest in terms of numbers of plants removed from the forest gives pause to those who know how difficult it can be to find. Diggers, botanists, and naturalists are in general agreement that ginseng is not common, even in areas of optimal habitat. Using a state estimate of an average 300 roots per pound of dried ginseng (Whipkey in litt 1997) (used to track changes in average sizes of plants harvested, and believed to be a potential indicator of change in the age of plants harvested [Anderson 1996]), West Virginia's average harvest of almost 20,000 pounds would indicate that $6,000,000$ plants per year are taken from the forest. Some interpret this number to mean that ginseng is much more common than it is generally believed to be; others wonder how a slow-growing perennial can sustain such a level of harvest on a long-term basis.

A model of extraction proposed by Homma (1992) for Amazonia suggests that as wild sources of products become more scarce, efforts to cultivate the products increase, and eventually dominate 
the marketplace. The current mix of wild harvesting, woods grown strategies, and cultivation practices for ginseng fit neatly into the model, and lies in that phase in which wild populations are in decline. Homma postulates that wild harvest eventually ceases in favor of cultivation. However, wild ginseng root carries a premium with dedicated markets seeking the distinctive root shape that is difficult to replicate by other means of production. In addition, many rural harvesters lack land on which to grow the plant. Furthermore, the social traditions associated with ginseng and a suite of other wild harvested products in Central Appalachia are strong, and not entirely market-dependent. The combination of social factors with specialized market demand would seem to favor some motivation for continued "wildcrafting", even though other production methods may come to dominate the marketplace. In the current national ginseng management program, harvest volume is used as an indicator for status of wild populations. Unfortunately, non-wild roots are likely to begin to trickle through dealers' markets, inflating harvest volumes, and could be incorrectly interpreted as an increase in the abundance of wild ginseng.

The 8-county cluster in southern West Virginia which produces over $60 \%$ of the annual ginseng harvest demonstrates the importance of knowing the geographic provenance of the ginseng harvest in any given state. It highlights the region where regulations and management are likely to have the greatest impacts. It implies a stronger presence and role of ginseng (as well as other wild harvested products) in the community fabric; indeed, given the local population's strong sense of place (Lewis 1993), the economic cushion ginseng provides could conceivably permit families to resist otherwise economic pressures to migrate from the region. And it suggests the need for more focused, regionalized information about the ripening dates of ginseng berries, the sustainability of the resource, and the patterns of harvest. Finally, the proximity of state borders with Kentucky and Virginia points to a possible need for tri-state efforts to make seasons, regulations, and enforcement more uniform, in an attempt to sustain wild populations. 


\section{LITERATURE CITED}

Anderson, Roger C., James S. Fralish, Joseph E. Armstrong, and Pamela K. Benjamin. 1993. The ecology and biology of Panax quinquefolium L. (Araliaceae) in Illinois. American Midland Naturalist 129:357-372.

Anderson, Roger C. 1996. Monitoring harvested wild ginseng populations. Unpublished report. Submitted to Office of Scientific Authority, U.S. Fish and Wildlife Service, Arlington, Virginia.

Babbie, Earl. 1995. The practice of social research. Seventh edition. Wadsworth Publishing Company, Belmont, California.

Britton, Nathaniel Lord and Hon. Addison Brown. 1970. An illustrated flora of the northern United States and Canada. Vol. II. Dover Publications, New York.

Carlson, Alvar W. 1986. Ginseng: America's botanical drug connection to the Orient. Economic Botany, 40(2):233-249.

Charleston (WV) Gazette. 1987, Sept. 17. 45 counties eligible for disaster aid. p. 7D.

Charleston (WV) Gazette. 1988, August 6. Drought disaster area declared in WV. p. 2A.

Charron, Danielle and D. Gagnon. 1991. The demography of northern populations of Panax quinquefolium (American Ginseng). Journal of Ecology 79:431-445.

Federal Register. 1978. Export of bobcat, lynx, river otter and American ginseng: Guidelines and information needs for 1978-1979 export findings. Vol 43(69):15098-15100. U.S. Government, Washington, D.C.

Fernald, M.L. 1950. Gray's manual of botany. Eighth edition. American Book Company, New York.

Fountain, Michael S. 1986. Vegetation associated with natural populations of ginseng (Panax quinquefolium) in Arkansas. Castanea 51(1):42-48.

Gleason, Henry A. 1963. Manual of vascular plants of northeastern United States and adjacent Canada. New York, Van Nostrand.

Goldstein, B. 1975. Ginseng: Its history, dispersion, and folk traditions. Amer. J. Chinese Med. 3:223-234.

Hensley, David L., S. Alexander and C.R. Roberts (ed.) 1979. Proceedings of the First National Ginseng Conference. Lexington, KY. 
Homma, A.K.O. 1992. The dynamics of extraction in Amazonia: a historical perspective. Pages 23-31 in D.C. Nepstad and S. Schwartzman, eds., Non-timber products from tropical forests: evaluation of a conservation and development strategy. Advances in Economic Botany 9. The New York Botanical Garden, Bronx, NY.

Hufford, Mary. 1997. American ginseng and the idea of the commons. Folklife Center News 19 (1-2):3-18. American Folklife Center, Library of Congress.

Keith, Bruce, Laura Carter, and Karen Farmer. 1996. 1995 WVSIS methodology report: sample design, questionnaire, and technical forms. West Virginia University Survey Research Center, Morgantown, WV.

Lewis, Ronald L. 1993. Appalachian restructuring in historical perspective: coal, culture, and social change in West Virginia. Urban Studies 30(2):299-308.

Lewis, W.H. and V.E. Zenger. 1982. Population dynamics of the American ginseng, Panax quinquefolius (Araliaceae). Am. J. Bot., 69:1483-1490

Lewis, W.H. 1984. Population structure and environmental corollaries of Panax quinquefolium (Araliaceae) in Delaware County, New York. Rhodora, 86:1483-1490.

Millspaugh, Charles F. 1892. Flora of West Virginia (WV Ag Expt Station Bull 24).

Moerman, Daniel E. 1986. Medicinal plants of Native America. Volume 1. The Regents of the University of Michigan. Ann Arbor.

Nantel, Patrick, Daniel Gagnon, and Andrée Nault. 1996. Population viability analysis of American ginseng and wild leek harvested in stochastic environments. Conservation Biology 10(2):608-621

Patton, Michael Quinn. 1990. Qualitative evaluation and research methods. Sage Publications, Inc., Newbury Park, California.

Price, E.T. 1960. Root digging in the Appalachians: The geography of botanical drugs. Geogr. Rev. 50:1-20.

Robbins, Christopher S. 1998. American ginseng: the root of North America's medicinal herb trade. Washington, D.C. TRAFFIC North America.

Schorger, A.W. 1969. Ginseng: A pioneer resource. Trans. Wisconsin Acad. Sci. 57:65-74.

Strausbaugh, P.D. and Earl L. Core. 1979. Flora of West Virginia. Second Edition. Seneca Books, Morgantown, WV. 
U.S. Fish and Wildlife Service. 1997. Pounds (dry weight) of wild ginseng harvested in the United States from 1978 to 1996. Harvest data by state. Office of Scientific Authority, Ginseng Management Program.

WVU. Undated. Woods grown ginseng. West Virginia University Cooperative Extension Service. $14 \mathrm{pp}$. Morgantown. 


\title{
Appendix 2-A.
}

\section{SEMI-STRUCTURED INTERVIEW and QUESTIONS FOR HARVESTERS}

\author{
A. Introductory "ice-breaking”" chat regarding natural resources, hunting, timber, length of
} time lived in current residence, family structure.

B. Statement of purpose for my study, assurance of confidentiality.

C. Standard questions:

1. How long have you harvested ginseng?

2. How did you learn to harvest?

3. Have you taught others to harvest?

4. What is the largest amount you've harvested?

5. Why do you harvest (social, cultural, economic motivations)?

6. Do you personally use ginseng or other medicinal products?

7. On whose property (and where, at least at county level) do you harvest?

8. How do you go about the harvest (scouting, multiple forays, intensity, variables affecting effort, changes in harvest sites, companions)?

9. What affects the success of your harvest?

10. What other products, if any, do you harvest, and at what time of year?

11. How much money do you generally earn from harvest; how much last year; how important is that amount in your overall livelihood?

12. What do you do with the income you earn from ginseng harvest?

13. To whom do you sell the harvested products?

14. How do you decide when and to whom to sell?

15. Do you think ginseng is becoming scarce? Why or why not?

16. What do you like and dislike about the ginseng "business"?

17. What contact do you have with government natural resource managers?

18. How do you hear about changes in regulations?

19. Do you think any changes are needed for managing or regulating ginseng? 
20. Are there any differences in the range of products harvested by you, your predecessors, or your offspring?

\section{Wrap-up conversation:}

1. Confirm name, address, phone number, and request permission to call back for follow-up questions.

2. Ask about family structure: number and ages of household members.

3. Ask about sources of income for family.

4. Ask about schools, churches, community, and respondent's involvement.

5. Thanks for cooperation.

E. Post-interview:

1. Recording (taped or written) immediately after interview, with other details added within 24 hours.

2. Thank-you letter on University stationery. 
Appendix 2-B.

TOPICS REGARDING WILD HARVEST ACTIVITIES INCLUDED ON THE 1995 WVU SOCIAL INDICATOR SURVEY OF WV HOUSEHOLDS.

HARV47. (Household members hunted in past year?)

HARV48A-J6. (Animals hunted, number killed, which household participants)

$\begin{array}{ll}\text { Deer } & \text { Bear } \\ \text { Turkey } & \text { Pheasant } \\ \text { Squirrel } & \text { Raccoon } \\ \text { Rabbit } & \text { Other } \\ \text { Grouse } & \end{array}$

HARV49. (Household members gathered wild foods in past year?)

HARV50A-H6. (Foods harvested, amounts, which household participants)

Ramps

Mushrooms

Blackberries

Blueberries

Walnuts

Raspberries

Others

HARV51. (Household members gathered materials to sell for floral trade in past year?)

HARV52A-F6. (Plants harvested, amounts, which household participants)

Grape vines

Camphor vines

Mosses

Ladyslipper orchids

Other 
HARV53. (Dug or gathered wild roots or herbs to sell in past year?)

HARV54A-N6 (Kinds or roots or herbs gathered, amounts, which household participants)

$\begin{array}{ll}\text { Ginseng } & \text { Wild Yam } \\ \text { Goldenseal/Yellowroot } & \text { Bloodroot } \\ \text { Black Cohosh } & \text { Hydrangea } \\ \text { Blue Cohosh } & \text { Virginia Snake Root } \\ \text { Mayapple } & \text { Ninebark } \\ \text { Slippery Elm Bark } & \text { Other } \\ \text { Wild Ginger } & \end{array}$




\title{
CHAPTER 3
}

\section{MEDICINAL PLANTS: FAIR GAME? WILDLIFE MANAGEMENT TOOLS FOR PLANT CONSERVATION}

\begin{abstract}
Despite their long-standing importance for rural households and communities in the eastern United States, medicinal plants and other wild harvested plant products fail to occupy a clear niche within the field of resource management. The practices associated with medicinal plants management reflect the orientation of their institutional "homes" in state agencies as diverse as agricultural regulation, endangered species, forest resources, and wildlife enforcement. The characteristics that define the production and harvest of wild plants of economic importance relate to all of these agency missions. Optimal management strategies, therefore, should integrate elements of all these models. However, disciplinary divides -- particularly an approach to "wildlife" which excludes botanical resources -- often prevent resource managers from considering what their particular disciplines may have to offer to the effective management of plants of economic importance. Wildlife management techniques used for game (faunal) species such as licensing of harvesters and regionalized management regulations could improve the effectiveness of medicinal plant species management by addressing current shortcomings in funding, field work, and constituency-building.
\end{abstract}

\section{INTRODUCTION}

The growth in herbal medicine markets worldwide has been noted since the mid-1980s, with an emphasis on "natural", wild, and/or organic products (Mater Engineering 1993). As more plant species of economic value begin to raise conservation concerns, it will be important to have systems in place at the state level that can effectively address the regulation and management of their harvest. This paper examines the current approaches to ginseng management employed in the federal-state program, suggests modifications to current practices, and identifies techniques used in other resource disciplines -- particularly wildlife management -- that would permit a more thorough understanding of harvest dynamics and their impact on the conservation status of medicinal plants.

The harvest of medicinal plants such as American ginseng (Panax quinquefolius) and goldenseal (Hydrastis canadensis) has a long history in North America, dating to pre-colonial times in what was to become the United States (Harding 1908, Moerman 1986). As with many wild products, harvest motivations have included household use as well as sale for income, though with the 
advance of modern medicine the emphasis of the harvest has shifted largely to income production (Krochmal 1968). Although legal, the harvest of medicinal plants in Central Appalachia is cloaked in a tradition of secrecy, independence, and opportunism (Hufford 1997).

Despite medicinal plants' firm historic role in the economies of rural households and communities, their place in the administrative ranks of present-day natural resource management agencies is anything but clear. Current state-level ginseng management programs reflect the wide variety of their agencies' primary concerns and emphases. A national model for harvest data collection has developed largely through the U.S. Fish and Wildlife Service (USFWS) ginseng management program (Robbins 1998), but its implementation by states is uneven. For instance, the types of agencies in which state ginseng programs are located varies considerably; some agencies have direct contact with all harvesters, while others have no understanding of who harvesters are; and state-level efforts to gather information on wild ginseng populations range from systematic assessments to no activities at all.

Economic plant species such as ginseng and goldenseal exhibit a complex set of characteristics that are essential to consider in devising management schemes. Because of the complexities that define them, however, economic plants tend to fall through the cracks between disciplines. As plants, they are often outside the purview of wildlife management; as herbaceous species, they are rarely considered in forest management. As herbaceous perennials, they are long-lived, and infrequently studied in the wild: gaps in knowledge for most species include basic information on the relative importance of sexual vs. asexual reproduction, pollination, predation, dispersal, and ecological niches. As economic plants, they are not assessed by botanists in terms of abundance of wild stocks or densities, while in many regulatory agencies the product (the mature root) is the focus of monitoring, to the exclusion of other life stages of the species. As wild harvested species, their population dynamics are heavily affected by human collectors. However, harvesters in most states cannot be identified by the managing agencies, complicating accuracy in data collection and measurements of harvest effort. 


\section{METHODS}

State programs for American ginseng serve as a reference point in the development of models for managing wild harvested plant products. Ginseng harvest totals for all states since 1978 were provided by U.S. Fish and Wildlife Service (USFWS). State ginseng managers were surveyed about their programs prior to a 1997 workshop on ginseng management held at West Virginia University with financial support from USFWS (Van der Voort and Bailey 1998) (see Appendix 3-A), and were contacted for follow-up interviews after the workshop.

With an understanding of the scope and limitations of state programs, the current status of ginseng in one state (West Virginia) was used to assess possibilities for program modification.

West Virginia ginseng harvest records from 1994 were provided by the state Division of Forestry for transcription and analysis. This information provided an understanding of the type and quality of harvest reporting done annually by ginseng dealers. Interviews with medicinal plant diggers, dealers, and resource managers were conducted in West Virginia from 1993 to 1996, and provided insight into the activities, markets, attitudes, needs, and biases of the different participants in the medicinal plant trade. A 1995 telephone survey of a random sample of WV households conducted with the Survey Research Center of WVU included a set of "wild harvest" questions, and provided demographic and contextual information about harvesters (Keith et al. 1996). The various sets of information were then synthesized, weak spots in current management practices were identified, and natural resource management models used to recommend ways to improve management of medicinal plants.

\section{WILD MEDICINALS: TRADE AND MONITORING}

Wild roots, leaves, and barks continue to be harvested in the Central Appalachian states for sale as medicinal plants (Table 3-1). The highest-value product for harvesters, American ginseng root, is destined for Oriental markets through Hong Kong (Robbins 1998), but begin with a sale from a harvester to a dealer. Sales of other wild plant species to the same dealers enter separate market chains for eventual processing in the "natural remedies" market and as homeopathic medicines, both in the United States and Europe. The list of species bought by dealers from 
harvesters changes periodically in response to demand driven by consumer markets and research needs.

Among these products, only the harvest of wild American ginseng is currently managed across its range. Because ginseng is listed as a CITES (Convention on International Trade in Endangered Species) “Appendix II" species, its international trade falls under USFWS management scrutiny (Robbins 1998). The goal of the federal program is to determine whether harvest causes "no detriment" to wild populations of the species. The burden of proof rests with states, which follow a USFWS protocol for reporting ginseng harvest figures annually. Failure to support a "no detriment" finding can result in the suspension of ginseng trade on a state-by-state basis, though in practice this has not occurred.

Goldenseal, another herbaceous perennial, was listed as a CITES Appendix II species in 1997. USFWS has pursued a reporting mechanism for monitoring goldenseal harvest which relies on cooperation from industry buyers and producers (TRAFFIC 1998). Prior to its listing, states expressed concerns that a goldenseal program operating in the same manner as ginseng would place an undue burden on state agencies (Van der Voort and Bailey 1998). Although the price per pound of goldenseal root is roughly $10 \%$ of ginseng's, its clonal growth habit results in dense patches, increasing its apparency. According to harvesters, it is possible when in the right habitat to collect larger quantities of roots in less time than when searching for ginseng. Furthermore, goldenseal harvest is not restricted to a season, as ginseng is.

No other wild medicinal plants in ginseng-harvesting states have controlled harvests or harvest monitoring. In West Virginia, less than half the number of ginseng-harvesting households also harvest goldenseal. The lower prices paid per pound of product for other species (Table 3-1) relegate their collection to few harvesters with few economic alternatives, recreational harvesters, or specialist harvesters who focus almost exclusively on one product and are likely to work in family groups. 
Table 3-1. Medicinal plants routinely traded in West Virginia, 1992-1999, and approximate prices paid in 1998-1999 to harvesters, as reported by dealers.

\begin{tabular}{|c|c|c|}
\hline Common name & Scientific name & Price $/$ lb $^{a}$ \\
\hline American ginseng (root) & Panax quinquefolius & $\$ 230.00$ \\
\hline Bethroot (root) & Trillium erectum & 0.50 \\
\hline Black Cohosh (root) & Cimicifuga racemosa & 1.25 \\
\hline Bloodroot (root) & Sanguinaria canadensis & 4.00 \\
\hline Blue Cohosh (root) & Caulophyllum thalictroides & 0.75 \\
\hline Burdock (root) & Arctium lappa & 1.00 \\
\hline Goldenseal (tops) & Hydrastis canadensis & 3.50 \\
\hline Goldenseal (root) & Hydrastis canadensis & 30.00 \\
\hline Hydrangea (root) & Hydrangea arborescens & 0.80 \\
\hline Mayapple (root) & Podophyllum peltatum & 0.25 \\
\hline Mullein (leaf) & Verbascum thapsus & 0.75 \\
\hline Poke (root) & Phytolacca americana & 0.50 \\
\hline Queen of the Meadow (root) & Eupatorium purpureum & 0.50 \\
\hline Sassafras (leaf) & Sassafras albidum & 0.75 \\
\hline Sassafras (root bark, rossed ${ }^{b}$ ) & Sassafras albidum & 3.50 \\
\hline Slippery elm (bark, rossed) & Ulmus rubra & 2.00 \\
\hline Star grub (root) & Chamaelirium luteum & 17.00 \\
\hline Virginia snake root (root) & Aristolochia serpentaria & 17.50 \\
\hline White willow (bark) & Salix alba & 0.25 \\
\hline Wild ginger (root) & Asarum canadense & 0.75 \\
\hline Wild yam (root) & Dioscorea villosa & 1.20 \\
\hline Witch hazel (leaves) & Hamamelis virginiana & 1.25 \\
\hline Witch hazel (bark) & Hamamelis virginiana & 0.85 \\
\hline
\end{tabular}

${ }^{\text {a N}}$ Not all prices are the same for all dealers; in the case of differences, values represented are averaged.

${ }^{b}$ Hard outer bark is separated from soft inner bark, and discarded. 
At present, the national ginseng management program is predicated largely on the assumption that harvest figures indicate population trends of wild ginseng: Years of large harvests are presumed to indicate abundance, and years of low harvest are taken as indicators of scarcity. This assumption, however, has not been validated. In fact, harvest totals from West Virginia appear to be mostly dependent on unemployment and weather extremes (Figure 3-1). Since estimates of

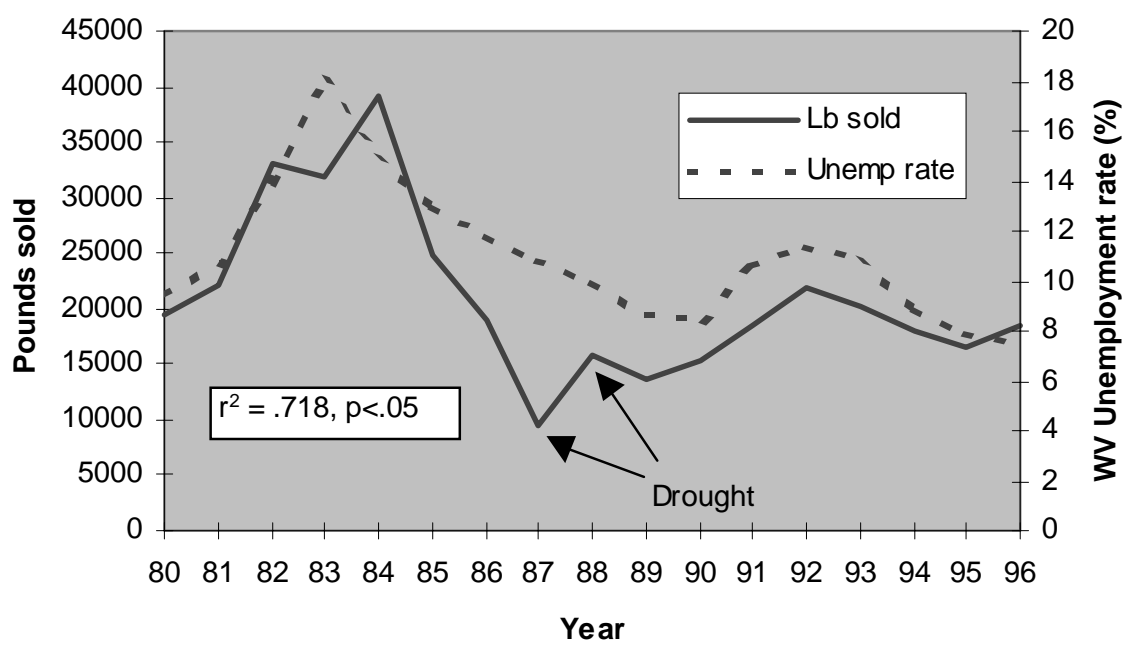

Fig. 3-1. WV ginseng sales, unemployment, and drought

statewide abundance of wild American ginseng based on field studies are not available, the percentage of wild populations harvested annually cannot be known, and increases or declines in populations can not be confirmed. Consequently, some state program managers question whether monitoring ginseng harvests is actually necessary, and whether the information they are required to produce for USFWS can answer the questions that the national program is asking.

State programs also record counts of roots per pound during the ginseng season. A trend toward increasing numbers of roots per pound would be interpreted to mean that smaller, and therefore younger, plants are being harvested. From this managers would infer that the age structure of wild populations is compressed, and that older plants are less common (Anderson 1996). Because older plants generally produce more seeds (Lewis and Zenger 1982), younger 
populations are likely to exhibit reduced rates of reproduction and population growth. However, such counts lack a standard protocol: State inspectors perform the counts on an ad-hoc or occasional basis, roots counted may not be representative of overall harvest during a season, and different soils and regions of states produce different sizes and shapes of roots. Thus comparisons between states, or between regions within a state, may not be valid.

Table 3-2. Status of ginseng management programs, 1997.

\begin{tabular}{|c|c|c|c|c|c|c|c|c|c|}
\hline State & $\begin{array}{l}\text { Mng. } \\
\text { model }^{\mathrm{a}}\end{array}$ & dig & $\begin{array}{l}\text { Licen } \\
\text { deal }\end{array}$ & $\begin{array}{l}n g^{b} \\
\text { other }\end{array}$ & dig & $\begin{array}{c}\text { Fee }(\$ \\
\text { deal }\end{array}$ & grow & $\#$ diggers ${ }^{c}$ & $\#$ dealers ${ }^{c}$ \\
\hline$A L$ & 1 & $y$ & $y$ & $g$ & 10 & 100 & 50 & 485 & 10 \\
\hline AR & 1 & $\mathrm{n}$ & $y$ & - & - & 50 & - & $500-600$ & 4 \\
\hline GA & 2 & $\mathrm{n}$ & $y$ & $\mathrm{~g}$ & 0 & 0 & 0 & $250-300$ & $15-20$ \\
\hline IL & 3 & $y$ & $y$ & g & 7.50 & $50^{d}$ & 25 & 3467 & 49 \\
\hline IN & 2 & $\mathrm{n}$ & $y$ & - & - & 25 & - & unk & 70 \\
\hline 10 & 4 & $y$ & $y$ & $g$ & 10 & 100 & - & 1000 & 20 \\
\hline KY & 1 & $\mathrm{n}$ & $y$ & - & - & 0 & - & unk & 120 \\
\hline MD & 1 & $y$ & $y$ & - & 2 & 20 & - & 420 & 8 \\
\hline MN & 2 & $\mathrm{n}$ & $y$ & - & - & 5 & - & 1000 & 50 \\
\hline MO & 2 & $\mathrm{n}$ & $y$ & - & - & 0 & - & $100+$ & 28 \\
\hline NC & 1 & $\mathrm{n}$ & $y$ & - & 0 & 0 & - & unk & 62 \\
\hline NY & 2 & $\mathrm{n}$ & $y$ & - & - & 0 & - & $400-500$ & 92 \\
\hline $\mathrm{OH}$ & 4 & $\mathrm{n}$ & $y$ & - & - & 50 & - & $1000-1500$ & $75-80$ \\
\hline $\mathrm{PA}$ & 3 & $\mathrm{n}$ & $y$ & - & - & 50 & - & $\mathrm{nr}$ & $\mathrm{nr}$ \\
\hline $\mathrm{TN}$ & 2 & $\mathrm{n}$ & $y$ & - & - & 250 & - & 1000 & 65 \\
\hline VA & 1 & $n$ & $y$ & - & - & 10 & - & $5000-6000$ & 65 \\
\hline VT & 1 & $y$ & $y$ & - & 0 & 0 & - & 100 & 4 \\
\hline WI & 2 & $y$ & $y$ & $g$ & $15^{\mathrm{d}}$ & 25 & 0 & 2000 & 24 \\
\hline WV & 3 & $\mathrm{n}$ & $y$ & - & - & 10 & - & 12000 & 92 \\
\hline
\end{tabular}

a 1 = Agriculture/regulation; 2 = Natural Heritage/Endangered Species; 3 = Forestry; 4 = Wildlife ${ }^{b}$ dig=diggers, deal=dealers, $n=n o, y=y e s, g=$ growers; ${ }^{c} n r=$ no response, unk=unknown; ${ }^{d}=$ out-of-state fees double 


\section{STATE MANAGEMENT MODELS}

Since 1978, the USFWS has issued permits to states for the export of American ginseng, as long as they comply with requirements of the national program. No funding for administration of programs accompanies the management requirement. Each state receiving an export permit designates an agency to house its ginseng program. State program managers coordinate data collection and submission to the federal level. State managers receive harvest data from licensed dealers, who report the number of pounds of roots purchased from diggers. No program managers are dedicated exclusively to ginseng work; all have other responsibilties as well. Characteristics of state programs are presented in Table 3.2.

The placement of ginseng programs within state governments indicates the wide variety of institutional "homes" that house wild plants with economic value. Regardless of institutional placement, most state ginseng programs submit similar data and generate similar information. Nevertheless, the primary orientation of each agency lends particular strengths and weaknesses to each program. Though state agencies vary considerably in their structures, four basic emphases define current ginseng management programs:

Agricultural commodity regulation: Seven of 19 wild ginseng programs are based in agencies or departments which regulate agricultural production, nurseries, exports of crops out of state, and control of weeds and pests. Record-keeping, certification of dealer purchases, and compliance with federal guidelines are of primary concern. Limitations include field staff that have more of a production and agricultural orientation than a conservation or forest management perspective, and the low priority ginseng is accorded (largely due to funding, but also as an "outlier" activity) among the multiple areas that are to be regulated.

Natural heritage and endangered species management: Six ginseng programs are administered by bureaus that have species rarity as a prime concern: vulnerable, threatened, or endangered species, or species on a "watch" list. In some cases, programs for plants of conservation concern are addressed in different administrative units than 
animals of conservation concern. A potential ultimate outcome in this management structure is protection, through restricted harvester access, for those species that are determined to be vulnerable or threatened. A limitation in states with endangered species legislation is the sheer number of species that are on lists that should be monitored, but for which funding is inadequate.

Forest resources: Three states administer ginseng as a forest product, and rely on licensed industry operators (dealers) as key partners in tracking the volumes harvested. Little field work in monitoring wild populations is conducted; field staff often have limited experience with herbaceous perennials and monitoring methodologies. Forest management practices that emphasize timber production are unlikely to incorporate herbaceous species into management plans.

Wildlife: Two states depend on agencies with law enforcement authority to protect resources, regulate harvest, and/or administer licensing mechanisms already in place for other resources such as wildlife. Wildlife (game) management programs are usually funded by hunting license sales, excluding wild plant products from their activities.

Potential tools are available for improving medicinal plant management programs which derive from various resource disciplines (Table 3-3). To avoid limitations inherent in their home agencies, some state programs have cooperative agreements with universities or other state bureaus to carry out particular functions of their programs, such as law enforcement or monitoring of study plots. 
Table 3-3. Management models and activities with potential application for wild medicinal plants. Starred items (*) are those that are already employed in most state ginseng programs.

\begin{tabular}{|c|c|c|c|}
\hline AGRICULTURE & $\begin{array}{l}\text { NATURAL HERITAGE / } \\
\text { ENDANGERED SPECIES }\end{array}$ & FORESTRY & WILDLIFE \& FISHERIES \\
\hline Certification of production * & Protection of rare species* & Close contact with industry (dealers) * & Law enforcement* \\
\hline Issuance of permits/licenses * & Restrict access to key areas & Size-limited harvest ${ }^{\star}$ & Age-limited harvest* \\
\hline Summaries of production* & Forbid use or harvest & Site preparation & Seasonal restrictions* \\
\hline \multirow[t]{7}{*}{ Regulations management ${ }^{*}$} & Monitoring & Regeneration cuttings/thinnings & Licensing of harvesters \\
\hline & Reintroductions & Concessions (on public lands) & Assessment of stocking levels \\
\hline & & Assessment of stocking levels & Hunter education \\
\hline & & Seeding & Stocking \\
\hline & & Monitoring & Habitat management \\
\hline & & & Regionalized management/regs \\
\hline & & & Monitoring \\
\hline
\end{tabular}


While USFWS officials are sensitive to the difficulties inherent in imposing management requirements on states, the administrative (financial) burden assumed by states is nonetheless a source of tension. Ginseng management is viewed by states as a costly but necessary imposition of regulations which allows the state's harvest to continue. Program funding sources in states are principally agency line items or general revenue funds from the state government; the investment in programs is sufficient to comply with federal reporting requirements (certification of harvests, tallies of dealer reports, classification of root sales as wild, cultivated, or woods grown), but little else (research or monitoring).

Six of 19 programs report that they license diggers; 4 of them sell licenses to diggers, generating "user fees" ranging from $\$ 840$ in Maryland to $\$ 30,000$ in Wisconsin. Numbers of diggers (based on number of license sales in 6 states, and estimates in 11 others) range from 100 in Vermont to 12,000 in West Virginia, though totals are believed to vary from year to year. Three states report the number of diggers as "unknown." Diggers may purchase licenses through a variety of means, depending on the state: by mail, in person at regional or district offices in person, through dealers, or through sporting goods stores. Iowa is planning to launch electronic registration through its licensing bureau.

All state programs license dealers of wild ginseng. Licenses are free in 7 states; at the other extreme, Tennessee charges \$250 to its 65 dealers. The number of dealers in each state in 1997 ranged from 4 in Arkansas and Vermont to 120 in Kentucky. Dealers are pivotal in reporting sales totals to state agencies states. They are the primary conduit for communicating any changes in state regulations to diggers, though their effectiveness is difficult to evaluate. They are also a valuable information source about changing market demands, price data, and trends.

In the absence of a standard protocol for assessing wild ginseng abundance, and limited funding, personnel, and trained botanists, monitoring of field populations becomes a low priority that is conducted (if at all) on an occasional basis. Nine states conduct no monitoring or inventory in the field. New population locations are periodically added to Heritage databases, if ginseng is listed as a priority species, but its non-endangered status classifies it as a lower priority. 


\section{WILDLIFE MANAGEMENT TECHNIQUES: A RESOURCE?}

Ironically, though wildlife (game) management agencies are among the least used for managing ginseng, their practices have contributed substantially to designs for existing programs. Ginseng and other herbaceous perennials exhibit characteristics that are similar to those of many wildlife species. Chief among them is seasonality: As with many hunting regulations, harvest seasons for ginseng (which open between August 15 and September 1) are designed to begin after reproduction has occurred and berries containing seeds have ripened. As with large game species, the harvest of immature individuals is discouraged: All states' harvest guidelines stipulate that ginseng plants should be at least " 3 -prongers" (the number of leaves), indicating the plants have reached reproductive maturity, before they are harvestable.

Other wildlife techniques may lend themselves to the management of harvest programs for wild plants as well. Though the magnitude of harvest, and therefore of management effort, varies considerably among states, programs could address current shortcomings by considering the following:

1. Licensing the harvesters. Licensing of wild plant harvesters can provide many of the same benefits that wild game licensing provides. In the case of medicinals, licensing can be a mechanism to:

- identify an agency's and a resource's constituency. The inability of ginseng programs to identify and enumerate harvesters limits their political clout and ability to innovate in management of the resource. States without licensing mechanisms have no lists of harvesters or their mailing addresses. A direct connection between the managing agency and the harvester is a basic tenet of most wildlife management systems.

- educate and communicate with users. Communications conducted solely through intermediaries such as dealers or newspaper releases are passive contacts, dependent for success on circumstances and coincidence that are largely out of control of the agencies, and which may be misinterpreted or missed entirely by the audience. Agencies which conduct mailings to licensees and which send out annual renewal forms for licenses 
reinforce their role, authority, and opportunities to interact with harvesters to promote "best management" practices and changes in regulations.

- conduct periodic surveys of users. Harvester motivations, patterns, and trends can be monitored through mail-back surveys or telephone surveys. They can also facilitate agency self-evaluation, identify problem areas, and improve management procedures. States without licensing mechanisms are unable to effect such feedback.

- enlist support in stewardship of the resource. Programs that communicate to users the rationale for legal harvests, accurate reporting, and status of the resource provide an opportunity for users to take responsibility for their actions and the health of the resource.

- generate funding for research, monitoring, and management. Users who are required to purchase a license will expect that the resource will be actively managed. While compliance with record keeping and certification may be mandates, additional funds generated from user groups and dealers should be used for management and research activities for the resource, in much the same way that license fees for wildlife are used to sustain game populations. A $\$ 10$ license fee in states with at least 1,000 diggers could generate sufficient funds for initial summer inventories.

Results from a 1995 social indicator survey in West Virginia revealed that $80 \%$ of the state's ginseng harvesters were also hunters of wild game. Therefore the concept -- at least in one state - of licensure as part of harvest activity is not a new one. Indeed, interviews with ginseng diggers in WV indicated that ginseng hunting parallels game hunting: Harvesters scout areas, pride themselves on their ability to detect their quarry in the forest, are guarded about their techniques and "hunting" grounds, and develop a lore about the quality (size, shape) of the individuals they harvest and their experiences.

Impediments to licensing are not insignificant. In an anti-taxation era, licensure can be politically unpopular if it is construed as taxation. States which require legislative approval for 
changes in natural resource regulations may find legislators resistant to altering a traditional and "hidden" activity that is part of the rural fabric (it is also tax-free, if diggers choose not to report their income). Similarly, harvesters who suspect that their sales will be reported for tax purposes may seek to avoid the legal system. License fees in some states may also feed directly into general revenue funds, and not be directly available to the managing agency. Furthermore, some state agencies in which ginseng programs are based may lack the administrative capacity or authority to sell licenses.

2. Regionalized management. Plant harvest regulations that are uniformly applied around a state, from north to south and low to high elevations, may be overlooking significant differences in ripening dates for seeds, abundance and density of the resource, harvester concentrations, and enforcement needs. State harvest data can be analyzed to identify geographic differences in harvest totals, and suggest areas of emphasis for management activities. In many states, deer hunting regulations are issued by districts, with different opening dates and bag limits, based on abundance of the resource. Such an approach could also be applied in ginseng-producing states. Regionalized management would also permit inter-state areas (such as border areas comprising southern West Virginia, western Virginia, and eastern Kentucky) to standardize harvest seasons and regulations across multi-state regions that share similar physiographic and ecological characteristics.

Difficulties of regionalized management are largely administrative, but also informationdependent. Not all state agencies operate on a regional or district basis, and regionalized management practices require adequate personnel to design and administer region-based regulations. Furthermore, they require an adequate analysis of existing harvest data, and estimates of population abundance of the resource on a regional level.

3. Field-based monitoring. In game management, harvest regulations vary according to abundance of the resource, and wildlife harvest levels in one year are often used to guide harvest regulations in the following year. However, this information is often supplemented by field based techniques such as pellet counts, radio telemetry, and capture-recapture efforts. The 
economic value of wild plants links their harvest totals more to other income-producing opportunities than to the status of wild populations. Changes in harvest totals from one year or one region to the next may indicate changes in abundance of the resource, but they may also indicate changes in harvest effort. Substitutes for field work to assess population levels have not

been validated. Because perennials are long-lived, long-term studies of population dynamics and the interactive effects of harvesters, economics, weather, deer browsing, and other variables can only be discerned over time.

Similarly, increasing numbers of roots per pound of dried ginseng may indicate that smaller plants are being harvested, but as with other types of harvest data they do not indicate areas where populations are not harvested, or areas where populations no longer exist. Counts of roots per pound are further complicated by the trend toward cultivation or its variants, such as "woods grown" plants (WVU undated), and the likelihood that non-wild roots will be mixed in with wild ones, skewing average size of roots and inferences programs may make from that information about health, age, and status of wild populations.

Techniques for assessing stocks of economic herbaceous plants are somewhat unrefined, and botanists with limited time and resources can do little more than keep tabs on a few populations to verify presence/absence, and possibly numbers of individuals. Statewide inventories or assessment tools are needed to indicate resource abundance, and a smaller number of long-term control populations should be monitored for changes in age structure and impact of harvest activities. Control plots should include some that are well-protected, and others that are on private lands. Widespread assessment tools to provide broader coverage of abundance may best be undertaken by agencies with field staff (who are likely to need training), or through cooperative agreements with universities.

\section{CONCLUSIONS}

\section{Current limitations}

Management practices for economic plants in most states currently focus on compliance with federal regulations, but do little to supplement management activities. Limited funds, already 
invested in compliance, offer little room for additional efforts beyond satisfying federal mandates. Moreover, agencies tend to place higher priority on species that are more endangered (natural heritage programs), or more lucrative for producers (traditional forestry and agriculture), or more identified with a known constituency (wildlife and forestry). Finally, the multiple characteristics that define wild harvested plants of economic value generally prevent a close fit with the ongoing functions and capacities housed in any single agency structure. Wildlife management techniques used to regulate hunting systems would be valuable additions to current practices associated with the harvest of economic plants. However, plant sciences are frequently excluded from the curricula and training of wildlife biologists (Arner et al. 1998), and these gaps commonly carry over to professional settings.

An overarching goal for management of economic plants should be the maintenance, if not increase, of populations of target species. Ironically, economic species such as ginseng or goldenseal would become eligible for recovery funds if the species were to become federally threatened or endangered. Ironically, at that point commercial activities would be eliminated. Investment in preventive measures to ensure that harvests can be sustained would be less costly for governments than recovery, while maintaining a vital, natural-resource based rural tradition. However, state agencies which currently manage ginseng harvests may have little concern about additional endangerment costs if endangered species are not part of their purview; elimination of trade would simply shift managment burdens to another agency.

Cultivation of ginseng, goldenseal, and other medicinal species creates problems and possibilities for management of the wild harvest. First, mechanisms to confirm that harvest data are truly indicative of wild roots are of limited reliability, since dealers have little incentive to query harvesters as to the source and production methods of their products, and harvesters prefer to divulge as little information as possible. Secondly, cultivation is not recent, as evidenced by publications from the early 20th century extolling the virtues of cultivation of woodland medicinal plants (Harding 1908), creating some uncertainty that current "wild" stocks have actually developed without influence of previous diggers. Diggers frequently report that upon harvest, they pocket some or all the seeds of mature ginseng plants and plant them nearer to their 
homes, or in woodlands that they can more easily monitor. Indeed, the lengthy interaction of medicinal species with humans poses the question: What is wild? Cultivated stock (including woods grown material) may also relieve harvest pressure on wild populations, but it may also interact with native wild material. Since provenance of seed sources is not regulated, genetic impacts of its introduction are difficult to identify.

\section{Potential management improvements}

Economic plants are among the few consumptive resources that are not subject to user fees, and agencies with financial needs and medium to large harvests may find it to their advantage to generate funds from diggers and dealers. Those states that have made efforts to generate income from ginseng license sales have used funds to conduct more field work, monitor harvests and harvesters more closely, or made purchases of equipment to enhance their efforts, such as scales used to certify weight of ginseng roots reported by dealers. States with relatively small ginseng harvests may be unlikely to realize sufficient returns to justify the administrative costs associated with closer contacts with diggers, but states with medium to large harvests could be in a stronger position to justify a "no detriment" finding by tightening their direct agency-harvester contacts. Not all medicinal plants require equal scrutiny, or reporting. However, licenses issued for harvesters which include multiple harvested species may be just as effective (and require little additional effort) as those issued for one or two species.

Dealers in economic plants remain key to reporting harvests, but periodic surveys of users would provide opportunities to corroborate accuracy of dealer reporting. Rather than depend on dealers to act as conduits for the managing agency, a greater emphasis should be placed on dealers to provide an "early warning system" for species with surges in market demand or price. Dealers should be surveyed annually by telephone for price data on commodities, and annual reports of products purchased, perhaps above a particular weight minimum, could be implemented.

Principles of conservation of rare and endangered plant species (Schemske et al. 1994) apply generally to economic plant species, but the greater abundance of the wild harvested species and the human harvest dynamic suggest modifications and a broader array of management options. 
Efforts should be undertaken to measure harvester intensity and its impact on ginseng population dynamics. Coarse-scale assessments of population distribution and abundance would provide a baseline on resource availability. States that consider supporting ginseng harvest by seeding areas would benefit from analyses of genetic variability of seed stocks from different parts of the species' range.

Though the "unfunded federal mandate" of ginseng management is viewed by many state agencies as a burden, there is also an acknowledgement that without such a mandate, even less would be done to monitor the harvest. State agencies that are subject to legislative approval for regulations and implementation of management practices are subject to political whims that have little to do with sound resource management. They are likely to find it difficult to initiate improvement in their programs unless additional federal mandates are imposed on them. State program managers suggested that cost sharing between federal and state agencies would be the most equitable and politically palatable approach to modifications in management. Pilot efforts for modified management in key states or regions would provide states and USFWS with a chance to test alternative systems gradually.

Management of medicinal plants poses special challenges because the parameters that define their harvest, trade, reproduction, and distribution cross disciplines and traditional resource management models. Efforts to integrate disciplines and agency strengths will be required to conserve species of economic importance and sustain the traditional harvest. 


\section{LITERATURE CITED}

Anderson, R.C. 1996. Monitoring harvested wild ginseng populations. Unpublished report., U.S. Fish and Wildlife Service, Office of Scientific Authority. Arlington, VA.

Arner, D. H., S. Johnson, and D. W. Speake. 1998. Are we neglecting the plant sciences in our wildlife curricula? Wildlife Society Bulletin 26(1):38-40.

Harding, A. R. 1908. Ginseng and other medicinal plants. 1972, Reprint. Emporium Publications, Boston, Massachusetts.

Hicks, Ray R. Jr. 1998. Ecology and management of central hardwood forests. John Wiley and Sons, Inc. New York, New York.

Hufford, M. 1997. American ginseng and the idea of the commons. Folklife Center News 19(12):3-18. American Folklife Center, Library of Congress.

Hunter, M. L. Jr. 1990. Wildlife, forests, and forestry: Principles of managing forests for biological diversity. Prentice-Hall, Inc. Englewood Cliffs, New Jersey.

Keith, Bruce, Laura Carter, and Karen Farmer. 1996. 1995 WVSIS methodology report: sample design, questionnaire, and technical forms. West Virginia University Survey Research Center, Morgantown, WV.

Krochmal, A. 1968. Medicinal plants and Appalachia. Economic Botany 22(4):332-337.

Lewis, W. H. and V. E. Zenger. 1982. Population dynamics of the American ginseng Panax quinquefolium (Araliaceae). American Journal of Botany 69(9):1483-1490.

Mater Engineering. Ltd. 1993. Special forest products market analysis for Saskatchewan Timberlands Division, Weyerhaeuser Canada, Ltd. Canadian Forest Service, Prince Albert, Saskatchewan.

Moerman, D. E. 1986. Medicinal plants of native America. Volume 1. University of Michigan Museum of Anthropology. Technical Reports, No. 19. Ann Arbor, Michigan.

Robbins, C. S. 1998. American ginseng: the root of North America's medicinal herb trade. TRAFFIC North America, Washington, D.C.

Scalet, C. G., L. D. Flake, and D. W. Willis. 1996. Introduction to wildlife and fisheries: an integrated approach. W. H. Freeman and Co., New York, New York.

Schemske, D. W., B. C. Husband, M. H. Ruckelshaus, C. Goodwillie, I. M. Parker, and J. G. Bishop. 1994. Evaluating approaches to the conservation of rare and endangered plants. Ecology 75(3):584-606. 
Smith, D. M., B. C. Larson, M. J. Kelty, P. M. S. Ashton. 1997. The practice of silviculture: applied forest ecology. John Wiley and Sons, Inc. New York, New York.

Smith, R. L. 1990. Ecology and field biology. Fourth Edition. Harper Collins Publishers. New York, New York.

TRAFFIC North America. 1998. CITES species update: goldenseal. Newsletter in international trade in wildlife and wildlife products. Volume 1(2). June. Washington, D.C.

Van der Voort, Martha, and Brent Bailey. 1998. Ginseng workshop summary. Unpublished report. Division of Forestry, West Virginia University, Morgantown.

WVU. Undated. Woods grown ginseng. West Virginia University Cooperative Extension Service. Morgantown, West Virginia. 


\section{Appendix 3-A}

\section{Ginseng Workshop Questionnaire for State Program Managers}

Please circle the appropriate answer and/or provide a short response.

1. What types of ginseng are being sold from the state:

$\begin{array}{lllll}\text { wild } & \text { wild simulated } & \text { woods grown } & \text { cultivated } & \text { other } \\ \text { 1. YES } & \text { 1. YES } & \text { 1.YES } & \text { 1. YES } & 1 . \text { YES } \\ \text { 2. NO } & 2 . \mathrm{NO} & 2 . \mathrm{NO} & 2 . \mathrm{NO} & 2 . \mathrm{NO}\end{array}$

Of that, roughly what proportion is wild?

3. DON'T KNOW

2. What type of licensing is required and of whom?
Annual - Diggers
Annual - Dealers
Other
1. YES
1. YES
2. $\mathrm{NO}$
2. NO

3. What is the cost of licensing?

4. Is there a monitoring program on wild ginseng ongoing in your state?

1. YES

2. NO

If the answer is YES, in what Department of Agency? 
5. How is your state ginseng management program funded?

$\begin{array}{llll}\text { User fees } & \text { Dealer taxes } & \text { Agency line item } & \text { Other } \\ \text { 1. YES } & \text { 1. YES } & \text { 1. YES } & \\ \text { 2. NO } & \text { 2. NO } & \text { 2. NO } & \end{array}$

6. Does the managing agency communicate directly with diggers?
1. YES
2. NO

7. Are ginseng transactions reported to the state by the managing agency for tax purposes?
1. YES
2. NO

8. What are the opening and closing dates of ginseng harvest season in the state?

Open:

Close:

9. How many diggers does the agency estimate are in the state?

10. How many dealers of ginseng does the state recognize? 
11. How much income does ginseng produce for diggers in your state every year:

12. What other economically valuable plant species are managed by the agency in a similar way?

Please feel free to write on the back of this page if you need additional room for your answers to any of the above questions (please label the question you are answering) and/or if there is anything else related to ginseng management and monitoring you would like to comment on. Thank you very much for your input.

Name and Agency: 


\title{
CHAPTER 4 \\ WHEN LANDSCAPE IS LIVELIHOOD: \\ CHANGES IN FOREST, FARM, AND FOOD
}

\begin{abstract}
Ghana's forest resources are dwindling. Those large forests that remain are primarily restricted to protected areas. However, increasing demand for forest products from a declining resource base has reduced biotic resources in the forests, as well as created shortages of products for local residents. A ban on harvest of non-timber forest products from a forested area protected for conservation purposes created difficulties for local residents by reducing incomes, increasing cash needs, and eliminating sources of protein, medicines, and household items. It also changed seasonal patterns of natural resource use for families and communities. Farmers indicated that because the forest was left standing, they continued to receive the benefit of moderated temperatures, wind, and precipitation. However, they also reported increase losses due to crop raiding by animals. Adaptations to landscape change are often necessary, but difficult, for natural resource-dependent communities. Economic development projects may offer compensatory income opportunities, but are challenged to provide substitutes for the range of social and cultural values that are lost when access to forests is eliminated.
\end{abstract}

\section{INTRODUCTION}

Human communities that depend directly on a natural resource base for their livelihoods are challenged to adapt when the resource base is degraded or reduced in size. Mineral extraction, logging, conversion of forest lands to agricultural production, dams, human migrations, and even the protection of lands for conservation purposes can change the local landscape, both literally and figuratively (Gornitz and NASA 1985, Omohundro 1985, Glass and Muth 1989, Dei 1990, Lewis 1993). Such changes can restrict or eliminate livelihood activities such as hunting of wild game, gathering of foods or medicinal plants, and collection of household materials. These products are often important in the household economies of local communities, since they may be harvested for personal consumption, trade, or income-generating sales, or some combination of these uses. However, their values are rarely quantified, nor their losses documented, when landscape conversion occurs.

This case study from Ghana, West Africa, examines the range and extent of impacts felt by rural households and local communities following a loss of access to forest resources. In this case, the 
"loss" of the forest was actually a prohibition on entering an area recently declared a national park by the national government. Many impacts of the loss were the same as if the forest had been cleared, since local products were (ostensibly) unavailable to local communities. However, other impacts, both positive and negative for villagers, were felt at the local level because the forest remained standing. Identification of these impacts highlights the importance of understanding local livelihood strategies in areas of economic development and conservation projects. It also suggests broad-scale changes that are in progress for rural communities experiencing landscape conversion, and the potential difficulties of these changes for resilience and adaptation.

\section{BACKGROUND}

In the forest zone of West Africa, natural resources acquired through hunting and gathering provide income, food, building materials, tools, and medicine to rural households, as well as supply markets in urban centers (Asibey and Beeko 1989, FAO 1990). In addition to their impact on household economies, West African forests help define communities and cultures, appearing in music, story, and spiritual beliefs (Martin 1991, Decher 1997). However, the region is in an "advanced stage of forest depletion," and from 1981-1990 exhibited the highest rates of deforestation in Africa, estimated to be 1\% per year (FAO 1993). The loss of forests has multiple causes, including logging for tropical timber, clearing of forest land for cultivation, and

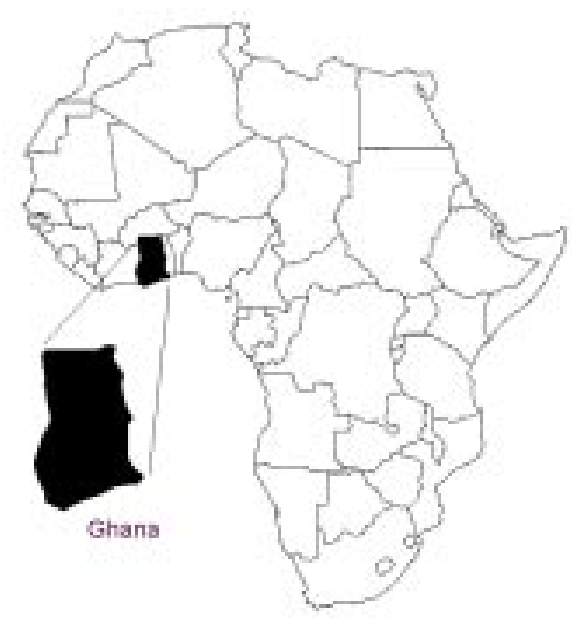

Fig. 4-1. African continent, with Ghana enlarged. slash-and-burn agriculture. In addition to the felling of trees, intense hunting pressure to satisfy local and national markets with bushmeat (wild game) raises concerns about wildlife depletion and concomitant degradation of standing forests (Ntiamoa-Baidu 1997).

For rural villagers in Ghana (Fig. 4-1), resilience in the face of crisis has become an essential survival skill (Dei 1988), as forest resources have been depleted (Wagner and Cobbinah 1993). Indeed, most remaining large forests in southern Ghana are those that receive 
formal protection as forest reserves or national parks (Fig. 4-2). The loss of a forested landscape and its resources present distinct options: Villagers can adapt to different products or substitutes, or they can make do with less. In the cases of extreme depletion of resources, they also move (Amanor 1994). Though

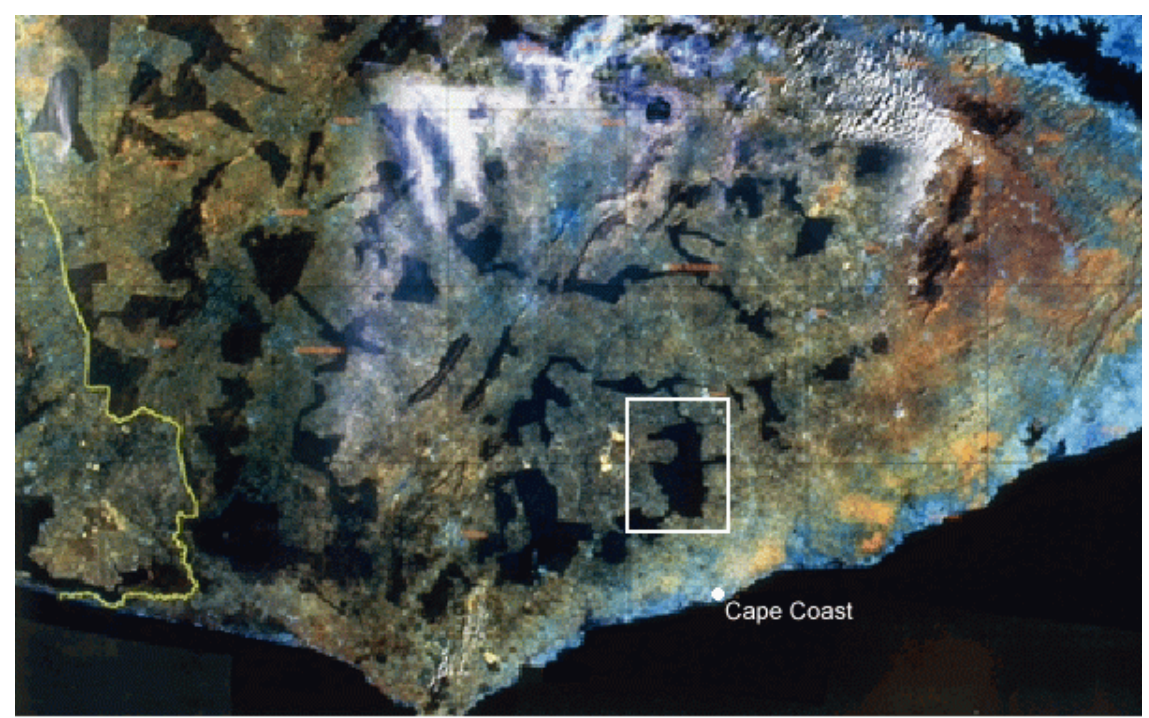

Fig. 4-2. Satellite mosaic image ${ }^{1}$ of southern Ghana, with Kakum Conservation Area in rectangle. Dark images north of the coastline are forested areas.

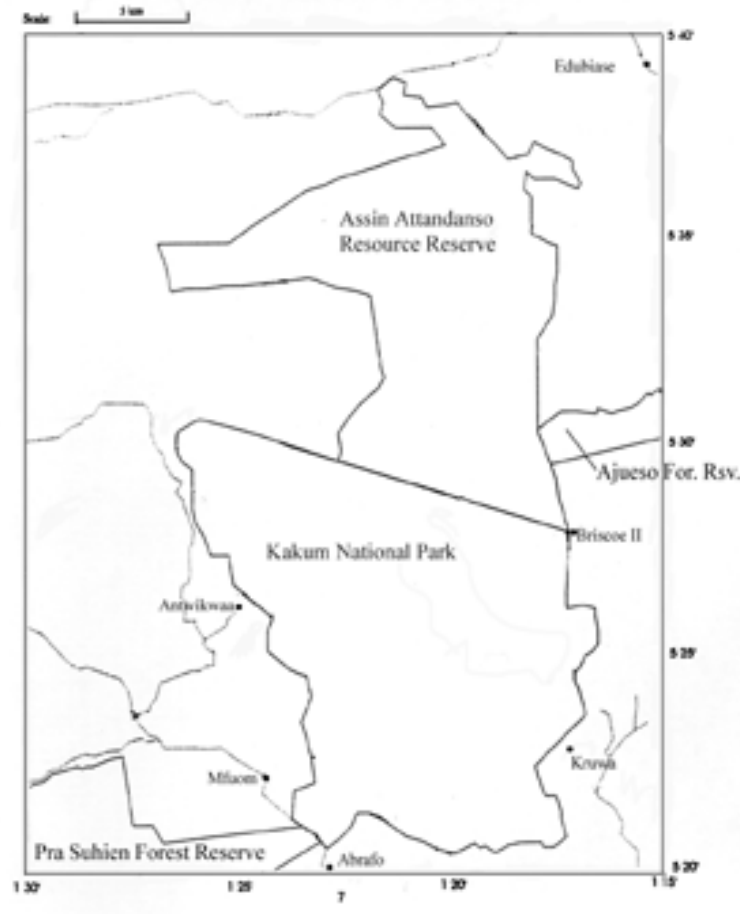

Fig. 4-3. Kakum Conservation Area, Ghana. Modified from Dickinson (1996). dramatic changes in Ghana's forest have occurred in the 20th century, they often occur in any given area over several decades (and two or more human generations), and Ghanaian communities' necessity to adapt to a reduced resource base becomes a survival skill which is ingrained and continuous, rather than a response to any one significant event.

In 1989, two national forest reserves in Ghana were re-classified by the Ghanaian government to become a Game Production Reserve (later changed to a Resource Reserve) and a National Park, respectively (Fig. 4-3). While under Forestry Department management, the forest reserves had been heavily logged by timber companies, and

${ }^{1}$ Landsat TM (Band combination 457) image mosaic compiled by GISL Limited. The imagery dates from 1989-91 and has been enhanced scene by scene to maximize discrimination of forest areas. The mosaiced scene in this atlas is a sub-sampled image with an effective spatial resolution of $110 \mathrm{~m}$; this was used to derive the boundaries to the forested areas. Copyright GISL 1999. gisl@gisl.co.uk. www.gisl.co.uk 
extensively used by generations of local residents for hunting and gathering. Under new management by the Ghana Wildlife Department, the two protected areas were jointly managed as the Kakum Conservation Area (KCA), and designated to be part of a new economic development project which would be focused on international tourism. Logging, hunting and gathering were banned in the reserves in order to promote tourism through biodiversity conservation, as part of the national strategy for the Central Region. Development of the Kakum Conservation Area rain forests was complemented with the restoration of coastal forts and castles, and resort plans for undeveloped beaches. While local communities around KCA welcomed the income potential offered by an incipient tourist industry, denial of access to traditional forest resources created tension between villagers and park staff. The U.S. Agency for International Development, which supported the restoration of the historic buildings and biodiversity conservation in KCA, requested in 1994 that a study be conducted in order to better understand management issues relating to community relations and traditional use of forest resources.

The KCA comprised the last large remaining block of forest in the study area, since non-reserved forests had been felled or heavily degraded during prior decades, primarily for timber and the expansion of cocoa production. Had extensive forests outside the 345-sq. kilometer KCA still existed, the impacts of the new conservation area would have been somewhat diluted. Instead, KCA represented the last significant option for harvest of wild products for most communities in the area, and the impacts were strongly felt. Thus the elimination of the Kakum forest was a significant, but singular, event in a long series of more incremental forest losses in the region. The impacts of forest loss felt in the KCA study area reflected changes that occurred more widely, but slowly, in the forest belt of southern Ghana since the 1960s. The abrupt nature of "loss" of the KCA forest -- at least in terms of access to its wild products -- permitted the study to detect a wide range of impacts that have been broadly felt throughout the Ghanaian landscape but which elsewhere were more gradual, and perhaps more difficult to pinpoint at a certain time with a specified block of forest land. 


\section{METHODS}

A survey of villages and households was conducted in Ghana's Central Region from January to April of 1994 to assess the impact of the establishment of the two national reserves on local villagers and recommend steps for resolving problems (Bailey 1995). The study area was the environs of Kakum National Park and adjacent Assin Attandanso Resource Reserve, jointly managed and collectively referred to as Kakum Conservation Area (KCA), Kakum, and "the park." Interviews with 522 households were conducted by a team of 8 Ghanaian researchers.

Census data proved to be an inadequate source of information for developing a sampling protocol in the region, since many villages in existence in the region were not included on census lists. Moreover, for those villages that were listed, population sizes from census data were not consistent with actual population levels. Therefore, prior to undertaking household surveys, the team conducted a pre-survey village assessment in 54 villages located in the KCA environs (see Appendix 4-A). The assessment included relative estimates of villages' populations, as well as basic questions regarding access to markets and forest resources, infrastructure for water, education, and health care, and history of the area. The pre-survey was also used to meet with village leaders according to local protocol, introduce the project, and request support from the villages for the upcoming household surveys. Furthermore, discussions with opinion leaders in the villages raised key issues that would be explored with questions in the household survey instrument.

Working with a map of the KCA boundary, researchers marked off intervals around the border that were separated by about 4 miles. Each point on the boundary became a potential starting point for a "corridor," which was followed from its starting point for a distance up to 7 miles from the park toward the nearest market. Researchers started at the village nearest the park boundary point, and upon completion of interviews followed villagers' directions toward the next village en route toward the market. It was anticipated that the flow of goods from the forest to its market end point could be traced. The resulting design was of a hub with the park at the center from which radiated spokes. Each community along each spoke was sampled in proportion to its size. 
Following completion of study design, a training and orientation session was held for the survey team members. Surveying and the study design were discussed, and Ghana Wildlife Department (GWD) personnel (charged with administration of national parks) presented information on conservation and resource law. Previous research on non-timber forest products was reviewed (Asibey 1974; Falconer and Arnold 1991; Falconer 1992; Ntiamoa-Baidu 1992). A semistructured household survey instrument was developed, with participation from GWD as well as team members. However, due to tension with villagers it was determined that GWD personnel would not participate as interviewers. Translation of the questions into Twi, the dominant language, and Fante, were also discussed. Ultimately, the survey dealt with questions about markets, health care, diet, land tenure, household expenses and income, family structure and origin, agricultural practices, environmental perceptions, and forest products, access, and activities (Appendix 4-B). The draft survey instrument was tested in 2 villages with 10 households prior to initiation of the formal study, then finalized for clarity and ease of response.

From the pre-survey, it had become clear that forest access and the creation of the KCA were sensitive issues. Questions relating to forest access and use of products were clearly delicate; some otherwise cooperative respondents refused to answer certain questions on the survey, for fear of prosecution. Thus response rates varied considerably among survey questions. It was decided that in addition to the household surveys, 6 focus group interviews (Patton 1990) with opinion leaders, hunters, and herbalists would also be held. Group discussions were more freeranging, less personal, and therefore less intimidating to individuals than face-to-face interviews. In fact, many village "opinion leaders" welcomed the opportunity to be interviewed.

Sample sizes for responses also varied according to the question format. Several questions permitted open responses, or generated short lists. Thus the question, "What is your preferred bushmeat?" might elicit names of three or more wild species. In the case of multiple-response questions, the first three items listed were selected for analysis, creating the possibility that the 522 households could generate 1,566 responses. Interview times ranged from 14 to 160 minutes, with a mean time of just over an hour (69 minutes, 20.37 s.d.). Households, which are a largely Western construct (Hill 1986), were functionally defined as those clusters of related 
individuals who pooled labor and resources and ate from the same cooking pot on a regular basis.

\section{RESULTS}

\section{Household and Community Composition}

Households in the KCA zone (Table 4-1) ranged in size from 1 to 25 family members; the mean size was almost 6 individuals. Household size was not a constant throughout the year: over a third of households reported that family members were absent either at the time of the surveys or at other times during the year. Absentees were either children, enrolled in boarding school, or adult children of heads of households who were working away from home. Adult absentees often migrated to urban areas, and remitted income to their households. Males were principal respondents in $86.6 \%$ of the surveys, though spouses were often present.

Table 4-1. Household and community characteristics in villages surrounding Kakum Conservation Area, 1994.

\begin{tabular}{lrl}
\hline \hline Characteristic & Percent responses & Comment \\
Family size & 5.75 (mean) & \\
Absentee household members & $35.1 \%$ of households & school, work \\
Religion & Christian $=85.1 \%$, & \\
& Moslem $=7.3 \%$ & \\
Water & Bore holes $=40 \%$ & multiple sources; no homes with \\
& Park source $=46 \%$ & running water \\
Transportation & "footing" $=79.3 \%$ & \\
Distance to market & 2.27 miles (mean) & \\
Newcomers to KCA & $45.8 \%$ & \\
Newcomers since 1959 & $89 \%$ & \\
Reason for newcomers moving to KCA & Farming: 53.3\% & \\
& Family: $24 \%$ & \\
Farming households & $89.8 \%$ & Primary or secondary occupation \\
Sent money to home village (away from & $30.4 \%$ & \\
village of residence) & & \\
\hline
\end{tabular}


Homes in the survey area were principally of wattle-and-daub wall construction typical of rural communities in Ghana's forest zone (Faculty of Architecture 1978), with compacted earth floors and roofs of Raphia palm thatch. A home could consist of a single structure, or a compound (usually walled or fenced) with multiple rooms constructed within its perimeter. Houses in some of the larger towns had corrugated metal roofing, but respondents without metal roofs said its cost was prohibitive. At the time of the survey, no houses had running water. Bore holes (wells covered with pump) provided drinking water to $40 \%$ of the communities, but due to its distinctive taste many residents still preferred to drink surface water from streams. Some houses had outdoor pit latrines in their compounds or nearby. Community latrines and KVIP toilets were in use in some communities as well.

Ownership of private vehicles -- cars, trucks, motorcycles, or bicycles -- was extremely rare. "Footing" was the standard mode of travel for households. Distance to nearest weekly markets averaged 2.27 miles, but many respondents also went weekly (or more often if they were selling produce) to larger daily markets farther away in Cape Coast or Foso. In these cases residents walked to a main road to hail a mini-bus to market, or vehicles would pass through the villages to pick up vendors and buyers.

Only a few houses in one community (Edubiase) had electricity at the time of the survey (though since 1994 rural electrification programs have begun to reach more of the communities). Radios and tape players were uncommon because batteries were viewed as too expensive. Light was provided by kerosene lanterns. Fuelwood or charcoal were used for cooking.

Household economies were very locally based, not entirely cash-dependent, and functioned with limited imports and surplus. Western-style shirts, pants, and dresses were commonly worn; they were generally second-hand, purchased in markets. Wrist watches and eyeglasses were rarely worn. Farming tools consisted of cutlasses (machetes) and hoes; no power tools or machinery were used. Cutlasses and hoes were forged locally for about 1,000 cedis each ( $\$ 2.50$ in 1994), or commercially produced and sold for about 3,500 cedis each. Granaries in compounds were used to store maize. Livestock (goats, sheep, and chickens), if kept, were most often free range. 
Human communities were not evenly distributed around the KCA. An estimated $68 \%$ of households in the study area were found in a southern tier. This tier, which included 3 communities with estimated populations greater than 1,000 (Mfuom, Jukwa, and Kruwa), had absorbed the largest influx of settlers since 1959 (Fig. 4-4), but the percentage of newcomer households compared to lifelong residents remained a minority $(<37 \%)$. Communities on the western side of the park such as Antwikwaa and Aboabo were comprised largely of settler households. Indeed, only $5.3 \%$ of households along the western side of the park reported that

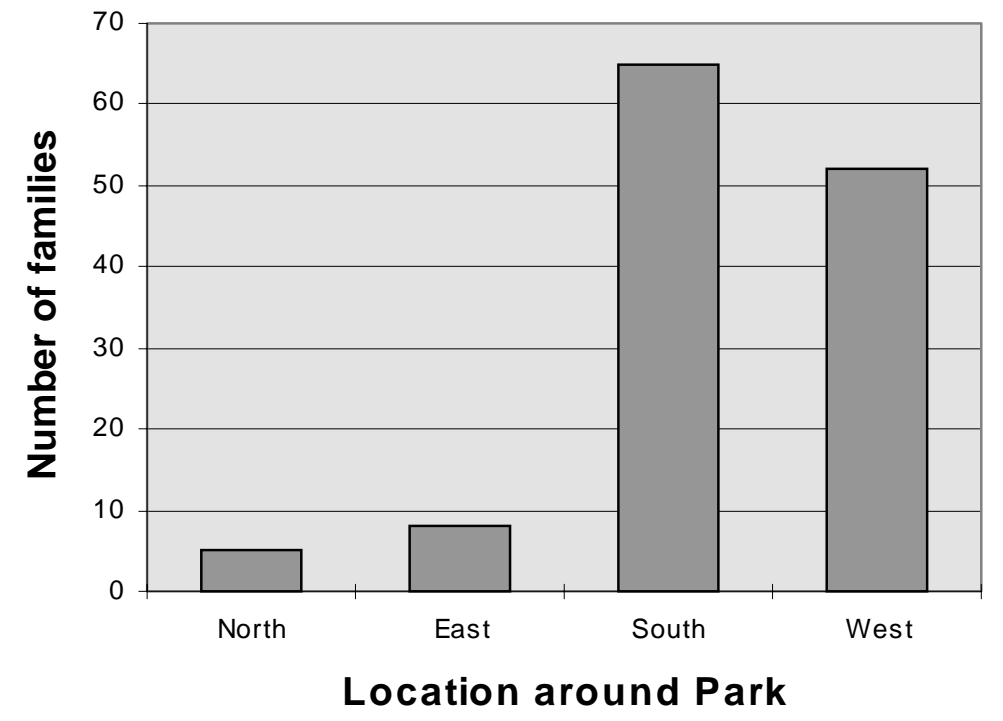

Fig. 4-4. Distribution of settler families arriving since 1959, Kakum Conservation Area $(n=130)$. they were native to the villages in which they lived.

Migration to the KCA region was significant in recent decades. Nearly half of heads of households reported that they or their families had moved to $\mathrm{KCA}$, though $77 \%$ had come from other villages or towns within the Central Region. Of the newcomers, $89 \%$ had arrived since 1959; the rate continued to grow through 1993 (Fig. 4-5). Respondents indicated a variety of reasons for moving to the area, though the principal reason was farming, followed by family already living in the area. During interviews, respondents frequently referred to their "home village", and $30.4 \%$ reported that they sent money back to family members there.

Farmers reported that soils and climate around the KCA were known to be favorable for cocoa cultivation. In addition to the area's suitability, however, government incentives encouraged the expansion of cocoa cultivation by arranging for credit for land purchase or lease, subsidizing the costs of pesticides, and offering price supports to maintain incomes (The Cocoa Sector 1983, Dei 
1994). These incentives were directed toward cocoa largely because of its value as an export commodity which generates hard currency, which is essential for national development.

Furthermore, as the government of Ghana adopted structural adjustment measures for its economy, agencies were downsized through a series of "retrenchment exercises." Those who were in the "redundant labor"

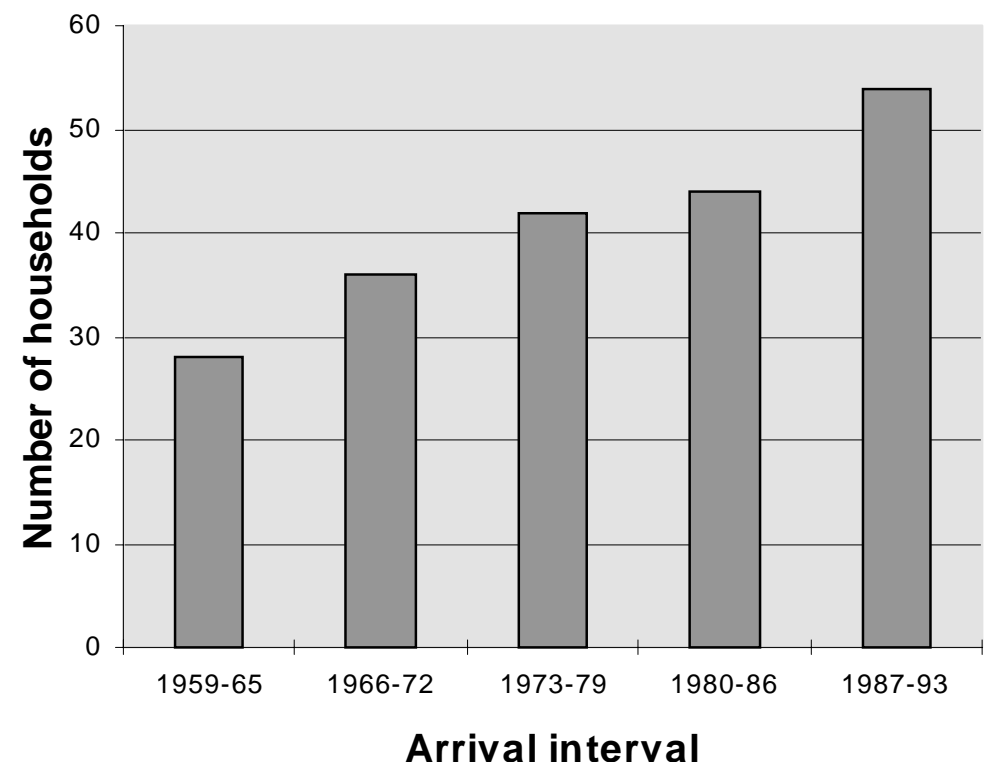

Fig. 4-5. Settler arrivals to Kakum Conservation Area since 1959. force were provided with incentives to return to the land to farm cocoa (Dei 1994, Mills 1994).

\section{Forests: Costs and Benefits}

The KCA forest served local residents as "grocery, hardware store, pharmacy, school, playground, and insurance agent" for many years (Bailey and Mbir 1997). Communities around KCA had used the forest regularly: $76.1 \%$ of households acknowledged that they had depended on products from the reserve in the past, either through direct exploitation or through purchase of or trade for forest products. In addition, villagers cited specific groups the forest served, such as youth, who derived "employment" from the forest with products gathered and sold. The KCA forest provided a range of products and services that were not available from farms, and thus subsidized local lifestyles and livelihoods. Dei (1988) cites the "safety net" function provided by forest resources during times of crisis in Ghanaian villages. In his study, many forest products were relatively rarely exploited during years of abundant rainfall and successful farming seasons. However, the availability of alternative forest resources permitted villagers to adapt to crisis and absorb returning migrant workers during the harsh 1982-83 drought by drawing on little-used contingency resources during a time of hardship (Dei 1989). In contrast, the villagers from KCA were accustomed to ease of access and an active harvest of wild products until the ban 
was imposed in 1989 (Table 4-2).

Table 4-2. Forest use and household economies in Kakum Conservation Area environs, 1994.

\begin{tabular}{lrl}
\hline Characteristic & Response \% & Comment \\
Regularly used forest & $76.1 \%$ & Prior to park establishment \\
Access to other forests outside park & $41.2 \%$ & $\begin{array}{l}\text { Concentration in southern tier } \\
\text { around KCA }\end{array}$ \\
Purchase forest products at markets & $80.5 \%$ & Since establishment of park \\
Purchase fuelwood & $6.7 \%$ & Gathered from farms or "bush" \\
Use local "bush" remedies as medicine & $63 \%$ & $\begin{array}{l}\text { Prepared at home or purchased } \\
\text { from native doctors }\end{array}$ \\
\hline
\end{tabular}

When asked if they had access to other forest patches outside of KCA, $41.2 \%$ of respondents responded affirmatively. Two national forest reserves adjoin KCA (see Fig. 4-2). The larger of the two, Pra Suhien, is located near the large village of Mfuom, and offers nearby residents an alternative source for the harvest of products from the wild. Unfortunately these forests are not widely distributed: Of those who responded that other forest patches were available, $79.2 \%$ were from the southern tier, and 53.5\% lived in Mfuom. Figure 4-6 shows percentages of households in each direction around KCA who acknowledged access to other forest resources Though extensive forest patches with a full range of resources that could substitute for the KCA forest were not widely available, the landscape around KCA was not completely converted to fields. While cocoa cultivation stimulated the felling of areas of intact tall forest, it also conserved remnants of those stands, since KCA farmers cultivate cocoa trees under shade. These patches were frequented by villagers, who continued to use them to search for wild products such as medicinal plants, snails, and basketry materials. The patches were also important as sources of fuelwood. Few households indicated that they bought fuelwood; most claimed to continue to find adequate fuelwood resources from their farms or from "bush" in the area.

However, pressure on other forest sites increased as foragers turned away from KCA, and resources in them became more scarce, according to villagers. Since the establishment of the 


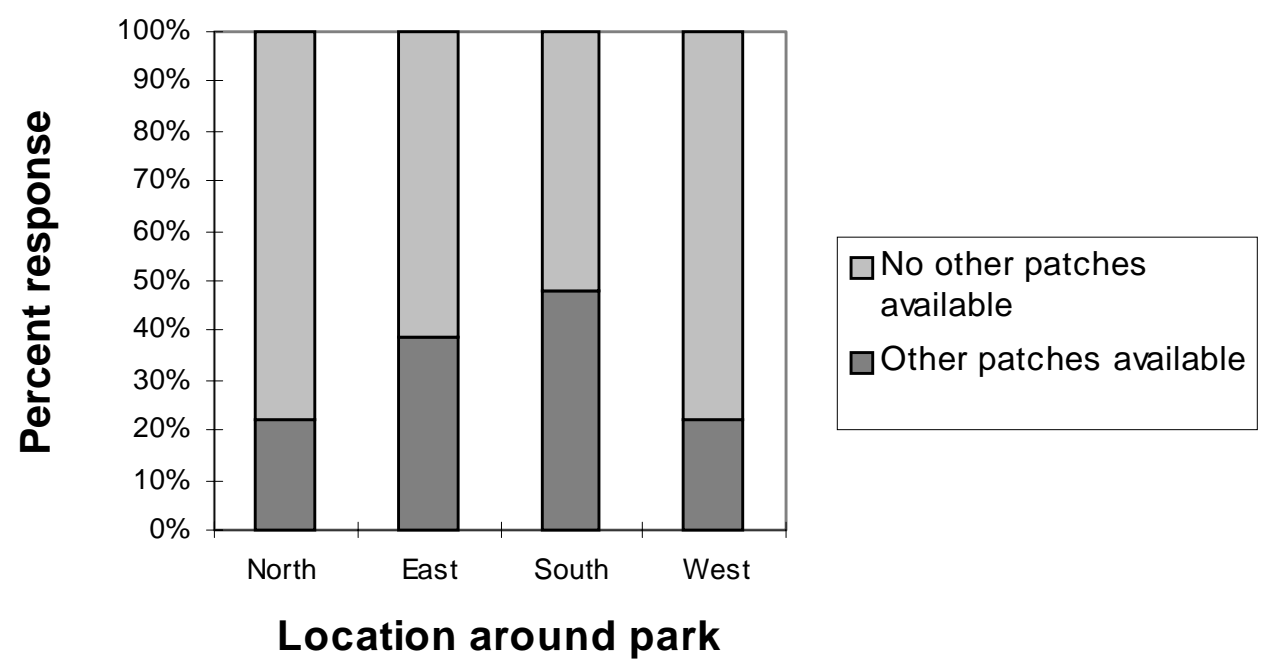

Fig. 4-6. Access to alternative forest patches around KCA, 1994.

park, $80.5 \%$ of households reported, they had begun to purchase forest products at markets. This represented a shift in the form of exchange for many villagers, who had been able to obtain products from KCA for "free" (none counted their time and effort for harvest as costs), but now required cash to purchase them. For many, KCA had also been a source of income, since many of the products harvested were sold (as well as used at home). Thus the ban on access to the park was doubly painful: It not only eliminated access to products which were sources of income, but it also increased cash needs for buying those products for home use. 
Table 4-3. Adaptations to loss of access to forest products from Kakum Conservation Area.

\begin{tabular}{ll}
\hline \hline Adaptation & Example \\
Illegal gathering in reserve & Medicinal plants \\
$\begin{array}{l}\text { Hunting or gathering of same items from } \\
\text { other forest patches }\end{array}$ & Cane for baskets from adjacent forest reserves \\
Purchase of same resources from markets & Snails, mushrooms, medicinal plants \\
Use of substitutes & Livestock or fish instead of bushmeat \\
Purchase of manufactured substitutes & Plastic bags instead of wrapping leaves \\
Intensified managed production & Snail rearing \\
Acceptance of loss & Some bushmeat species \\
\hline
\end{tabular}

Residents near Kakum described a range of strategies for adapting to loss of forest products (Table 4-3). Plant products and their uses which were most widely identified as significant losses included Raphia (palm leaves) for roof thatch, cane for baskets, sponge for bathing and cleaning, pestles for pounding "fufu" (a starchy dietary staple of cassava and other tubers), and medicines. Animal products primarily served as bushmeat, either for personal consumption or sale, though some species' hides also had been used for drum heads, and feces of some species were used in medicinal preparations.. Some respondents felt that certain plant and animal products had no substitutes (Tables 4-4 and 4-5).

Villagers were also asked to list disadvantages of the KCA forest. The lack of access to medicines since the creation of KCA was of concern to $44 \%$ of households. Of all households, $63 \%(n=522)$ reported that they used local remedies prepared from forest or "bush" (uncultivated) resources, either prepared by themselves or purchased from a native doctor. Modern pharmaceuticals were cited as expensive and therefore out of reach for villagers, as was a disdain for having to purchase something that could be obtained and prepared by oneself. In advocating for continued access to the park, villagers also lauded the greater good that could be derived from gathering in the forest: "The government should immediately allow herbalists to use the plants in the forest, for the AIDS drug could be relaxing there." 
Table 4-4. Plant product substitutes reported by KCA respondents 1994 (figures indicate percentages of respondents for each product and substitute category). ${ }^{\text {a }}$

\begin{tabular}{|c|c|c|c|c|c|c|}
\hline Plant Product & $\#(\mathrm{~N})$ & No subst. (\%) & Other plant spp. & $\begin{array}{l}\text { Manufac- } \\
\text { tured item }\end{array}$ & Fish & $\begin{array}{l}\text { Same, } \\
\text { but buy }\end{array}$ \\
\hline Raphia & 225 & 7.1 & 41.8 & 43.1 & 0 & 8.0 \\
\hline Cane & 222 & 21.6 & 35.6 & 30.6 & 0 & 12.2 \\
\hline Sponge & 164 & 9.1 & 4.3 & 67.1 & 0 & 19.5 \\
\hline Pestle & 129 & 65.1 & 3.1 & 0 & 0 & 31.8 \\
\hline Mortar & 88 & 63.6 & 3.4 & 1.1 & 0 & 31.8 \\
\hline Chewstick & 88 & 17.0 & 17.0 & 50.0 & 0 & 15.9 \\
\hline Wrapping leaves & 37 & 13.5 & 8.1 & 64.9 & 0 & 13.5 \\
\hline Mushrooms & 118 & 63.6 & 2.5 & 0 & 16.9 & 16.9 \\
\hline Eshe & 26 & 15.4 & 3.8 & 65.4 & 0 & 15.4 \\
\hline Medicines & 122 & 16.4 & 0.8 & 76.2 & 0 & 6.6 \\
\hline All Plant spp. & 1219 & $27.7 \pm 2.11$ & $17.2 \pm 1.78$ & $37.2 \pm 2.28$ & $1.6 \pm 4.71$ & $16.2 \pm 1.74$ \\
\hline
\end{tabular}

Table 4-5. Bushmeat substitutes reported by KCA respondents 1994 (figures indicate percentages of respondents for each product and substitute category). ${ }^{a}$

\begin{tabular}{lcllllll}
\hline \hline $\begin{array}{l}\text { Animal } \\
\text { product }\end{array}$ & $\begin{array}{c}\# \\
(\mathrm{~N})\end{array}$ & $\begin{array}{l}\text { No sub- } \\
\text { stitute }\end{array}$ & Fish & $\begin{array}{l}\text { Other } \\
\text { bushmeat }\end{array}$ & $\begin{array}{l}\text { Domestic } \\
\text { stock }\end{array}$ & $\begin{array}{l}\text { Vegetable } \\
\text { proteins }\end{array}$ & $\begin{array}{l}\text { Now buy } \\
\text { same }\end{array}$ \\
\hline Grasscutter & 200 & 6.5 & 49.5 & 3.0 & 35.5 & 0 & 5.5 \\
Bush Pig & 146 & 10.3 & 38.4 & 4.8 & 43.2 & 0 & 3.4 \\
Monkey & 95 & 25.3 & 42.1 & 5.3 & 26.3 & 0 & 1.1 \\
Snail & 276 & 36.5 & 43.7 & 3.2 & 2.5 & 0 & 13.7 \\
Bush Rat & 132 & 16.7 & 42.4 & 3.8 & 28.0 & .8 & 8.3 \\
Duiker & 88 & 20.5 & 47.7 & 4.5 & 22.7 & 0 & 4.5 \\
Antelope & 55 & 12.7 & 45.5 & 21.8 & 20.0 & 0 & 0 \\
All & 992 & $20.2 \pm 2.10$ & $44.3 \pm 2.59$ & $4.8 \pm 1.11$ & $23.6 \pm 2.22$ & $0.1 \pm 0.52$ & $7.1 \pm 1.34$ \\
Bushmeat & & & & & & & \\
\hline
\end{tabular}

a $90 \%$ Confidence intervals are listed for substitute categories 
Villagers recognized non-monetary benefits derived from the KCA forest. Its favorable impact in moderating local climatic conditions was listed most often, by $41.8 \%$ of households. The forest was credited with enhancing agricultural production by lessening temperature extremes, serving as a wind break, and providing consistent rainfall. "If you destroy the forest it will prevent rain from falling," explained one respondent. The surface water from KCA's streams and springs was also important to communities, since $46 \%$ of households reported their water sources came from the park. Those who entered to fetch water were permitted to do so by park guards. The significance of KCA's contribution to water supplies (as well as health) in the wider region is difficult to estimate; it is certainly undervalued within the country in comparison to activities that earn foreign exchange. However, the creation of the forest reserves in the 1920s and 1930s was determined largely on the basis of watershed protection, and KCA continued to protect the headwaters of rivers that supplied residents from KCA south to Cape Coast with their water (Kpelle 1993).

The forest landscape of Ghana is also dotted with numerous sacred groves (Decher 1997; DormAdzobu et al. 1991), and villagers reported that KCA also contained religious shrines of importance to their communities.

\section{Farms: Crop raiding}

KCA villages were closely tied to the land, with $89.8 \%$ of all households indicating that they owned or worked on farm land, or both (Table 4-6). As with other Ghanaian villages (Dei 1989), households had multiple sources of income. Individuals who farmed might also be involved in trading, or teachers might also have small farm plots which supplemented their salaries. Farming was described as the primary occupation for at least one of the principal income earners in $71.8 \%$ of households. Cocoa was farmed by more than half of all households. Other cash crops included citrus and oil palm. Food crop farmers (predominantly women) raised food for the family to eat, as well as to sell at market. Other primary occupations included trading and teaching. 
"Total protection [of the forest] has raised animal populations, thus destroying our crops," reported one villager whose sentiments were echoed in all villages. Animal damage to crops was widespread: Of 461 households reporting damage to crops, 445 (96.5\%) indicated that wild vertebrate species caused crop losses. Disease and insect damage were also prevalent. Grasscutters (Thryonomys swinderianus), a large rodent species valued for its flesh, were reported to be a problem by $75.1 \%$ of households, followed by squirrels, elephants, and monkeys. Domestic livestock (goats, sheep) were mentioned by $2.2 \%$ of households reporting damage. Grasscutters are not strictly forest dwellers, but more often frequent border of agricultural lands, fields, and second growth (Schrage and Yewadan 1992). However, a ban on hunting within 2 kilometers of the forest was imposed by Ghana Wildlife Department, and villagers therefore viewed grasscutter damage as an impact of forest protection. "Formerly, the farms were not being destroyed. The elephants and bush pigs have increased and so they destroy our farms which was not the case before," complained one respondent. Cassava, plantain, maize, cocoyam, oil palm, cocoa, and citrus crops were all reported to be damaged by animals.

Table 4-6. Farm-related characteristics reported by residents in environs of Kakum Conservation Area, Ghana, 1994.

\begin{tabular}{lrl}
\hline \hline Characteristic & Percent responses & Comment \\
Forest provides climatic benefits for & $41.8 \%$ & Moderates temperature, provides \\
farming & rainfall, offers windbreak \\
Primary occupation & Farming: $71.8 \%$ & Primary occupation for either head \\
& Trading: $4.7 \%$ of household or second in \\
& Teaching: $2.9 \% \quad$ command \\
Cocoa farming & $54.6 \%$ & \\
Animal damage caused crop losses to & $96.5 \%$ & \\
farms & & \\
Types of animal damage & Grasscutter: $75.1 \%$ & \\
& Squirrels: $22.4 \%$ & \\
& Elephants: $19.5 \%$ & \\
& Monkeys: $18.7 \%$ & \\
& Livestock: $2.2 \%$ & \\
\hline
\end{tabular}


An increase in crop damage by animals was not necessarily due to increases in animal populations. Without the noise disturbance from logging activities and the reduced hunting pressure in and around the forest, crop raiders such as monkeys and elephants could have become less fearful of venturing beyond the park borders; elephants may also have been attracted to new growth in heavily logged sites near the forest edge (Barnes et al. 1995, Struhsaker et al. 1996). These factors, combined with an increase in settlers' farms near the forest, increased the likelihood that crops would be damaged. Proximity to the forest was clearly a risk in terms of elephant damage: $80.9 \%$ of farmers reporting elephant damage farmed within one mile of the forest, far exceeding the proportion of farms located in the same area (Table 4-7). Crop raiding by animals was not viewed as merely an annoyance, but as a serious threat to villagers' livelihoods.

Table 4-7. Incidence of crop damage to farms by elephants as reported by farmers in KCA, 1994.

\begin{tabular}{lll}
\hline $\begin{array}{l}\text { Farm to forest } \\
\text { distance }(\mathrm{mi})\end{array}$ & \multicolumn{2}{l}{$\begin{array}{l}\text { Farms suffering } \\
\text { elephant damage }\end{array}$} \\
& Yes & No \\
\hline $0-1$ & 72 & 101 \\
$1.1-2$ & 10 & 52 \\
$2.1-3$ & 4 & 39 \\
$\geq 3.1$ & 3 & 187 \\
\hline
\end{tabular}

${ }^{a}$ Differences among occurrences of damage for different distances from forest are significant $(G=116.3, p<.000)$.

\section{Food}

The differences between villagers' dietary practices and their preferences, particularly for protein, surfaced in interviews as important themes connected to changes in the forest (Table 4-8). Social and economic changes in Africa have been documented elsewhere as causing shifts in dietary sources and habits (Tripp 1992). One notable effect of the ban on forest access was a change in sources of dietary protein. Of 520 households listing types of protein that made up their diets, $81 \%$ listed fish. When asked to list up to 3 preferred protein items, striking differences appeared. Many households listed multiple species of bushmeat as their preferences: $73.2 \%$ of all 
responses identified bushmeat species, while only $4.5 \%$ indicated fish (Fig. 4-7).

Table 4-8. Food and dietary characteristics as reported by villagers in environs of Kakum Conservation Area, 1994.

\begin{tabular}{lrl}
\hline Characteristic & Response percentages & Comment \\
Protein sources & Fish: $81 \%$ & Respondents indicated fish \\
& Livestock: $47.7 \%$ & consumption had increased since \\
Beans: $39.6 \%$ & park establishment \\
Bushmeat: $26.2 \%$ & \\
Protein purchased at markets & $58.6 \%$ & \\
$\begin{array}{l}\text { Protein acquired from farm or } \\
\text { bush }\end{array}$ & $30.9 \%$ & \\
\hline
\end{tabular}

Fish (generally dried or salted) was not a new item in local diets, but interviews indicated that more fish were being consumed as a result of the ban on access to the forest. The topic also emerged in the context of commodities and substitutions. "Presently fish prices are too high and most farmers cannot afford it, yet animals roam in the bush freely," stated one resident. In describing products that they had formerly had access to from the KCA forest, respondents were asked to indicate what substitutes, if any, existed for these products. Fish were indicated as substitutes for bushmeat by $44.3 \%$ of all reporting households $(n=329)$. Domestic livestock species were used as substitutes by $23.6 \%$; and $20.3 \%$ of households reported that for certain species, no substitutes existed. More detailed information on substitutes for animal products is in Table 4-5.

Snails were identified most as those products for which there were no substitutes, and merit special mention. Their use as a food item was substituted with fish by $43.7 \%$ of respondents. However, the value of snails was multi-faceted: not only were they highly prized in stew, they were also a source of income. Furthermore, the principal gatherers were women and children, who had less access to financial resources than men, and therefore were significantly affected by loss of access to this product. And their value was not only culinary, nor economic: snail gathering was viewed as an important seasonal activity pursued by family groups working together in the forest. Its significance as an activity was highlighted in focus group discussions, where the gathering of snails (as well as some other products) was described as an "occupation" 
(of time and season) for youth: it gave them something to do, and was a clearly defined role in the community for a particular age cohort. One respondent emphasized that communities should have access to the forest "so as to get the youth employed."

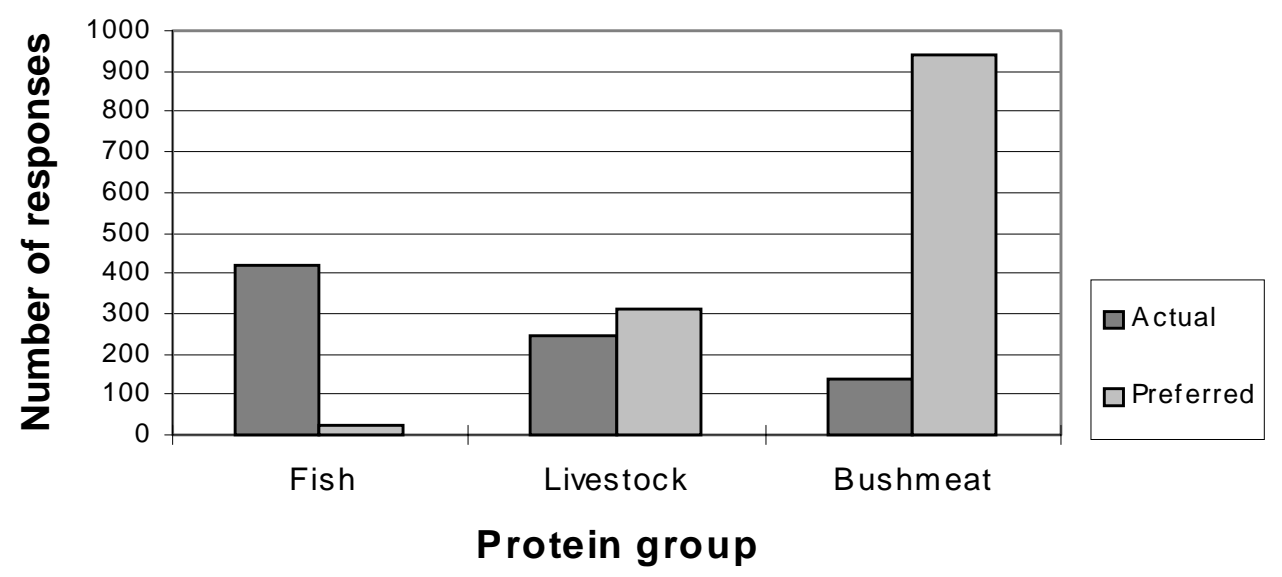

Fig. 4-7. Actual and preferred dietary meat protein among KCA respondents, 1994.

With the lack of access to resources created by the park establishment, over half of all respondents indicated an increase in purchasing protein sources at markets, while $30.9 \%$ reported protein sources acquired from farm or bush (by illegal trapping or hunting). As with the denial of access to plant materials, the inability of villagers to acquire bushmeat from the forest affected not only their personal consumption, but also their income, and their sense of job security. Respondents identified the forest environment as part of their domain: "The sea has not been banned for fishermen; how come the government should ban the farmers from using the forest?" asked one villager.

\section{CONCLUSIONS}

Loss of forest -- either through felling of forest stands or by banning access -- has far-reaching, multiple impacts on the local economies and cultures of forest-dependent households and 
communities that can easily be overlooked in large-scale development projects (Table 4-9). Ideally, economic development projects increase income to residents, compensating them for economic losses. However, loss of forest access is especially difficult for communities in which economies are not strictly cash-based, as in the Kakum area. In these cases, where forest products serve as currency, development projects can impose hardships by stimulating a need for cash to compensate for "value-subtracted" products, and increase risk as well as threaten stability as alternatives and substitute goods are sought. Furthermore, project evaluations based on strict income generation criteria are likely to overlook cultural and non-priced values that weave the cultural fabric of communities. Overall, loss of access to forest resources in rural communities thins the available "cushion" of locally-based economic contingency strategies among those who are already somewhat marginalized from national economic structures. Such strategies are important in Ghana's villages, since they permit communities to re-absorb urban migrants during economic downturns, weather the vagaries of climate, and maintain community cohesion through cooperation and pooling of resources (Dei 1988, 1992, 1994).

Table 4-9. Household and community impacts of loss of access to forest resources.

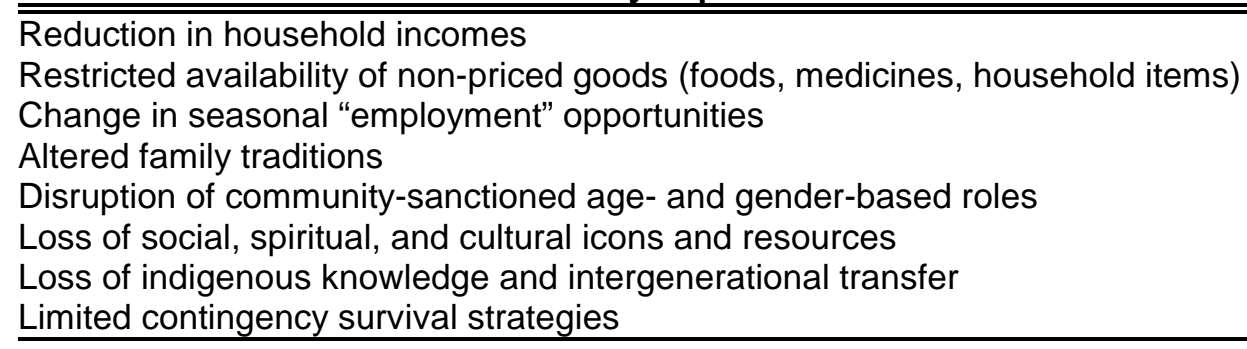

The KCA study illustrated a wide range of deprivations and hardships largely because the "loss" of the forest was widespread and sudden. A similar dynamic has taken place throughout the forest zone of southern Ghana over a longer period of time as extensive forest conversion to commercialized agriculture and logging took place, though the changes and adaptations to them were more incremental. In addition, increases in pressure due to population growth put nonprotected forest resources at risk. Indeed, such dynamics were likely to have been underway already in KCA, where forest resources in the park had been heavily degraded by logging and hunting before protection status was conferred (Struhsaker 1993). Furthermore, forests outside the reserve also were much reduced (Barnes et al. 1995). Without counting natural population 
growth, the KCA had experienced a near-doubling of human population due to agriculture-driven in-migration during the previous 30 years. In the absence of strict protection status, the forest could have remained standing, but heavy pressure from hunting and gathering by the increasing human population would likely have rendered it impoverished of many of its biological resources. The absence of historic biological information from the forest precludes knowledge of what might already have been lost.

Economic development projects stimulated by national governments and funded by bilateral or international agencies tend to be export-driven (Dei 1992, Amanor 1994). Whether the exports are tangible international commodities such as timber or cocoa, or less tangible foreign exchange earners such as tourism, the strong focus brought to bear on one or few products can easily swamp small-scale, locally-based economic activities that contribute to stratified, diverse local economies. The mono-economies that result from such development projects can overshadow and outprice lesser but more diverse economic activities. The economic projections around which such projects are designed are ill-equipped to assess community-level dependence on forest resources, wild products, non-priced goods, or forest services. They are even less likely to evaluate cultural impacts and social costs borne by the local communities when confronted with change and a need to adapt. The assessment of such community costs may be an inefficient, if not impossible task. However, it is not impossible to structure economic development projects that incorporate a more diverse range of economic activities, some of which are not exportfocused; that seek to stabilize community cohesion and age- and gender-based activities, especially for women and youth; that consider and incorporate dietary regimes and nutritional adequacy; and which provide incentives for forest maintenance, and even expansion of forest, with indigenous species.

The shift of the burden of protein production from the forest to the sea in the KCA reflects a disciplinary divide between terrestrial and marine resource managers that could pose food security and sustainability problems. As forest loss has occurred, and fish have been substituted for a range of former protein sources, pressure on the marine resource has increased. Land-based project designs are unlikely to evaluate the impact of their development strategy on the marine 
resource. But incorporation of that potential burden into development projects that alter landscapes, particularly forested ones near the coast, would more accurately reflect their environmental, cultural, and social costs. As loss of forest occurs, whether through expansion of commercialized agriculture, prohibition of harvest from protected areas, or depletion of resources from non-reserved forest patches, communities throughout Ghana will become increasingly marine-dependent.

To their credit, organizations and agencies working with villages in and around KCA have recognized many village-level risks associated with the tourism development project, and have sought to provide alternatives through projects such as snail-rearing, grasscutter farming, villagebased tours, support to performing arts groups, organic cocoa cultivation, and other product development activities. Furthermore, project structures that direct revenue flows to the local level have been proposed, with portions of receipts from visitation to be allocated to support park administration and local communities. Not only did visitation at Kakum increase from 0 to 75,000 per year in a 5-year period, but over half of the visitors were Ghanaian, representing a budding national tourism market that was not anticipated at the outset of the project. The numbers of visitors and stratified (national and international) markets for tourism offer income generation potential for local residents, and biological diversity within the park has been relieved of intense harvest pressure. Other forest values, however, are difficult to integrate and preserve, particularly in a single forest surrounded by a growing human population.

In the long run, maintenance of biological diversity, cultural identity, and the social safety net for forest-related communities seems unlikely to be successful unless forest growth and restoration occur beyond the borders of reserves. The expanded forest would, ideally, link recently-isolated forest remnants and provide a range of traditional goods and services to human communities. Such a landscape-level vision, based on international economic development support, is community-focused, and intended to balance a heretofore conventional development emphasis on exports that has reduced non-export goods and services throughout the forest zone of Ghana. KCA residents may simply adapt to life without a forested landscape, as have other communities in the region. However, the loss of most forest resources leaves large numbers of Ghanaian 
villagers exposed to increased risk with fewer alternatives in the event of global economic or climatic crises. The current prevalence of cocoa, though inadequate as a substitute for intact natural forest, may provide some continuity with limited forest values and resources as long as cultivation practices continue to incorporate indigenous species for shade. Financial incentives from a "conservation reserve"-type program for local communities to support land-use reversion to forest in key areas would help reconstruct a social safety net that has frayed. 


\section{LITERATURE CITED}

Amanor, Kojo Sebastian. 1994. Ecological knowledge and the regional economy: Environmental management in the Asesewa District of Ghana.

Asibey, Emmanuel O.A. 1974. Wildlife as a source of protein in Africa south of the Sahara. Biological Conservation 6(1):32-39.

Asibey, Emmanuel O.A. and Christopher Y. A. Beeko. 1989. The non-timber forest products in Ghana. Symposium on Ghana forest policy, 3-7 April. Accra, Ghana.

Bailey, Brent. 1995. Non-timber forest products and conservation: an assessment from the Kakum Conservation Area, Ghana. Unpublished report. Conservation International, Washington, D.C.

Bailey, Brent and Kojo Mbir. 1997. Non-timber forest products and conservation strategies. In Bailey, Brent (ed.). Facing the storm: Five years of research in and around Kakum National Park, Ghana. Unpublished proceedings of a Research Colloquium. Conservation International, Washington, D.C.

Barnes, R. F. W., S. Azika and B. Asamoah-Boateng. 1995. Timber, cocoa, and crop-raiding elephants: A preliminary study from southern Ghana. Pachyderm 19:33-38.

Decher, Jan. 1997. Conservation, small mammals, and the future of scared groves in West Africa. Biodiversity and Conservation 6:1007-1026.

Dei, George J. S. 1988. Crisis and adaptation in a Ghanaian forest community. Anthropological Quarterly 61:63-72.

Dei, George J. S. 1989. Hunting and gathering in a Ghanaian rain forest community. Ecology of Food and Nutrition 22(3):225-244.

Dei, George J. S. 1990. The changing land use and allocation patterns of a West African community. Africa Development 15:25-44.

Dei, George J. S. 1992. A forest beyond the trees: Tree cutting in rural Ghana. Human Ecology 20(1):57-88.

Dei, George J. Sefa. 1994. The women of a Ghanaian village: A study of social change. African Studies Review 37(2):121-145.

Dickinson, Bryan. 1996. Reconnaissance survey of large mammal distribution and abundance in Kakum National Park, Ghana. Unpublished report. Conservation International, Washington, D.C. 
Dorm-Adzobu, C., O. Ampadu-Agyei, and P.G. Veit. 1991. Religious beliefs and environmental protection: The Malshegu sacred grove in northern Ghana. Washington, D.C.: World Resources Institute, and Nairobi, Kenya: Acts Press.

Faculty of Architecture, University of Science and Technology, Kumasi, Ghana. 1978. Traditional forms of architecture in Ghana. International Social Science Journal 30(3):449-476.

Falconer, Julia. 1992. Non-timber forest products in southern Ghana: A summary report. ODA Forestry Series No. 2. Unpublished report.

Falconer, Julia, and J.E.M. Arnold. 1991. Household food security and forestry. FAO Community Forestry Note 1. Rome.

FAO. 1990. The major significance of 'minor' forest products: the local use and value of forests in the West Africa humid forest zone. Community Forestry Note 6. Prepared by Julia Falconer; edited by Carla R.S. Koppell. Rome.

FAO. 1993. Forest resources assessment 1990: Tropical countries. FAO Forestry Paper 112. Rome.

Glass, Ronald J. and Robert M. Muth. 1989. The changing role of subsistence in rural Alaska. Transactions of the 54th North American Wildlife and Natural Resource Conference.

Gornitz, V. and NASA. 1985. A survey of anthropogenic vegetation changes in West Africa during the last century - climatic implications. Climatic Change 7:285-325.

Hill, Polly. 1986. Development economics on trial: The anthropological case for a prosecution. Cambridge University Press. Cambridge, U.K.

Kpelle, David G. 1993. Evaluation of past management and resource use of Kakum and Assin Attandanso forest reserves. Unpublished report, Department of Game and Wildife, Accra.

Lewis, Ronald L. 1993. Appalachian restructuring in historical perspective: Coal, culture and social change in West Virginia. Urban Studies 30(2):299-308.

Martin, Claude. 1991. The rainforests of West Africa. Birkhauser Verlag, Basel.

Mills, Bradford F. 1994. Public finance and public employment: an analysis of public sector retrenchment programs in Ghana and Guinea. Cornell Food and Nutrition Policy Program. Ithaca, New York. 
Ntiamoa-Baidu, Yaa. 1992. Local perceptions and value of wildlife reserves to communities in the vicinity of forest national parks in western Ghana. Appendix 1 in: Protected area development in south-west Ghana, Final Report. Environment and Development Group. Oxford, U.K.

Ntiamoa-Baidu, Yaa. 1997. Wildlife and food security in Africa. FAO Conservation Guide \#33. Rome.

Omohundro, John T. 1985. Efficiency, sufficiency, and recent change in Newfoundland subsistence horticulture. Human Ecology 13(3):291-308.

Patton, Michael Quinn. 1990. Qualitative evaluation and research methods. 2nd Edition. Sage Publications. Newbury Park, California.

Schrage, Reinhard and Lississi Togbe Yewadan. 1992. Grass-cutter production: Achievements and prospects. 1st International Conference Proceedings. Cotonou, Benin. Unpublished report.

Struhsaker, Thomas T. 1993. Ghana's forests and primates. Report of a field trip to Bia and Kakum National Parks and Boabeng-Fiema monkey sanctuary in November 1993. Conservation International. Unpublished report.

Struhsaker, Thomas T., Jeremiah S. Lwanga, and John M. Kasenene. 1996. Elephants, selective logging and forest regeneration in the Kibale Forest, Uganda. Journal of Tropical Ecology 12:45-64.

The Cocoa Sector. 1983. Backgroupnd paper No. 1 of 4. Prepared for the Ghana Policies and Programme for Adjustment Report, No. 4702-GH, issued on October 3, 1983. Working Paper of Western Africa Programmes Department I, Division B.

Tripp, Robert. 1992. Dietary consequences of changes in trade and agriculture for the Nankane of northern Ghana. Ecology of Food and Nutrition. 27:249-258.

Wagner, Michael R. and Joseph R. Cobbinah. 1993. Deforestation and sustainability in Ghana. Journal of Forestry 91(16):35-39. 
Appendix 4-A

Pre-Survey Data Sheet

NON-TIMBER FOREST PRODUCTS

University of Cape Coast

Interviewer:

Date:

B.P.No.

Community name:

Respondent:

Estimated distance from Reserve boundary to community: mi

Measured distance from previous community: miles

Number of people in community:

Number of houses: Avg number of people per house:

Number of households per house:

Date of community establishment: (year)

Types of social amenities (yes or no):

Schools: primary JSS If none, where is nearest (name)?

Distance:

Health clinic: If none, where is nearest? Distance:

Water: stream $\mathrm{BH}$ well

Market: If none, where is nearest? Distance:

Nearest road (distance):

Other 
Economic activities (rank):

$$
\begin{aligned}
& \text { farming } \\
& \text { hunting } \\
& \text { ___ gathering } \\
& \text { crafts }
\end{aligned}
$$
others:

Days for community work:

Next community toward market (name): 


\section{Appendix 4-B}

NON-TIMBER FOREST PRODUCTS STUDY

\section{University of Cape Coast}

Code for household

Date of interview:

Interviewer(s):

Time begin: Recorder:

\section{MARKET ACCESS}

1. What market(s) do you go to?

2. What is the distance to the market(s)?

3. How long does it take you to get to the market(s)?

4. What is your means of transport there?

5. How often do you go to the market(s)? per

6. What, if anything, do you sell at the market?

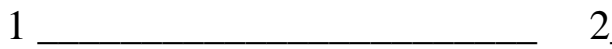

7. What food do you buy at the market?

1 2 3

8. What other goods do you buy at the market?

1 2 3

9. What percentage of the food items consumed by your household is purchased at the market? $\%$

10. What meals have been prepared in the household in the past 3days?

1 2

3 4

11. What other foods and snacks have household members eaten and drunk in the past 3 days?

1 2

3 4 
Code:

12. What are your protein sources?

\begin{tabular}{||c|c||}
\hline \hline Types & Source \\
\hline & \\
\hline & \\
\hline & \\
\hline & \\
\hline
\end{tabular}

13. What kinds of meat do you prefer (rank)?

1 2 3

\section{HEALTH}

14. Now I'd like to ask you about how you care for your health.

\begin{tabular}{||l|l|l|l||}
\hline $\begin{array}{c}\text { Recent HH illness, inj., } \\
\text { or ailment }\end{array}$ & How treated? & $\begin{array}{c}\text { Homemade } \\
\text { remedies? Y/N }\end{array}$ & $\begin{array}{c}\text { Source of mat'ls or } \\
\text { remedies }\end{array}$ \\
\hline & & & \\
\hline & & & \\
\hline & & & \\
\hline & & & \\
\hline & & & \\
\hline & & & \\
\hline
\end{tabular}

15. Do you visit a native doctor at times? 1_ Yes $2 \_$No

16. If you use herbal remedies, how do you acquire them? (more than one may apply)

$1 \ldots$ purchase from native doctors 2 __ purchase from market

$3 \ldots$ _ purchase from friends/neighbors $4 \_$_ make at home

5 __other

17. How many times have members of your household gone to a clinic in the past year? 
Code:

\section{LAND}

18. If you farm, how much land do you have? acres/poles/hectares/arms'length (circle unit)

19. How much of the land that you oversee is:

1 family land?

2 owned?

3 leased? specify: (fraction)

4 rented out?

20. If you wanted to farm more land, would it be available locally?

$1 \_$Yes $2 \_$No

21. If you farm, do you produce enough food to feed your family?

$1 \_$Yes 2_ No

22. If no, where do you get the rest?

23. Now, some information about the farming activities you pursue:

\begin{tabular}{||l|l|l|l|l||}
\hline \hline Type of activity & $\begin{array}{c}\text { Acreage } \\
\text { (acres) }\end{array}$ & $\begin{array}{c}\text { Yield/acre or } \\
\text { remuneration }\end{array}$ & Sale price & $\begin{array}{c}\text { Animal } \\
\text { damage? } \\
\text { (type) }\end{array}$ \\
\hline & & & & \\
\hline & & & & \\
\hline & & & & \\
\hline & & & & \\
\hline & & & & \\
\hline
\end{tabular}

24. Are you able to protect your crops from animal damage? 1__ Yes $2 \_$No 25. If yes, how? 
Code:

26. If no, why not?

27. If you won fifty million cedis, what would you do with it?

28. Would you move elsewhere to live if you were compensated for your land or offered a similar job? 1__ Yes 2_ No

29. Are you employed by someone? 1__ Yes 2_No

30. If yes, what do you do for that person?

31. Do you employ others? $1 \_$Yes 2_No

32. If yes, what do they do for you?

33. Now I'd like to know about animals you keep (fill table).

\begin{tabular}{||c|c|c|c|c|c||}
\hline Type & No. kept & $\begin{array}{c}\text { Use } \\
(\mathrm{P}, \mathrm{S}, \mathrm{E}, \mathrm{O})\end{array}$ & $\begin{array}{c}\text { Cost of } \\
\text { food }\end{array}$ & Sale price & \\
\hline & & & & & \\
\hline & & & & & \\
\hline & & & & & \\
\hline
\end{tabular}

34. Fuel:

\begin{tabular}{||c|c|c||}
\hline \hline Type & Used for? & Source \\
\hline & & \\
\hline & & \\
\hline & & \\
\hline
\end{tabular}

\section{TIME ALLOCATION}

FOR HH HEAD:

35 . How have you spent your time in the last 24 hours?

1

3
2

4 
Code:

36. How does your schedule change throughout the year (on and off season times)?

2

3

4

37. How do you generally spend your time (\%)?

$1 \ldots$ Farming

2 __ Hunting

3 _ Gathering

4 Relaxing

5 __ Other

\section{Household Data: Economic}

The next set of questions asks about your expenses and income.

38. Please estimate the following expenses for the household:

\begin{tabular}{||l|l|l||}
\hline \multicolumn{1}{|c|}{ Expense } & $\begin{array}{c}\text { Amount per } \\
\text { wk?/mo?/qtr?/yr? }\end{array}$ & Annual estimate \\
\hline Development levies & & \\
\hline Funerals & & \\
\hline Allowances & & \\
\hline Remittances & & \\
\hline Schools & & \\
\hline HH goods & & \\
\hline Farm equip & & \\
\hline Pesticides & & \\
\hline Fertilizers & & \\
\hline Clothes & & \\
\hline Transport & & \\
\hline
\end{tabular}


Code:

\begin{tabular}{||l|l|l||}
\hline Health & & \\
\hline Rent (incl. land tenure arrngmt) & & \\
\hline Labor & & \\
\hline Fuel - firewood & & \\
\hline Fuel - kerosene & & \\
\hline Fuel - petrol & & \\
\hline & & \\
\hline
\end{tabular}

\section{SOURCES OF INCOME}

FOR HH HEAD:

39. What is your primary occupation?

40. If cocoa, what variety is planted? 1_ Tetteh Quarshie 2_ Agric 3_ Hybrid

41. What is your secondary occupation, or what do you do to earn money when you aren't working at your primary occupation?

FOR 2nd IN COMMAND IN HH:

42. What is your primary occupation?

43. What is your secondary occupation, or what do you do to earn money when you aren't working at your primary occupation?

FOR THE HH IN GENERAL:

44. Do you have income from sources other than your primary and secondary occupations?

$1 \_$Yes 2__ No

45. If yes, what are they?

$1 \_$Remittances by absentees Amount:

2 Rents Amount:

3 Other

Amount:

Amount:

Amount: 
Code:

46. Five years ago, were your occupations different from the ones you have now?

$1 \_$Y Yes 2_ No

47. If yes, what were they?

48. Do you earn more or less now than before? $1 \_$More $2 \_$Less

\section{HOUSEHOLD DATA - PERCEPTIONS}

In this section of questions, I'd like to ask you for your opinions about forest reserves, wildlife, and wild plants.

49. Do you think that forest reserves, wild animals, and wild plants offer benefits, disadvantages, both benefits and disadvantages, or neither, to people?

1a ___ Yes, benefits

$1 b$ ___ Yes, disadvantages

1c ___ Yes, both benefits and disadvantages

2 __ No, neither benefits nor disadvantages

50. If yes, what are they?

\begin{tabular}{||c|c||}
\hline Benefits & Disadvantages \\
\hline & \\
\hline & \\
\hline & \\
\hline & \\
\hline & \\
\hline
\end{tabular}

51. Have you noticed any changes in any of these benefits and disadvantages? $1 \_$Yes $2 \_$No

52. If yes, would you please specify:

\begin{tabular}{||l|l|l||}
\hline \hline Change & When it occurred & Possible Reason \\
\hline & & \\
\hline & & \\
\hline & & \\
\hline & & \\
\hline
\end{tabular}


Code:

\section{FOREST ACCESS}

53. If someone was going to the Kakum forest, how long did it take him to walk there from the community (time)?

54. How far is the forest from the community (distance)?

55. If you farm, how close is your farm to the forest (distance)?

56. Apart from the benefits that members of the community could derive from the reserve, has the reserve helped you or any member of the family in any way? 1_Y Yes 2_No 57. If yes, are there any products that you now buy in the market which used to be available from the forest? 1__ Yes 2_ No

58. If yes, what are they?

1

2.

3.

4.

59. Have prices of some these products changed in the last five years? $1 \_$Yes 2 _ No 60. If yes, please indicate.

\begin{tabular}{|l|l|l|}
\hline \hline Product & Old Price & New Price \\
\hline & & \\
\hline & & \\
\hline & & \\
\hline & & \\
\hline & & \\
\hline \hline
\end{tabular}

61. Before the forest became a Park, were you allowed to go there for some products? $1 \_$Yes 2_No 
Code:

62. What products could you get from the forest? (Fill table for plants and animals).

NON-TIMBER FOREST PRODUCTS: PLANTS

\begin{tabular}{|c|c|c|c|c|c|c|c|}
\hline $\begin{array}{l}\text { Product and/or } \\
\text { species }\end{array}$ & Part used & Use & $\begin{array}{l}\text { Disposition } \\
\text { P,S,E,O* }\end{array}$ & Seasonality & Who collects? & $\begin{array}{l}\text { Substi- } \\
\text { tutes }\end{array}$ & $\begin{array}{l}\text { Cost/ } \\
\text { Unit of } \\
\text { sub }\end{array}$ \\
\hline \multicolumn{8}{|l|}{ Raffia } \\
\hline \multicolumn{8}{|l|}{ Cane } \\
\hline \multicolumn{8}{|l|}{ Sponge } \\
\hline \multicolumn{8}{|l|}{ Pestle } \\
\hline \multicolumn{8}{|l|}{ Mortar } \\
\hline \multicolumn{8}{|l|}{ Chew stick } \\
\hline \multicolumn{8}{|c|}{ Wrapping Leaves } \\
\hline \multicolumn{8}{|c|}{ Mushrooms } \\
\hline \multicolumn{8}{|l|}{ Eshe } \\
\hline \multicolumn{8}{|l|}{ Herbal meds. } \\
\hline & & & & & & & \\
\hline & & & & & & & \\
\hline
\end{tabular}

* - P: Personal Consumption; S: Sale; E: Exchange; O: Other 
Code:

NON-TIMBER FOREST PRODUCTS: ANIMALS

\begin{tabular}{||l|l|l|l|l|l|l|l||}
\hline $\begin{array}{l}\text { Product and/or } \\
\text { species }\end{array}$ & Part used & Use & $\begin{array}{l}\text { Disposition } \\
\text { P,S,E,O* }\end{array}$ & Seasonality & Who collects? & $\begin{array}{l}\text { Substi- } \\
\text { tutes } \\
\text { Unit of } \\
\text { sub }\end{array}$ \\
\hline Grasscutter & & & & & & & \\
\hline Bush Pig & & & & & & & \\
\hline $\begin{array}{l}\text { Monkey } \\
\text { specify) }\end{array}$ & & & & & & & \\
\hline Snail & & & & & & & \\
\hline Bush Rat \\
Duiker \\
(specify)
\end{tabular}

* - P: Personal Consumption; S: Sale; E: Exchange; O: Other 
Code:

63a. Are there any animals or plants you would not exploit for cultural reasons? 1__ Yes 2__ No

$63 \mathrm{~b}$. If yes, what are they?

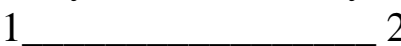
3

63c. How often did you go to the forest before it became a Park (times per week, per month, etc.)?

64. Did you use some means of transport to the forest other than walking? 1_Yes 2_ No 65. If yes, what was it?

66. Are there other patches of forest outside the Reserve where you can get the products that are important to you?

$1 \_$Y Yes 2 __ No

67. If yes, how far are these forests from your home (distance)?

\section{Household Data: General}

68. Village or Hamlet (name):

69. Do you belong to a religion? $1 \ldots$ Yes $2 \_$No

70. If yes, what is it?

$1 \_$Christian 2__ Moslem 3__ Traditional 4 Other

71. If Christian, what denomination is it?

1__ Orthdx 2__ Pentecstl 3_Spirit'1 4 Other

For head of household:

72. Are you a native of this village? $1 \ldots$ Yes $2 \_$No

73. Where were you born? village

region

74. If not born in this village, what year did you arrive?

75. If not born in this village, why did you come here? 
Code:

76. Do you have contact with your native village? $1 \_$Yes $2 \_$No

77. What contact do you have with your home village?

$1 \ldots$ go to visit; when last (mo., yr.)?

$2 \ldots$ send money; when last (mo., yr.)?

3 __ write letters; when last (mo., yr.)?

4

78. What family members are currently living in this household?

(List head of household first, then second in command, then rest)

\begin{tabular}{|c|c|c|c|c|c|}
\hline First name & $\mathrm{M} / \mathrm{F}$ & Age & $\begin{array}{c}\text { Relation to } \\
\text { HH head }\end{array}$ & $\begin{array}{c}\text { Yrs of } \\
\text { school }\end{array}$ & $\begin{array}{l}\text { At intvw? } \\
\text { Y/N } \\
\end{array}$ \\
\hline & & & & & \\
\hline & & & & & \\
\hline & & & & & \\
\hline & & & & & \\
\hline & & & & & \\
\hline & & & & & \\
\hline & & & & & \\
\hline & & & & & \\
\hline & & & & & \\
\hline & & & & & \\
\hline & & & & & \\
\hline & & & & & \\
\hline
\end{tabular}

79. Are there times of the year when some $\mathrm{HH}$ members now living here are away?

$1 \_$Yes $2 \ldots$ No 
Code:

80. If yes, please fill table.

\begin{tabular}{||l|l|l||}
\hline First name & Period when absent & Reason \\
\hline \hline & & \\
\hline & & \\
\hline & & \\
\hline
\end{tabular}

81. Are there some members of the $\mathrm{HH}$ who are not living here now? 1 __ Yes 2 _ No

82. If yes, please fill in the following table:

\begin{tabular}{||l|l|l|l|l||}
\hline \hline First name & Rel. to HH/H & Where now? & Away for what? & $\begin{array}{l}\text { Freq. of visits } \\
\text { home }\end{array}$ \\
\hline & & & & \\
\hline & & & & \\
\hline & & & & \\
\hline & & & & \\
\hline & & & & \\
\hline
\end{tabular}

\section{Household Data - Natural Resources}

83. In the past did you depend on products from the reserve?

$$
1 \_ \text {Yes } 2 \text { ___ No }
$$

84. If yes, how often did you go there?

$$
\begin{aligned}
& 1 \_ \text {daily } \\
& 2 \_ \text {once every other day } \\
& 3 \_ \text {weekly } \\
& 4 \_ \text {certain seasons (specify) } \\
& 5 \_ \text {other (specify) }
\end{aligned}
$$

85. What is your source of drinking water?

$1 \_$BH 2__ dugout 3_spring 4_stream/river 5_other

86. If the source is a stream/river, is it located in the Reserve? $1 \_$Yes 2 _ No 
Code:

87. What goods or services from the Reserve should villagers have access to?

1 2

3

4

88. Do you see any need for protection of

Forests? 1__Yes 2_No

Wild animals? 1__Yes 2_No

Wild plants? 1__Yes 2_No

89. If yes, why?

$1 \_$To protect water supplies

2__ To maintain wildlife

3 __ To produce medicines

4 __ To maintain balance of nature

5 __ Other (specify)

90. What would happen to the forest if the Reserve were just opened up, and the government left?

91. Who should be responsible for protection?

$1 \_$Government

2 __ Community

3__ Government and community together

4 __ Other (specify) 
Code:

92. How could this be done?

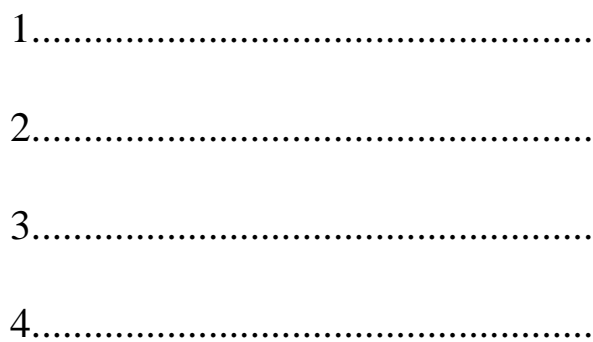

93. What suggestions do you have to promote a cordial relationship between the community and Game and Wildlife?

1

2.

3.

94. Do most families use the Reserve in some way? $1 \_$Yes $2 \_$No

95. If yes, how?

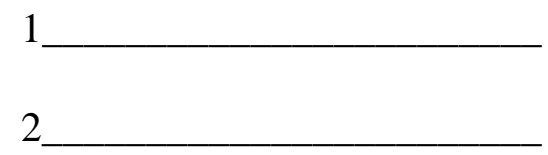

96. Do you now visit the Reserve? 1__ Yes 2_No

97. What kinds of bush meat do you prefer (rank)?

1.

2.

3.

4.

98. Do you have any questions or comments?

Thank you. 


\section{BRENT BAILEY}

906 Rawley Ave.

Morgantown, W.V. 26505

tel: 304-598-9403 (h); 304-293-2941, ext. 2475 (w); email: bbailey@wvu.edu

\section{PROFESSIONAL EXPERIENCE}

Conservation International, Washington, D.C. (co-founder, 1987-present)

Technical Director, West Africa Program (1992-present; part time): Oversee development and implementation of training, research, and community development projects in West Africa.

Previous Projects at CI:

Managed Rapid Assessment Program (1989-1992) for CI Science Department, designed to identify areas of high biological value for conservation, primarily in tropical areas around the globe. Coordinated a core team of biologists and collaborative agreement with foreign institutions (universities, museums).

Developed of a program of technical support for conservation planning in the Petén wilderness of Guatemala.

The Nature Conservancy International Program, Washington, D.C. (1985-1987)

Coordinator of Conservation Data Center Operations: Assessed and administered operational support to Latin American Conservation Data Centers, charged with developing and maintaining databases on flora, fauna, and protected areas.

Manomet Bird Observatory, Manomet, Massachusetts (1983)

Field Research Assistant: Coordinated censuses of breeding bird populations; vegetation sampling; supervised intern staff.

Mountwood Park, West Virginia (1978-1981)

Staff Manager, White Oak Village (1981): Supervised programming staff during startup of recreational facility for the handicapped; designed and administered programs; coordinated staff training and public access to park and recreational facilities.

Park Naturalist (1978-1981) Developed and administered operations of a new nature center; recruited and trained volunteers; designed education and outreach programs. 


\section{EDUCATION}

West Virginia University (1992-1999)

Ph.D., Forest Resource Science

Dissertation: Social and economic impacts of Wild Harvested Products

Teaching assistant: Wildlife Habitat Techniques, non-game species unit

Coordinator: "Engaging, Empowering, and Negotiating Community: Strategies for Conservation and Development" workshop with Conservation Development Forum of University of Florida

\section{Yale School of Forestry and Environmental Studies}

Master of Environmental Studies, 1985

Teaching assistant: Introductory undergraduate natural resource issues course

University of Yaounde, Cameroon, West Africa

Rotary Foundation Graduate Scholar, Zoology, 1981-82

Course work in ornithology and ecology

Kalamazoo College, Kalamazoo, Michigan

B.A., majors in biology and French

Senior project in shorebird ecology

University of Neuchatel, Switzerland

Certificate in French language and literature

\section{PUBLICATIONS}

Parker, Theodore A. III and Brent Bailey (eds.). 1991. A biological assessment of the Alto Madidi region (Bolivia). Rapid Assessment Program Working Papers 1. Conservation International, Washington, D.C.

Bailey, Brent. 1995. Non-timber forest products and conservation: an assessment from the Kakum Conservation Area, Ghana. Report for U.S. Agency for International Development, Ghana. Conservation International, Washington, D.C.

Bailey, Brent (ed.). 1997. Facing the Storm: Proceedings of the Kakum Conservation Area Research Colloquium, January 9-12, 1996. Conservation International, Washington, D.C. 


\section{SKILLS, ACTIVITIES}

French and Spanish (professionally fluent); Italian (functional)

Bird watching, sourdough baking, gardening

Board member, West Virginia Land Trust

\section{PERSONAL}

Date of birth: 7 April 1955, Parkersburg, West Virginia

Married, two children 